\title{
PRODUCTION OF BIOPLASTICS FROM RENEWABLE AND SUSTAINABLE FEEDSTOCK RESOURCES \\ by
}

\begin{abstract}
AHMAD CHAUDHRY
MSc in the study of Analytical Chemistry

University of Huddersfield, Huddersfield, UK, 2016

$\&$
\end{abstract}

BSc (Honours) in the study of Pharmacy and Pharmaceutical Studies

Medway School of Pharmacy, Gillingham-Chatham, UK, 2015

\author{
A Master's Research Project \\ presented to Ryerson University \\ in partial fulfilment of the \\ requirements for the degree of \\ Master of Engineering \\ in the program of \\ Chemical Engineering
}

Toronto, Ontario, Canada, 2018

(C) Ahmad Chaudhry, 2018 


\section{Author's Declaration}

I hereby declare that I am the sole author of this MRP. This is a true copy of the MRP, including any required final revisions.

I authorize Ryerson University to lend this MRP to other institutions or individuals for the purpose of scholarly research.

I further authorize Ryerson University to reproduce this MRP by photocopying or by other means, in total or in part, at the request of other institutions or individuals for the purpose of scholarly research.

I understand that my MRP may be made electronically available to the public. 


\begin{abstract}
Production of Bioplastics from Renewable and Sustainable Feedstock Resources

Master of Engineering, 2018

Ahmad Chaudhry

Chemical Engineering

Ryerson University

This study illustrates the potential opportunity for the utilization of hemp to produce PHB (poly(3-hydroxybutyrate). The objective of the study was to optimize simple sugar availability from hemp for Ralstonia eutropha. The use of three pre-treatment methods (grinded $-5 \% \mathrm{NaOH}$ - Autoclave at $121{ }^{\circ} \mathrm{C}$ for 60 minutes) was able to provide a better fractional insoluble solids (FIS) of $\simeq 61 \%$ that was significantly better compared to other combinations of pre-treatments studied. Optimum enzyme dosage was also determined by comparing different enzyme concentrations and found that three enzymes should contain a dose of $1.5 \mathrm{~g} / \mathrm{L}$. The optimum pretreatment and hydrolysis conditions resulted in a better enzyme hydrolysis yield of $10.9 \%$ and PHB yield of $\simeq 43 \%$. Results also demonstrate that sonification did not improve PHB recovery, while pH control increased PHB recovery.
\end{abstract}

Keywords: Hemp, Ralstonia eutropha, PHB, Pre-treatment, Enzyme Hydrolysis 


\section{Acknowledgments}

Firstly, I would like to acknowledge my research supervisor, Professor Yaser Dahman,

for providing me the opportunity to be part of his research group. Your continuous support and guidance throughout my career at Ryerson University is greatly appreciated.

I would also like to acknowledge Mohamed Khattab, for his valuable suggestions and insight. They were greatly valued. 


\section{Table of Contents}

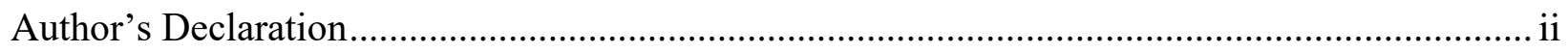

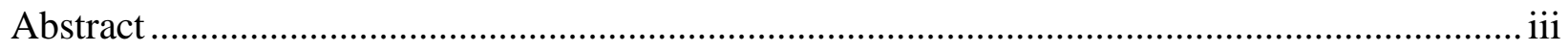

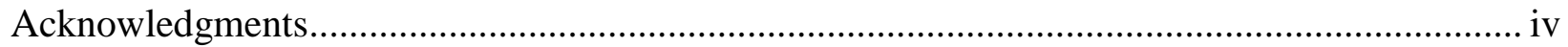

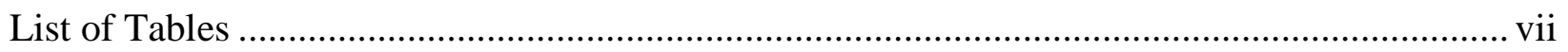

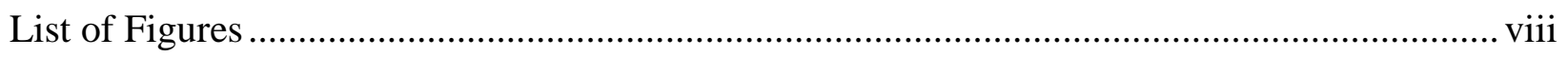

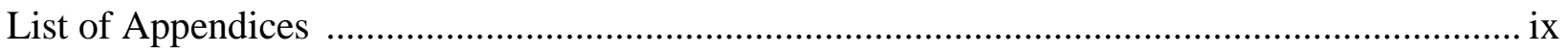

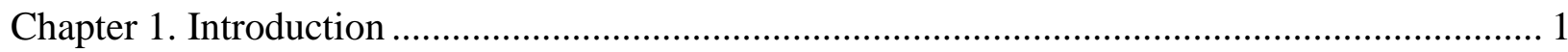

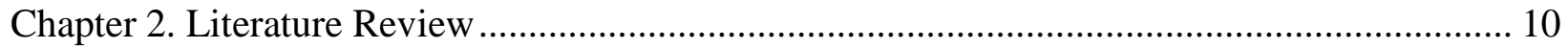

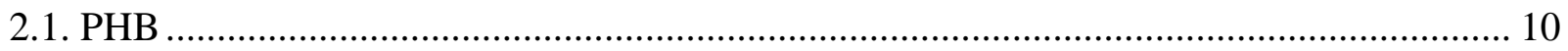

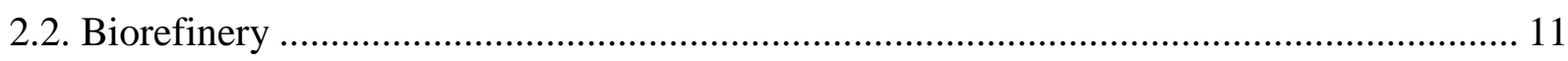

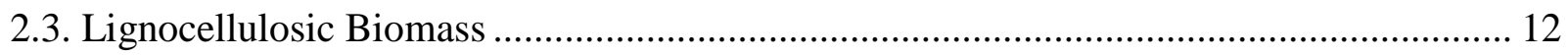

2.4. Other Biomass Considered...................................................................................... 13

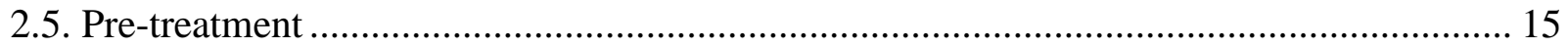

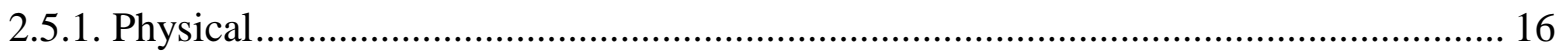

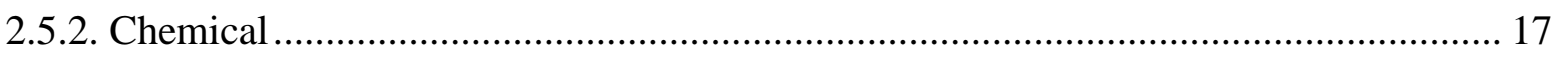

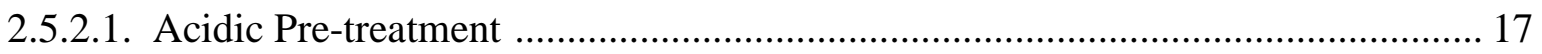

2.5.2.2. Alkalization Pre-treatment …………………….......................................... 18

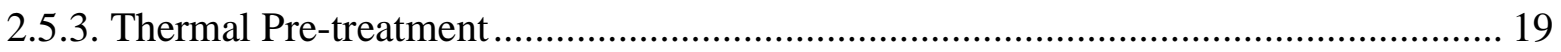

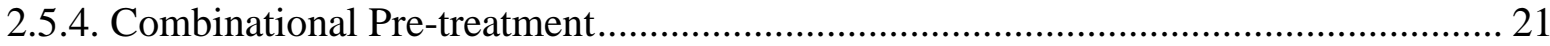

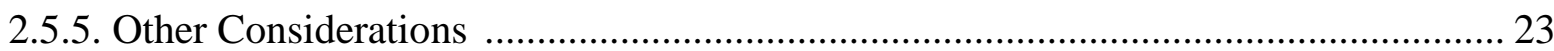

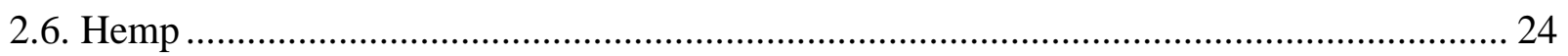

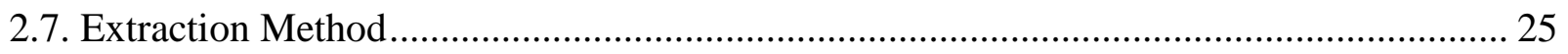

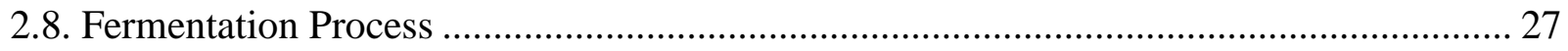

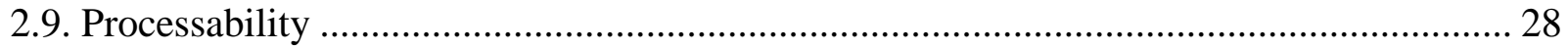

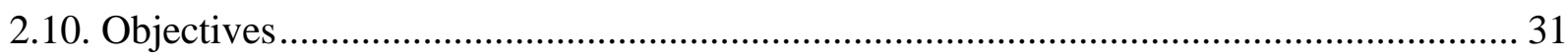

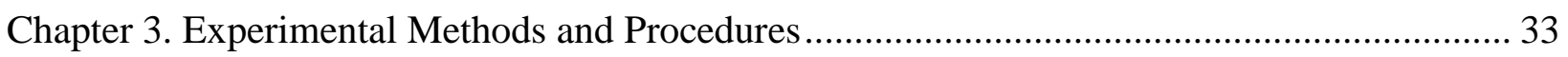

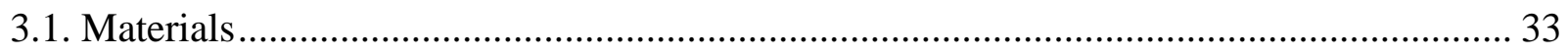

3.2. Hemp Biomass Pre-treatment \& Enzyme Hydolysis .......................................................... 34

3.2.1. Hemp Physical Pre-treatment ........................................................................... 34

3.2.2. Hemp Alkalization \& Thermal Pre-Treatment .......................................................... 35

3.2.2.1. Pre-Treatment Quality Control …………………………………………….... 35 


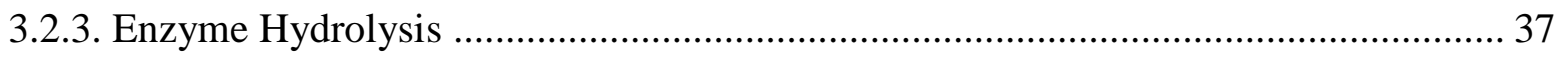

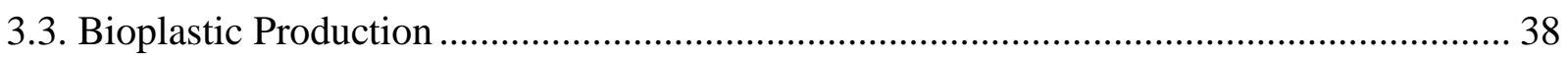

3.3.1. Ralstonia eutropha activation................................................................................. 38

3.3.2. Ralstonia eutropha addition ................................................................................... 39

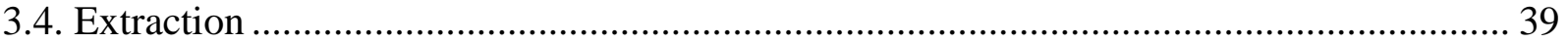

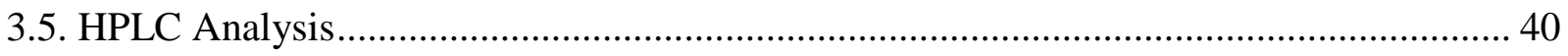

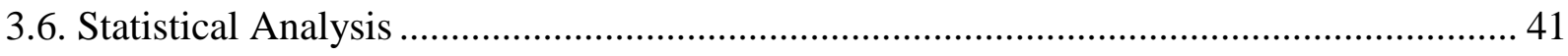

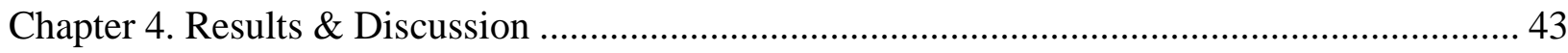

4.1. Pre-treatment Effectiveness......................................................................................... 43

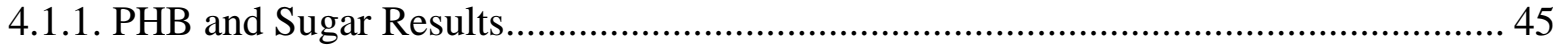

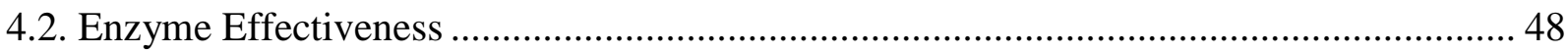

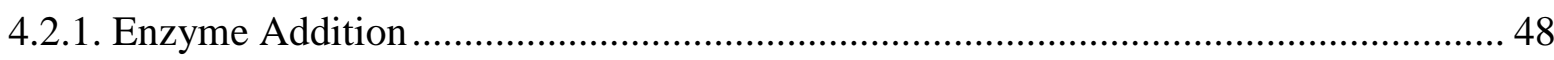

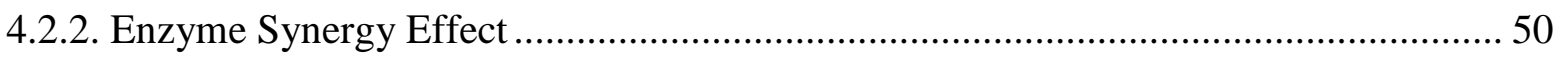

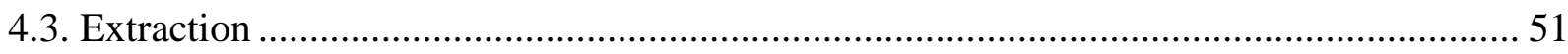

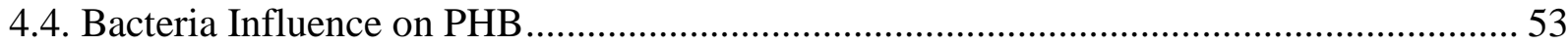

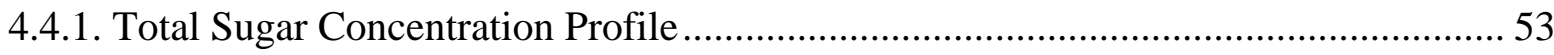

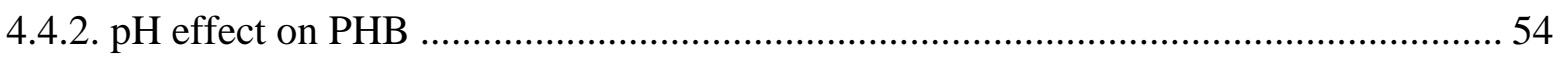

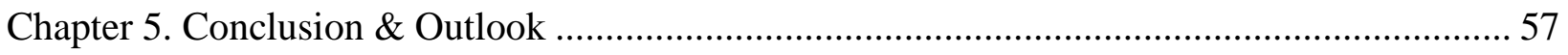

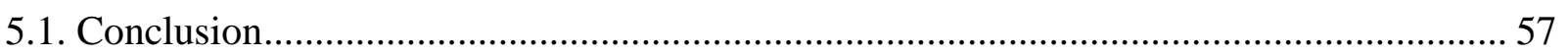

5.2. Outlook and Future Recommendations ......................................................................... 58

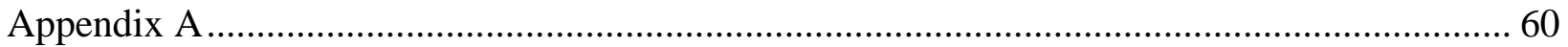

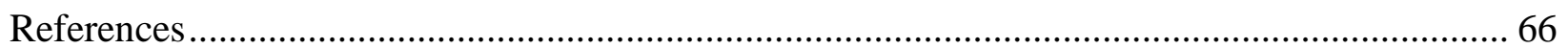




\section{List of Tables}

Table 1.1 Compares PHA polymer characteristics with fossil-fuelled based plastics.................. 8

Table 2.1 Summarizes the cellulose, hemicellulose and lignin content within different biomass 14 Table 2.2 List of agriculture waste in relation to the production of cell dry weight (CDW) and

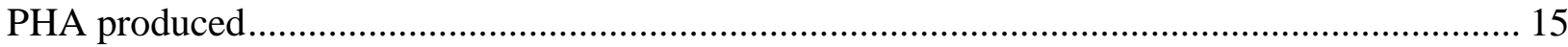

Table 2.3 Compares Physical, chemical, thermal pre-treatments ......................................... 20

Table 2.4 Summarizes the different biomass and corresponding pre-treatment comparing

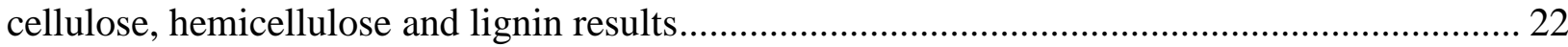

Table 2.5 Compares different PHB extraction methods ......................................................... 26

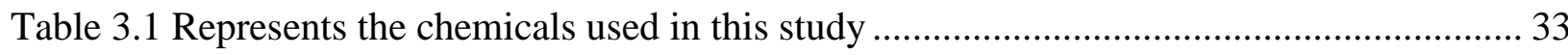

Table 3.2 Represents the enzymes used in this study ....................................................... 34

Table 3.3 Represents the sample of Pre-treated hemp studied followed by Enzyme Addition

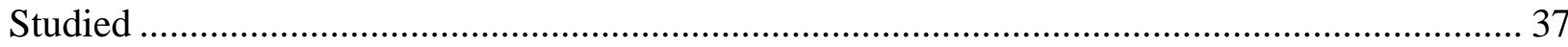

Table 4.1 Summarizes results for FIS obtained fo different pre-treatment followed Table 3.3 ... 44 Table 4.2 Summarizes results for the sugar concentration before and after fermentation followed Table 3.3 


\section{List of Figures}

Figure 1.1 Illustrates the chemical formula for PHB. .................................................... 9

Figure 2.1 Represents $\mathrm{NaOH}$ interaction with Hemp bast fibers .............................................. 19

Figure 2.2 Illustrates countries that are currently producing hemp ...................................... 25

Figure 2.3 Summarizes bioreactors categories and features. ............................................. 28

Figure 4.1 Represents the pre-treatment effect on hydrolysis yield, PHB recovery and FIS ...... 46

Figure 4.2 Represents the cellulase-T.ressi concentration effect in relation to hydrolysis recovery

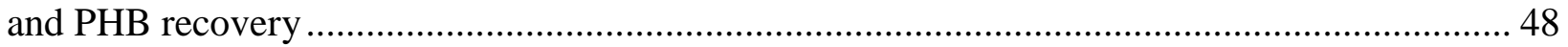

Figure 4.3 Represents the effect from enzyme addition in relation to hydrolysis yield and PHB

recovery......

Figure 4.4 Represents extraction with/ without Sonification in relation to hydrolysis yield and

PHB recovery

Figure 4.5 Represents the total sugar concentration profile using the separate hydrolysis and

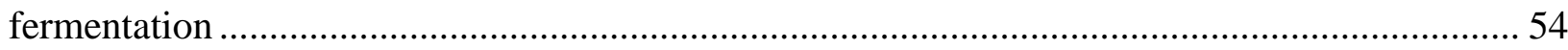

Figure 4.6 Represents the $\mathrm{pH}$ outcome on PHB production optimal conditions (Batch 7) .......... 56 


\section{List of Appendices}

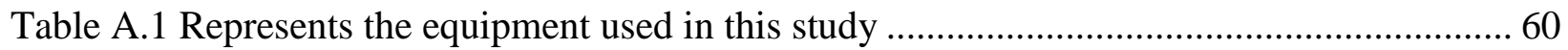

Figure A.1 Glucose Calibration Curve for known concentrations ........................................................ 61

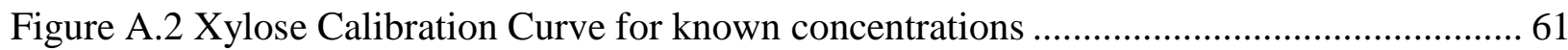

Table A.2 Shows FIS observations and corresponding average and standard deviation............... 62

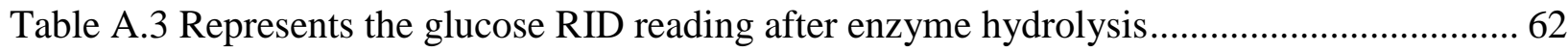

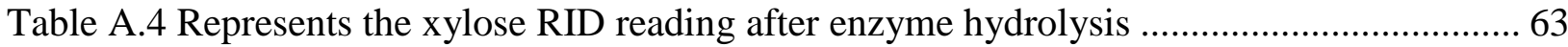

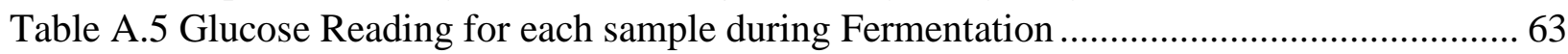

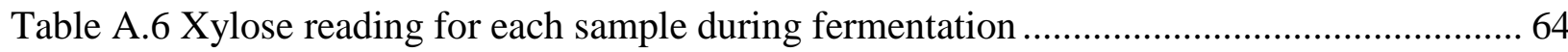

Table A.7 Represents wet mass produced and corresponding average and standard deviation ... 64

Table A.8 Represents AC1 $\mathrm{pH}$ reading and corresponding average and standard deviation ........ 65

Table A.9 Represents AC7 pH reading and corresponding average and standard deviation ........ 65 


\section{Chapter 1 \\ Introduction}

Plastics are found everywhere, in homes, industry, and in different medicinal applications. They are inexpensive, durable material suitable for a wide variety of applications used by consumers on a daily basis (Cai et al. 2018). Plastics dominate the packaging industry and have seen exponential growth globally by shifting the use of plastics from reusable to singleuse applications (Geyer et al. 2017). For example, plastic bags have become known as an effective single-use product (Geyer et al. 2017; Alam et al. 2018). Among consumers and commercial retailers, plastic bags have become recognized for its functionality, lightweight, and economically low-cost method of transporting goods and materials. As a result, the global plastic production is growing on a daily basis (Alam et al. 2018). Plastics Europe reported that the world produced 335 million tons of plastic in 2016 (PlasticEurope, 2018).

Plastics are manufactured from fossil hydrocarbons containing ethylene and propylene, making them nondegradable (Geyer et al. 2017). Nondegradable plastic is defined as the ones that exhibit "lack of ability of the material to decompose or mineralize at measurable rates" (Leslie, 2015). At present, plastic is the most common pollutant on the planet displaying serious ecological and economic issues (Avery-Gomm et al. 2018). For example, plastic bags have a problematic short life cycle, and after use plastic bags are generally thrown away after 20 minutes and in certain settings can be utilized up to a maximum of one year. With large amounts of plastic products being disposed (regulated and dumped illegally), this has led to adverse environmental events (land, air, water resources) and public health issues (Alam et al. 2018). 
Generally, increase production of plastic production and short-term use of plastics being discarded, eventually reach landfills, incinerators or in the natural environment (legally or illegally) (Breyer et al. 2017; Geyer et al. 2017; Alam et al. 2018). Plastics are not biodegradable resulting in growing concern over its accumulation and its effects (Geyer et al. 2017). Petroleumbased plastics only decompose through combustion or other forms of thermal reactions (Geyer et al. 2017). Within landfills, heavy metals used in plastics do not degrade. The expected residual time of heavy metals is approximately 150 years (Adelopo et al. 2018). As heavy metals leach out, landfill plastic pollution contribute to as sources of contamination for freshwater and air (contributing to greenhouse gases) (Beyer et al. 2017).

Soil is a big part of urban ecosystems. Due to industrialization, urbanization, and advancements in agriculture, toxic plastic pollutant accumulates in the soil and act as a reservoir (Wang et al. 2018). This pollutant can migrate to the surface to the topsoil or migrate to groundwater and precipitate, then released into the environment via volatilization affecting both the atmosphere and different water sources (Wang et al. 2018). Plastic waste is found throughout the world's water supply. It was reported that more than 12.7 million tons of plastic waste, have already enter the ocean (Jambeck et al. 2015; Bour et al. 2018). Plastic waste is expected to grow in the following years as shipping, fishing, tourism, and other transport activities increase over time (Colmenero et al. 2017). Within the ocean, the plastic waste is exposed to different physical, biological and chemical processes/reactions that result in continuous fragmentation into micro-sized particles known as microplastics (Choi et al. 2018). Microplastics are characterized as being less than $5 \mathrm{~mm}$ (Bour et al. 2018).

As fragmentation process continues, the concentration of microplastic is expected to increase in the environment over time (Cai et al. 2018). In certain parts of the aquatic 
environment, maximum microplastic concentration reached up to 100,000 particles / $\mathrm{m}^{3}$ (Choi et al. 2018). The high concentration of microplastics has led to several different problems in the marine ecosystem. Particular threats to the marine ecosystem include the digestion of microplastics in different marine environments (Colmenero et al. 2017). The small size of microplastics can simply be transported to other water sources (seas, lakes, rivers, etc), by ocean currents, wind, tides etc. (Cai et al. 2018). Due to the size of microplastics resembling the plankton species, microplastics can be easily confused by invertebrates and other fish species (Ding et al. 2017).

It was reported in 2015 by de Sá, who investigated the effect of microplastic on juvenile goby that goby had difficulty differentiated between microplastic and its prey (de Sá et al. 2015). Other research such as the one conducted by Ding et al. (2017) focused on the ingestion of microplastics with zebrafish and found microplastic accumulation in different parts of the zebrafish including gills, brain, gut, and liver (Ding et al. 2017). Furthermore, a study completed in 2017 by Jovanović, found that fish that accumulate microplastic are at risk of developing intestinal issues, liver metastasis, lipid metabolism, behavioral and energy disturbances (Jovanović, 2017). In certain cases, ingestion of microplastics may be fatal (digestion issues and/or locomotion issues) (Choi et al. 2018). Locomotion issues arise from low energy reserves and unable to effectively escape from a predator (Ding et al. 2017; Choi et al. 2018). As plastic waste fragments into microplastic. Many toxic compounds that were once used as additives are released. Toxic chemicals include polychlorinated biphenyls, and nonylphenols organic pesticides (bisphenol A) (Debroas et al. 2017).

Generally, the toxic chemical is not covalently bonded to the plastic polymer and can be easily separated as microplastics are formed. As a result, toxic chemicals accumulate in the local 
environment which can affect the normal functioning of the marine organism (Cai et al. 2018). It has been reported that $60 \%$ to $80 \%$ of floating litter in the oceans is made up of microplastics. Marine microbes are also affected by floating microplastics. Floating microplastics layers offer microbes an alternative substrate that can be used for microbial colonization and transportation, thus affecting the natural ecosystem of the ocean (Debroas et al. 2017). Due to the small size of microplastics, it has the ability to easily be transported to other water sources (seas, lakes, rivers, etc), by ocean currents, wind, tides etc. (Cai et al. 2018).

Freshwater sources can achieve up to $4 \mu \mathrm{g} / \mathrm{L}$ (Chen et al. 2017). The microplastic ingested by marine organisms/ animals are affected by the accumulation and release of toxic chemicals which also affects the quality of the surrounding environment (Hoffman et al. 2017). As the smaller ill organism/ animal are preyed upon, the larger animal/human ingested the toxins absorbed. As a result, moving up the food chain, have the potential to affect the human quality of life (Hoffman et al. 2017). Plasticizers additives are required to make consumer products more flexible and durable (Giovanoulis et al. 2018). Examples of plasticizers include phthalate esters, Bisphenol A (BPA), organophosphate esters (OPEs) (Wan et al. 2016; Chen et al. 2017; Giovanoulis et al. 2018).

Phthalates esters are used to improve flexibility, extensibility, and ease of processing (Chen et al. 2013). Phthalates can be categorized into two categories based on their molecular weight (Machtinger et al. 2018). The first category is referred to as low molecular weight phthalates that are used in personal care products (cosmetics, deodorant, shampoos, nail polish, etc.). Examples of low molecular weight phthalates include diethyl phthalate (DEP) \& di-isobutyl phthalate (DiBP). The second category is referred to as high molecular weight phthalates, which are used for adhesives, wallpaper, polyvinyl chloride, etc. Common examples of high 
molecular weight phthalates include di(2-ethylhexyl) phthalate (DEHP) \& di(isononyl) phthalate (DiNP) (Machtinger et al. 2018). Phthalates are not covalently bonded to the plastic product, therefore can leach out into the environment leading to human exposure and adverse events (Giovanoulis et al. 2018; Machtinger et al. 2018). Phthalates can contaminant the environment through direct or indirect pathways during different stages, during product use and end of life stages (disposal) (Wang et al. 2018).

Humans are continuously being exposed to phthalates by either digestion or inhalation. It has been reported that human's daily exposure to DEHP is $\simeq 2 \mathrm{mg} /$ day (Cho et al. 2015). Phthalates, in particular DEHP are known to be endocrine disrupting chemicals. Endocrine disrupting chemicals can lead to the development of endometriosis in humans (Cho et al. 2015). Generally, DEHP can be chemically broken down in the gut via hydrolysis into a metabolite known as mono-(2-ethylhexyl) phthalate. However, in females, DEHP can have an additive effect leading to infertility and other reproductive issues (Cho et al. 2015). Phthalates have also been associated to trigger oxidative stress in other human cells such as umbilical cells and placental cells. Oxidative stress has also been linked to cellular damage in lipids, proteins \& DNA and other anti-thyroid activities (Cho et al. 2015; Machtinger et al. 2018).

Bisphenol A (BPA) containing products are found everywhere since they are used to generate many different household items including drink bottles, paints, toys, food containers, etc. (Huang et al. 2017; Lin et al. 2017; Desai et al. 2018). BPA global consumption was estimated to be over 5.5 million tons in 2011 (Huang et al. 2017). BPA can leach out from food and drink containers and migrate into stored content (Jalal et al. 2018). Different factors such as heat and $\mathrm{pH}$ (acidic or basic) influence leaching profile from BPA containers (Jalal et al. 2018). A study conducted by Howe et al. (1998) investigated the potential exposure of BPA from 
coated cans. Howe et al. (1998) found that $6.6 \mu \mathrm{g} /$ person per day can be transferred from can to people, after ingestion the BPA passes into the bloodstream (Howe et al. 1998; Jalal et al. 2018). Interestingly, in 2016, dog and cat pet food will generate \$ 62.75 million (US) in sales (Koestel et al. 2017). As in humans, the increasing amount of canned food diet as an effect on a pet's health (Koestel et al. 2017).

As BPA reaches the gastrointestinal system, it is metabolized by the liver \& gut converting it into BPA-glucuronide (Huang et al. 2017). The half-life of BPA is $6 \mathrm{hrs,}$ as it accumulated over time, it poses a risk to develop adverse health events in the body (Huang et al. 2017). BPA like phthalate is an endocrine-disrupting chemical and is linked to many child and adult adverse health events (Cho et al. 2015; Desai et al. 2018). Due to the endocrine-disrupting chemical ability to bind to stimulate endogenous hormone receptors, past literature has established BPA association to reproductive, neurogenesis, neurological effects (Koestel et al. 2017; Desai et al. 2018). Interestingly, in 2016, dog and cat pet food will generate \$ 62.75 million (US) in sales (Koestel et al. 2017). As in humans, the increasing amount of canned food diet as an effect on a pet's health (Koestel et al. 2017). A study conducted by Kang et al. (2002) investigated the amount of BPA in pet canned food. Kang et al. (2002) found that in 15 different cat food brands, BPA range from 13 to $136 \mathrm{ng} / \mathrm{g}$. Kang et al. (2002) also observed 11 to $206 \mathrm{ng}$ /g in 11 different brands of dog food (Kang et al. 2002). In 2017, Koestel et al. (2017) determined the effects from a two-week canned food diet on dogs and found BPA levels were closely related to bicarbonate levels in the blood. As BPA increased the bicarbonate levels also increased. This relationship illustrated the potential higher risk of dogs developing renal and gastrointestinal disorders (Koestel et al. 2017). 
Global accumulation of plastic waste is a growing problem (Changwichan et al. 2018). To address this growing threat to the environment along with the reduction of petroleum resources, researchers are focused on developing/improving plastic recyclability (Avery-Gomm et al. 2018; Choi et al. 2018; Landon-Lane, 2018). One area of emphasis is to produce biodegradable plastic through renewable resources (Landon-Lane, 2018). Biodegradable plastics or bioplastics are referred to a category of plastics that are made from renewable biomass feedstock (plant-based) and other organic compounds that have the ability to degrade in the environment into smaller \&safer particles (Changwichan et al. 2018; Landon-Lane, 2018).

Bioplastics can be categorized into 4 different categories.

- Group 1: Bioplastic polymer derived directly from biomass such as starch \& cellulose (Garcia-Garcia et al. 2016).

- Group 2: Bioplastic polymer derived from monomers retrieved from renewable biomass through a chemical reaction (Garcia-Garcia et al. 2016).

- Group 3: Bioplastics polymers derived from non - renewable resources. An example includes fossil fuel (Garcia-Garcia et al. 2016).

- Group 4: Bioplastic derived from bacterial fermentation (Garcia-Garcia et al. 2016).

Bioplastics such as polyhydroxyalkanoates (PHA) can be produced through a microbial fermentation process (Group 4) and under certain processing conditions can produce similar characteristic similar to petroleum-based plastics (Changwichan et al. 2018). As bacteria are exposed to undesirable growth conditions, they are exposed to an oversupply of carbon with a limitation of one essential nutrient such as phosphorous or nitrogen (Cesario et al. 2014). As a 
result, during the fermentation process bacteria accumulate in the form of intracellular granules in the cytoplasm that serves as an energy source (Azizi et al. 2017). Past literature has established PHA benefits including being biocompatible and exhibiting thermoplastic characteristics (Zhila et al. 2018). Most importantly, PHA exhibits physical properties comparable to petroleum-based polymers (Yang et al. 2011). Table 1 compares PHB versus fossil-fuel produced plastic characteristics

Table 1.1 Compares PHA polymer characteristics with fossil-fuelled based plastics.

\begin{tabular}{|l|l|l|}
\hline Properties & PHB & $\begin{array}{l}\text { Fossil-Fuelled based plastics- } \\
\text { Polypropylene }\end{array}$ \\
\hline Crystallinity (\%) & 60 & 70 \\
\hline Tensile Strength (MPa) & 40 & 34.5 \\
\hline Melting Point $\left({ }^{\circ} \mathrm{C}\right)$ & 180 & 176 \\
\hline $\begin{array}{l}\text { Glass Transitional } \\
\text { Temperature }\end{array}$ & 4 & -10 \\
\hline Density (g/cm $\left.{ }^{3}\right)$ & 1.25 & 0.91 \\
\hline UV Light Resistance & Good & Poor \\
\hline Biodegradability & Good & Poor \\
\hline
\end{tabular}

Table 1.1 based on average values. Adapted from Akaraonye et al. 2010

Polyhydroxybutyrate (PHB) is a type of PHA (Azizi et al. 2017). Typically, PHB exhibit biocompatible, thermoplastic, nontoxic properties that can be used in the field of medicine (ex. controlled drug release applications) (Henrich et al. 2012; Huschner et al. 2015; Azizi et al. 2017). Figure 1 illustrates the chemical formula of PHB. 


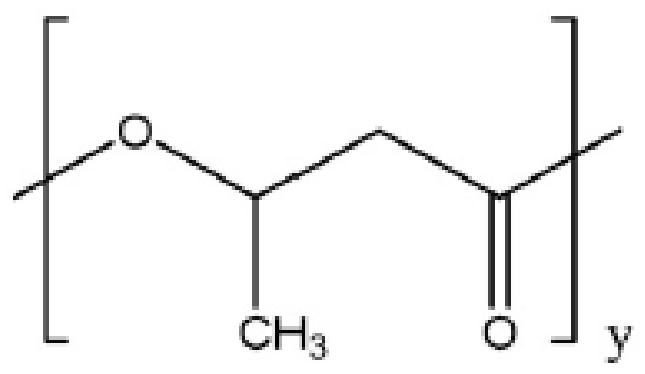

Figure 1.1 Illustrates the chemical formula for PHB. Adapted from Goonoo et al. 2017 


\section{Chapter 2 \\ Literature Review}

\subsection{PHB}

PHB can be made by either gram-negative or gram-positive bacteria under certain conditions (Yang et al. 2011). Ralstonia eutropha is one the most recognized bacteria among PHA-generating microorganism to effective accumulate large amounts of PHB. (Taguchi et al. 2003; Huschner et al. 2015). Ralstonia eutropha is also known as Cupriavidus necator is a gramnegative bacterium belonging to the of $\beta$ - proteobacteria (Lee et al. 2016). It has the ability to consume renewable carbon sources to synthesize PHB (Taguchi et al. 2003). Environmental parameters such as temperature, $\mathrm{pH}$, dissolved oxygen and other environmental conditions (carbon to nitrogen ratios $(\mathrm{C}: \mathrm{N})$ ) all influence $\mathrm{PHB}$ production via Ralstonia eutropha (Huschner et al. 2015; Kosseva, et al. 2018). The ideal temperature for Ralstonia eutropha-PHA production requires a temperature between $25{ }^{\circ} \mathrm{C}$ to $40{ }^{\circ} \mathrm{C}$, $\mathrm{pH}$ range between 5.5 to 7.9 (Huschner et al. 2015). Typical conditions of nutrient stress require an abundant source of carbon with a small (limited) amount of nitrogen, (Yang et al. 2011).

Two conditions to consider:

- Low $\mathrm{C}$ : $\mathrm{N}$ ratio: In this condition, more carbon is used to produce energy compounds, meaning less carbon for PHB production. The nitrogen is used for cell growth (Chakraborty et al. 2009). 
- High C: $\mathrm{N}$ ratio (ideal): In this condition, more carbon is available meaning more PHB production, while limited nitrogen cannot be used for cell growth (Chakraborty et al. 2009).

When bacteria are subjected to unbalanced growth conditions, they have the ability to accumulate PHA and other intracellular compounds (Noda et al. 2005; Burniol-Figols et al. 2018). The PHA acts as an energy storage mechanism (Noda et al. 2005). PHB which is a short chain length PHA is stored in the cytoplasm as an insoluble droplet (Lin et al. 2017). Once the energy storages are exhausted, microorganism uses the excess PHB for growth (Lin et al. 2017).

\subsection{Biorefinery}

Biorefinery is defined as "the sustainable processing of biomass into a spectrum of marketable products (food, feed, materials, and chemicals) and energy (fuel, power, and heat)" (Huijgen et al. 2012; IEA, 2014). An example is biofuels in particular bio-ethanols. Bio-ethanol is widely used in the United States \& Brazil as a good alternative for fossil fuels used for transportation (Pakarinen et al. 2012; Kuglarz et al. 2016; Lee et al. 2016). Another important feature of biofuel is the ability to be incorporated into existing fuel systems without difficult (Kuglarz et al. 2016).

Initially, bio-ethanol were produced using starched-based plants such as sugar cane. However, difficulties arise as the crop itself is not sustainable and/or crop cultivation is not possible in different parts of the world (Kuglarz et al. 2016). Next generation bio-ethanol shift the use of starch-based material to lignocellulosic-based that was attained from dedicated biomass or other forms of agriculture residues (Kuglarz et al. 2016). The goal of second- 
generation bio-ethanol is to use lignocellulosic material that has the ability to reduce carbon footprint in the atmosphere (Park et al. 2010; Pakarinen et al. 2012).

\subsection{Lignocellulosic Biomass}

Lignocellulosic-based material such as wheat straw and rice straw \& softwood are highly available inexpensive sources of carbohydrates. They are considered renewable and do not compete with global food production (Park et al. 2010; Cesario et al. 2014). Lignocellulosic is a reliable resource for biorefinery (Huijgen et al. 2012). The three main components of lignocellulose are cellulose $(\beta$-1,4-linked glucose polymer) hemicellulose (polymer containing hexose \& pentose) and lignin (phenol cross-linked polymer) (Galletti et al. 1991; Kupski et al. 2018). These three components make up the cell wall which acts as a physical barrier aimed to protect the inner tissues (Kupski et al. 2018). The cell wall physical barrier acts to support plant structural, impermeability and protector other forms of attack (microbial attack \& oxidative stress) (Cesario et al. 2014). Efficient disassembly into individual components is a prerequisite for an economically feasible lignocellulosic biorefinery (Huijgen et al. 2012).

Despite the individual components chemical structure, cellulose and hemicellulose are securely held by lignin in the cell wall (Jeun et al. 2015). The use of these two sugars is regulated by the structural resistance of the cell wall. This structural resistance is known as biomass recalcitrance (Jeun et al. 2015). Parameters affecting recalcitrance include biomass structural heterogeneity, amount of lignin and cellulose crystallinity (Wang et al. 2017). Once liberated, cellulose and hemicellulose demonstrate a good source of carbon to be used in further biological processes (Cesario et al. 2014). 


\subsection{Other Biomass Considered}

Sugars are an important source in human diet. Researchers aim to use non-food renewable resources for PHB production to prevent competition with food resources (Davis et al. 2013). Sources such as crude glycerol have been tested for PHA production (Burniol-Figols et al. 2018) Glycerol is an attractive biomass due to its high availability and low cost. In fact, glycerol is the by-product of biodiesel (Fukhi et al. 2014). However, there are three major challenges associated with glycerol as a resource (Burniol-Figols et al. 2018).

1. After the biodiesel production, glycerol along with other impurities are produced (Burniol-Figols et al. 2018). These impurities cannot be used in pharmaceutical industries. Further refinement is needed (Mozumder et al. 2014).

2. The molar mass of polymer produced at the end of production, affecting the quality of the polymer (Mozumder et al. 2014; Burniol-Figols et al. 2018)

3. The actual product produced only contains hydrobutrate which have to produce undesirable thermal characteristics when compared to PHB. Further processing is required (Burniol-Figols et al. 2018).

Another example is grass. Globally there are over 2.3 billion hectares of the total grass agriculture area available (Davis et al. 2013). In Europe alone, grass makes up approximately 240 million hectares of available grassland. The grass is an attractive biomass since it does not require fertilizer (cost) \& plowing of soil (labor) (Davis et al. 2013). Also by 2030, Europe would gain access to 19 million hectares of grass that would not disrupt Europe's food/agriculture sector (Davis et al. 2013). Grass is made up of two components, with one component which makes up of cellulose, hemicellulose, and lignin. Depending on the species, 
generally grass is made up of $25-40 \%$ cellulose, $15-50 \%$ hemicellulose and $10-30 \%$ lignin (Davis et al.2013; Cerrone et al. 2015). However due to its high lignin content, impedes its ability to be a bioaviable source, making grass less favorable to use (Davis et al. 2013).

Table 2.1 Summarizes the cellulose, hemicellulose and lignin content within different biomass

\begin{tabular}{|l|l|l|l|l|}
\hline Biomass & Cellulose & Hemicellulose & Lignin & Reference \\
\hline Wheat Straw & 30 & $(\%)$ & 20 & Dahman et al. 2014 \\
\hline Rice Straw & 31 & 50 & 13 & Chen et al. 2011 \\
\hline Rice Husk & 31 & 24 & 14 & Reddy et al. 2005 \\
\hline Barley Straw & 38 & 30 & 16 & Reddy et al. 2005 \\
\hline Sugar Cane & 43 & 31 & 11 & Martin et al. 2007 \\
\hline Banana & 63 & 7 & 7 & Reddy et al. 2005 \\
\hline Pineapple & 76 & 18 & 9 & Reddy et al. 2005 \\
\hline Grass & 33 & 33 & 20 & Reddy et al. 2005 \\
\hline Hemp & 55 & 16 & 4 & Garcia et al. 1998 \\
\hline
\end{tabular}

Note: Average content is listed from Reddy et al. 2005. Different species of the same biomass experience different climate and environmental stress (Cerrone et al. 2015). Table adapted from Reddy et al. 2005 
Table 2.2 List of agriculture waste in relation to the production of cell dry weight $(C D W)$ and PHA produced

\begin{tabular}{|c|c|c|c|c|c|}
\hline Source & Microorganism & $\begin{array}{l}\text { CDW } \\
\text { (grams/liter) }\end{array}$ & PHA Type & $\begin{array}{l}\text { PHA } \\
\text { produced } \\
(w / w)\end{array}$ & Reference \\
\hline Pea shells & $\begin{array}{l}\text { Bacillus } \\
\text { sphaericus }\end{array}$ & 2.50 & PHB & 1.60 & $\begin{array}{l}\text { Kumar et al } \\
2016\end{array}$ \\
\hline $\begin{array}{l}\text { Low-quality } \\
\text { waste animal } \\
\text { fats } \\
\text { (swine/cattle) }\end{array}$ & $\begin{array}{l}\text { Ralstonia } \\
\text { eutropha }\end{array}$ & 4.50 & PHB & - & $\begin{array}{l}\text { Riedel et al. } \\
2015\end{array}$ \\
\hline Pineapple & $\begin{array}{l}\text { Bacillus } \\
\text { sphaericus }\end{array}$ & 4.20 & - & 0.06 & $\begin{array}{l}\text { Suwannasing et } \\
\text { al. } 2015\end{array}$ \\
\hline Glycerol & $\begin{array}{l}\text { Ralstonia } \\
\text { eutropha }\end{array}$ & 1.81 & $\mathrm{P}(3 \mathrm{HB})$ & 1.08 & $\begin{array}{l}\text { Fukui et al. } \\
2014\end{array}$ \\
\hline Soybean Oil & $\begin{array}{l}\text { Ralstonia } \\
\text { eutropha }\end{array}$ & 6.80 & $\begin{array}{l}\text { P(3HBco- } \\
3 \mathrm{HHx})]\end{array}$ & 6.0 & $\begin{array}{l}\text { Insomphun et } \\
\text { al. } 2014\end{array}$ \\
\hline Rice & Bacillus firmus & 1.68 & PHB & - & $\begin{array}{l}\text { Sindhu et al. } \\
2013\end{array}$ \\
\hline Rice Husk & $\begin{array}{l}\text { Bacillus } \\
\text { mycoides }\end{array}$ & 0.47 & $\begin{array}{l}\mathrm{P}(3 \mathrm{HBco}- \\
3 \mathrm{HV})\end{array}$ & 0.07 & $\begin{array}{l}\text { Narayanan et } \\
\text { al. } 2014\end{array}$ \\
\hline Wheat Straw & $\begin{array}{l}\text { Ralstonia } \\
\text { eutropha }\end{array}$ & 15.3 & PHB & - & $\begin{array}{l}\text { Dahman et al. } \\
2014\end{array}$ \\
\hline \begin{tabular}{|l} 
Sunflower \\
Husk
\end{tabular} & $\begin{array}{l}\text { Ralstonia } \\
\text { eutropha }\end{array}$ & 8.82 & PHB & 7.69 & $\begin{array}{l}\text { Saratale, et al. } \\
2015\end{array}$ \\
\hline $\begin{array}{l}\text { Rice Paddy } \\
\text { straw }\end{array}$ & $\begin{array}{l}\text { Ralstonia } \\
\text { eutropha }\end{array}$ & 10.87 & PHB & 9.88 & $\begin{array}{l}\text { Saratale, et al. } \\
2015\end{array}$ \\
\hline $\begin{array}{l}\text { Orange Juice } \\
\text { Waste }\end{array}$ & $\begin{array}{l}\text { Ralstonia } \\
\text { eutropha }\end{array}$ & 9.58 & PHB & 7.31 & $\begin{array}{l}\text { Lagunes et al. } \\
2016\end{array}$ \\
\hline $\begin{array}{l}\text { Sugar Cane } \\
\text { Waste }\end{array}$ & $\begin{array}{l}\text { Bacillus } \\
\text { sphaericus }\end{array}$ & 9.00 & PHB & 5.00 & $\begin{array}{l}\text { Getachew et al. } \\
2016\end{array}$ \\
\hline Banana Waste & $\begin{array}{l}\text { Bacillus } \\
\text { sphaericus }\end{array}$ & 7.80 & PHB & 2.10 & $\begin{array}{l}\text { Getachew et al. } \\
2016\end{array}$ \\
\hline Corn Cob & $\begin{array}{l}\text { Bacillus } \\
\text { sphaericus }\end{array}$ & 9.30 & PHB & 4.80 & $\begin{array}{l}\text { Getachew et al. } \\
2016\end{array}$ \\
\hline
\end{tabular}

\subsection{Pre-treatment}

Production of PHB bioplastic requires three main stages. The first is pre-treatment followed by enzyme hydrolysis and finally fermentation (Zhu et al. 2015). Most agriculture waste considered is made up of a high amount of lignin which affects the performance of enzyme hydrolysis. In order to achieve maximum potential from enzyme hydrolysis, the agriculture 
waste must be first be pretreated (Zhu et al. 2015). In the cell wall, cellulose is a water-insoluble high crystalline structure made up of a long chain polymer of $\beta$-D-glucopyranose units. Hemicellulose is a heterogenous branched polymer made up of xylose \& hexose, galactose (Cesario et al. 2014; Gao et al. 2017). Lignin is an amorphous complex made up of a heteropolymer of phenylpropene units (Gao et al. 2017). Lignin acts as a barrier of cellulose that aims to improve the overall plant structure while restricting access to microbial attacks (enzymes) (Cesario et al. 2014; Zhou et al. 2018).

The biggest challenge in pre-treatment is the destruction of the cell wall lignin component (Bule et al. 2016). Pre-treatment accounts for up to $40 \%$ of the total processing cost (Zhang et al. 2009). The selection of a suitable pre-treatment process should consider the raw material, environmental impact, cost and further down streaming processes (Yuan et al. 2018). The ideal pre-treatment process should be able to provide material digestibility along with high yield of essential components (Yuan et al. 2018). Examples of pre-treatment processes investigated in the literature include, physical, chemical, thermal (Mohsenzudeh et al. 2012).

\subsubsection{Physical Pre-treatment}

Physical treatment is also known as mechanical pre-treatment and is used to reduce particle size and crystallinity while increasing the specific area and reduce the degree of polymerization (Gao et al. 2017). An example is ball milling. Ball milling is used to produce fine particles and has shown to increase enzyme digestibility (da Silva et al. 2010). A study conducted by da Silva et al. 2010 who investigated ball milling time (30 minutes to 120 minutes) effect on sugarcane bagasse and straw. da Silva et al. (2010) found that increasing the ball milling time for both bagasse and straw increased glucose and xylose yield. However, da Silva et al. (2010) found that depending on the component of sugarcane, different times were required to 
achieved similar glucose and xylose yield. Bagasse took 60 minutes to produce approximately $79 \%$ glucose and $72 \%$ xylose. While sugarcane straw took, 90 minutes (30 minutes longer) to produce approximately $78 \%$ glucose and $57 \%$ xylose (da Silva et al. 2010).

\subsubsection{Chemical Pre-treatment}

Chemical pre-treatments are considered to provide faster and efficient degradation of the cell wall (Mancini et al. 2018). Examples of the chemical pre-treatment include acidic and alkalization (Zhu et al. 2015; Yuan et al. 2018).

\subsubsection{Acidic Pre-treatment}

One widely used form of chemical pre-treatment is known as acidic pre-treatment (Zhu et al. 2015). Acidic pre-treatment works by hydrolyzing the hemicellulose into its individual monosaccharide composition. The lignin is condensed and precipitated at the same time (Jaisamut et al. 2016). Cellulose is released from lignin and enzymes used in enzyme hydrolysis now have more accessibility to the cellulose (Jaisamut et al. 2016). Utilization of a dilute acidic pre-treatment is cheap and can be easily applied (Zhu et al. 2015). An example is acidic pretreatment is diluted sulfuric acid (Dahman et al. 2014).

There are three major challenges associated with acidic pre-treatment. Firstly, not all lignin is precipitated, affecting the overall enzyme hydrolysis process (Zhu et al. 2015).

Secondly, toxic by-products that inhibit enzyme hydrolysis are produced during the decomposition of the cell wall (Jaisamut et al. 2016). Common by-products include phenolics (hydroxybenzoic acid), furfural, hydroxymethylfurfural (HMF) and other organic acids (Zhu et al. 2015; Zhou et al. 2018). HMF is generated from the dehydration of hexose such as glucose while furfural is produced by the dehydration of pentose such as xylose (Jaisamut et al. 2016). 
The final drawback is linked to the corrosion of equipment (Wu et al. 2018). These three challenges provide additional cost and neutralization processes (labor \& cost) that negatively impact the overall bioplastic production cost (Jaisamut et al. 2016).

\subsubsection{Alkalization Pre-treatment}

An alternative to acidic pre-treatment is the use of a different type of chemical pretreatment known as alkalization (Liu et al. 2015). For each glucose molecule within in the cellulose chain, there are three free hydroxyl groups, which makes the region polar (George et al. 2014). This makes bast fibers incompatible with nonpolar matrices. Furthermore, the hydroxy groups impact moisture absorption which can result in increased degradation rate (George et al. 2014). Alkalization can be used to prevent these issues (George et al. 2014). The crystalline regions are covered by the amorphous regions, making it difficult to interact with the cellulose. Alkalization can reduce the number of hydroxyl groups that exist in the amorphous region (Kabir et al. 2013). Examples of alkylation include sodium hydroxide and sodium carbonate (Yuan et al. 2018). Alkalization works by saponification and cleavage of the lignin bonds between cellulose and hemicellulose (degradation of ester and glyosidic linkages) (Brodeur et al. 2011; Mancini et al. 2018). This leads to cellulose swelling, surface area for enzyme interaction increases while decreasing crystallinity \& degree of polymerization (Liu et al. 2015).

Typically, alkalization pre-treatment conditions are less severe compared to acidic pretreatments. Alkaline pre-treatments can be executed under ambient environments but require a longer duration of time (Brodeur et al. 2011). For example, the study conducted by Sun et al. (1995) who studied alkaline pre-treatment effect of wheat straw cell wall found that pre-treating wheat straw with $1.5 \% \mathrm{NaOH}$ for 144 hours at $20^{\circ} \mathrm{C}$ can result in $60 \%$ removal of lignin (Sun et al. 1995; Brodeur et al. 2011). Alkalization involves soaking the biomass in the alkaline 
solution at a certain temperature for a duration of time (Brodeur et al. 2011). A Study conducted by Zhao et al. (2007) studied alkaline pre-treatment at low temperatures effect on spruce found that using $7 \% \mathrm{NaOH}$ pre-treatment for 24 hours at $23{ }^{\circ} \mathrm{C}$ can reduce lignin content by $18.7 \%$ (Zhao et al. 2007; Brodeur et al, 2011). After alkalization, a neutralization stage is required to remove lignin before enzyme hydrolysis can begin (Brodeur et al. 2011).

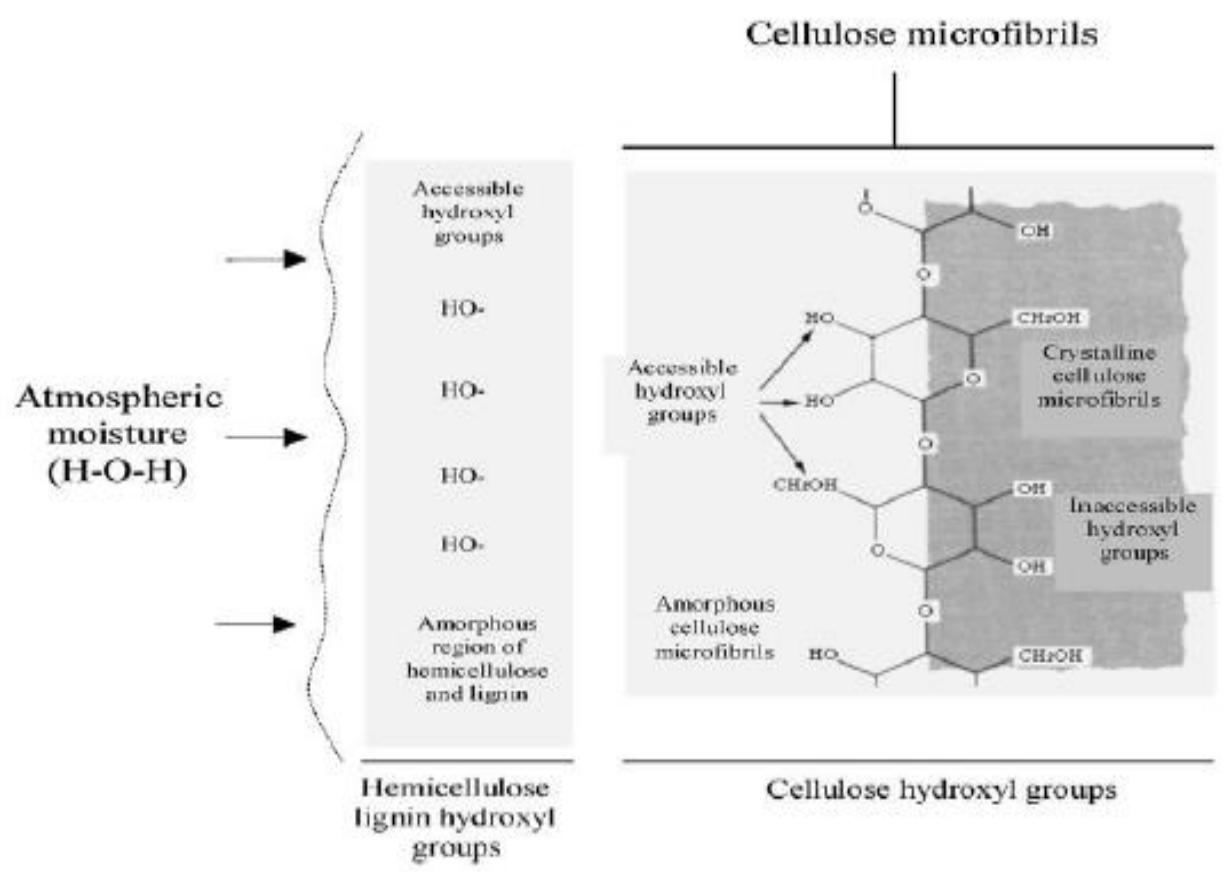

Figure 2.1Represents NaOH interaction with Hemp bast fibers. Adapted from Kabir et al. 2013

\subsubsection{Thermal Pre-treatment}

Chemical treatments are efficient but difficult to control (Rajput et al. 2018). In terms of acidic pre-treatment toxic by-products are produced (Rajput et al. 2018). Physical treatment, on the other hand, provides low investment and operational convenience (Rajput et al. 2018). Another physical treatment is known as a thermal treatment. Thermal treatment in literature is 
referred to as steam explosion or hydrothermal pre-treatment (Rajput et al. 2018). Thermal pretreatment is an environmentally friendly process, where the biomass is exposed to heat under a specific pressure over a specific period of time (Ferreira et al. 2013; Romani et al. 2016).

Generally, the temperature used is between 50 to $240{ }^{\circ} \mathrm{C}$ (Rajput et al. 2018). After the duration of time, the biomass is ejected into normal pressure, resulting in an explosion of macromolecules (Ferreira et al. 2013). Different factors affect the performance of thermal treatment including residence time, the temperature used and moisture content (Ferreira et al. 2013). These parameters affect the release of toxic by-products (Furfural, HMF) and the success of pretreatment (Ferreira et al. 2013). The advantage of thermal pre-treatment is the use without chemicals, less equipment erosion and limitation of concentration of toxic by-products (when parameters are controlled) (Wu et al. 2018). It should be noted that thermal pre-treatment alone cannot significantly affect the biomass cell wall (Wu et al. 2018). To further enhance the accessibility to cellulose a combination of physical/chemical pre-treatment process is required (Chen et al. 2018; Wu et al. 2018).

Table 2.3 Compares Physical, chemical, thermal pre-treatments

\begin{tabular}{|l|l|l|l|l|}
\hline $\begin{array}{l}\text { Pre-Treatment } \\
\text { Process }\end{array}$ & $\begin{array}{l}\text { Influential } \\
\text { Parameters }\end{array}$ & Advantages & Disadvantages & Reference \\
\hline \multicolumn{5}{|c|}{ Physical } \\
\hline Ball-Milling & $\begin{array}{l}\text {-Duration of } \\
\text { time } \\
\text {-Biomass used }\end{array}$ & $\begin{array}{l}\text {-Produce Fine } \\
\text { Particles } \\
\text {-Low } \\
\text { investment } \\
\text {-Ease of } \\
\text { operation } \\
\text {-No chemicals }\end{array}$ & $\begin{array}{l}\text {-Cleaning of } \\
\text { Equipment }\end{array}$ & $\begin{array}{l}\text { Da Silva } \text { et al. } \\
\text { 2010 } \\
\text { Gao } \text { et al. } 2017\end{array}$ \\
\hline Thermal & $\begin{array}{l}\text {-Residence } \\
\text { time } \\
\text {-Temperature } \\
\text { used }\end{array}$ & $\begin{array}{l}\text { - } \\
\text { Environmentally } \\
\text { friendly } \\
\text {-No Chemicals }\end{array}$ & -Energy \\
Requirements & $\begin{array}{l}\text { Rajput } \text { et al. } 2018 \\
\text { Ferreira } \text { et al. } 2013 \\
\text { Wu } \text { et al. } 2018\end{array}$ \\
\hline
\end{tabular}




\begin{tabular}{|c|c|c|c|c|}
\hline & $\begin{array}{l}\text {-Moisture } \\
\text { Content }\end{array}$ & $\begin{array}{l}\text {-Less } \\
\text { Equipment } \\
\text { Erosion }\end{array}$ & & \\
\hline \multicolumn{5}{|c|}{ Chemical } \\
\hline Acidic & $\begin{array}{l}\text {-Concentration } \\
\text { used }\end{array}$ & $\begin{array}{l}\text {-Inexpensive } \\
\text {-Produce High } \\
\text { Sugar yield }\end{array}$ & $\begin{array}{l}\text {-Toxic by- } \\
\text { products } \\
\text { (HMF, } \\
\text { furfural) } \\
\text {-Erosion of } \\
\text { equipment }\end{array}$ & $\begin{array}{l}\text { Zhu et al. } 2015 \\
\text { Zhou et al. } 2010 \\
\text { Dahman et al. } 2014\end{array}$ \\
\hline Alkalization & & $\begin{array}{l}\text {-Cellulose } \\
\text { swelling } \\
\text {-Increase } \\
\text { surface area } \\
\text {-Decrease } \\
\text { crystallinity } \\
\text {-Decrease of } \\
\text { polymerization }\end{array}$ & $\begin{array}{l}\text {-May affect } \\
\text { Cellulose and } \\
\text { Hemicellulose }\end{array}$ & $\begin{array}{l}\text { Liu et al. } 2015 \\
\text { Mancini et al. } 2018\end{array}$ \\
\hline
\end{tabular}

\subsubsection{Combinational Pre-treatment}

Thermal pre-treatment has been effective in the use of hardwood, softwood, sugar cane and wheat straw (Ballesteros et al. 2006). To further enhance the pre-treatment stage both acidic and alkali chemical pre-treatment are used to improve productivity (Ballesteros et al. 2006). Past literature establishes the use of physical/chemical combination used to increase the yield of sugars and while decreasing the temperature and time requirements (Ballesteros et al. 2006). Hence reduce energy requirements reducing pre-treatment production cost (Wu et al. 2018).

A study conducted by Ballesteros et al. (2006) illustrated the use of $0.9 \% \mathrm{H}_{2} \mathrm{SO}_{4}$ combining with a further 10 minutes of thermal pre-treatment to achieve optimal yield with wheat straw (Ballesteros et al. 2006). Wu et al. (2018) demonstrated improved enzyme hydrolysis through the use of thermal pre-treatment and post alkylation. In this study, autohydrolysis was performed at $140{ }^{\circ} \mathrm{C}$ for 40 minutes followed by 1-hour exposure to $6 \%$ 
sodium hydroxide (Wu et al. 2018). As a result, enzyme hydrolysis increased from $36 \%$ (controlled) to $83.7 \%$ (Wu et al. 2018). Thus, the combination of physical-chemical pretreatment is shown to decrease cost and minimize environmental pollution (Wu et al. 2018).

Table 2.4 Summarizes the different biomass and corresponding pre-treatment comparing cellulose, hemicellulose and lignin results

\begin{tabular}{|c|c|c|c|c|c|}
\hline \multirow[t]{2}{*}{ Biomass } & \multirow[t]{2}{*}{ Pre-treatment } & \multirow[b]{2}{*}{$\begin{array}{l}\text { Cellulose } \\
\text { / glucan }\end{array}$} & \multicolumn{2}{|l|}{ Composition } & \multirow[t]{2}{*}{ Reference } \\
\hline & & & $\begin{array}{l}\text { Hemicellulose/ } \\
\text { xylan }+ \\
\text { arabinan }\end{array}$ & Lignin & \\
\hline \multirow[t]{2}{*}{ Jute Fibers } & $\begin{array}{l}\text { Soaked } 5 \% \mathrm{NaOH} \\
\text { for } 4 \text { hours }\end{array}$ & 72.9 & 12.6 & 11.7 & \multirow[t]{2}{*}{$\begin{array}{l}\text { Liu et al. } \\
2009\end{array}$} \\
\hline & $\begin{array}{l}\text { Soaked } 5 \% \mathrm{NaOH} \\
\text { for } 4 \text { hours with } \\
\text { post } 1.5 \% \\
\text { KH-570 and for } \\
\text { another } 4 \text { hours }\end{array}$ & 77.6 & 11.4 & 9.6 & \\
\hline $\begin{array}{l}\text { Almond } \\
\text { Shell }\end{array}$ & $\begin{array}{l}\text { 2step: First step: } \\
\text { Sieving ( } 140 \text { um) \& } \\
\text { Drying at } 60^{\circ} \mathrm{C} \text { for } \\
24 \text { hours } \\
\text { Second } \mathrm{Step}: 5 \% \\
\mathrm{NaOH}\left(80^{\circ} \mathrm{C} \text { for } 2\right. \\
\text { hours) then } 10 \% \\
\mathrm{H}_{2} \mathrm{O}_{2}\left(80^{\circ} \mathrm{C} \text { for } 2\right. \\
\text { hours). Finally } \\
\text { drying at } 60^{\circ} \mathrm{C} \text { for } 2 \\
\text { hours. }\end{array}$ & 46.25 & 7.56 & 29.85 & \multirow[t]{2}{*}{$\begin{array}{l}\text { Sánchez- } \\
\text { Safont et al. } \\
2018\end{array}$} \\
\hline Rick Husk & $\begin{array}{l}\text { 2step: First step: } \\
\text { Ultracentrifugally } \\
\text { milling }(125 \text { um }) \& \\
\text { Drying at } 60^{\circ} \mathrm{C} \text { for } \\
24 \text { hours. } \\
\text { Second Step: } 5 \% \\
\mathrm{NaOH}\left(80^{\circ} \mathrm{C} \text { for } 2\right. \\
\text { hours }) \text { then } 10 \% \\
\mathrm{H}_{2} \mathrm{O}_{2}\left(80^{\circ} \mathrm{C} \text { for } 2\right. \\
\text { hours }) . \text { Finally } \\
\text { drying at } 60^{\circ} \mathrm{C} \text { for } 2 \\
\text { hours. }\end{array}$ & 31.13 & 18.6 & 28.25 & \\
\hline
\end{tabular}




\begin{tabular}{|c|c|c|c|c|c|}
\hline Seagrass & $\begin{array}{l}\text { 2step: First step: } \\
\text { Ultracentrifugally } \\
\text { milling }(125 \text { um }) \& \\
\text { Drying at } 60^{\circ} \mathrm{C} \text { for } \\
24 \text { hours. Then } 3 \% \\
\mathrm{CH}_{3} \mathrm{COOH} \\
\mathrm{Second} \mathrm{Step}: 5 \% \\
\mathrm{NaOH}\left(80^{\circ} \mathrm{C} \text { for } 2\right. \\
\text { hours) then } 10 \% \\
\mathrm{H}_{2} \mathrm{O}_{2}\left(80^{\circ} \mathrm{C} \text { for } 2\right. \\
\text { hours). Finally } \\
\text { drying at } 60^{\circ} \mathrm{C} \text { for } 2 \\
\text { hours }\end{array}$ & 38 & 21 & 27 & \\
\hline \multirow[t]{3}{*}{ Hemp } & Untreated & 46.1 & 10.1 & 18 & \multirow{3}{*}{$\begin{array}{l}\text { Pakarinen et } \\
\text { al. } 2012\end{array}$} \\
\hline & $\begin{array}{l}\text { Steam explosion } \\
\left(200^{\circ} \mathrm{C} \text { for } 5\right. \\
\text { minutes })\end{array}$ & 69.6 & 5.5 & 16 & \\
\hline & $1 \% \mathrm{NaOH}$ & 83.6 & 8.4 & 7.2 & \\
\hline \multirow[t]{3}{*}{$\begin{array}{l}\text { Wheat } \\
\text { Straw }\end{array}$} & $\begin{array}{l}0.35 \mathrm{M} \mathrm{NaOH} \text { for } 6 \\
\text { hours }\end{array}$ & 48.8 & 23.6 & 21.9 & \multirow[t]{2}{*}{$\begin{array}{l}\text { Yuan et al. } \\
2018\end{array}$} \\
\hline & $\begin{array}{l}0.35 \mathrm{M} \mathrm{NaOH} \text { for } 6 \\
\text { hours followed by } \\
0.35 \mathrm{Na}_{2} \mathrm{CO}_{3}\end{array}$ & 46.6 & 23.0 & 20.1 & \\
\hline & $\begin{array}{l}2 \% \mathrm{NaOH} \text { with } \\
\text { Autohydrolysis } \\
\left(140^{\circ} \mathrm{C}\right)\end{array}$ & 93.3 & 80.7 & 33.9 & $\begin{array}{l}\text { Wu et al. } \\
2018\end{array}$ \\
\hline
\end{tabular}

\subsubsection{Other Considerations}

A pre-treatment of lignocellulosic biomass issue is related to cost and ability to overcome biomass recalcitrance. While researchers still focus on improving the pre-treatment stage for lignocellulosic material (Kreuger et al. 2011). Other research is now shifting focus towards another economically feasible crop that can provide a higher yield while providing a low environmental impact (Kreuger et al. 2011). 


\subsection{Hemp}

An alternative to lignocellulosic biomass is hemp (Kreuger et al. 2011). Hemp is Cannabis that is mainly made up of cannabidiol (Schluttenhofer et al. 2017). In North America, hemp can only be considered as "hemp" when the concentration of THC (Tetrahydrocannabinol) is below 0.3\% (Schluttenhofer et al. 2017). Hemp can produce high biomass yield while having a low susceptibility to pest (Kreuger et al. 2011; Kuglarz et al. 2016). The plant itself can adapt and grow in different geographic climates as illustrated in Figure 1 (Salentijn et al. 2015). Canada, China, and North Korea are among the highest largest producers of hemp (Schluttenhofer et al. 2017). Canada had banned production of hemp from late 1930s to 1998. From 1998, the Canadian government has provided different grants to develop/ grow new hemp cultivators and improve hemp processing technologies. In 2012, to fuel the industry, Canada had certified hemp as a bio-based crop and food safety accreditation was provided (Salentijn $e t$ al. 2015). As demand for renewable sustainable products increased, hemp has the potential to be used for this growing market (Schluttenhofer et al. 2017). Recently hemp has integrated into the automotive, textile, paper, bio-fuel, construction, cosmetic \& personal care industries (Salentijn et al. 2015). Recently there has been an increased demand for hemp products from the United States, while many other countries around the world are now considering hemp as a highly sustainable crop. The global markets are expected to double between 2016 to 2020 (Schluttenhofer et al. 2017).

Hemp is made up a woody core and bast fibers (Schluttenhofer et al. 2017; Xie, 2017). In 1998, a study conducted by Garcia et al. (1998) investigated the individual components of hemp bast fibers and woody core. The study found that bast fibers provided a higher amount of cellulose, hemicellulose, pectin, and lignin compared to woody core (Garcia et al. 1998). In 
order to attain the maximum cellulose, hemicellulose content, the bast fibers must be separations from the woody core. The process of separations is known as retting. Retting is responsible for the improvement the quality of hemp for a future product for use (Schluttenhofer et al. 2017). Typically, hemp cell wall is made up of $55 \%$ cellulose, $16 \%$ hemicellulose and $4 \%$ lignin (Garcia et al. 1998). Hemp high cellulose content and low lignin composition have the potential to be used for different bioplastic applications (Kreuger et al. 2011).

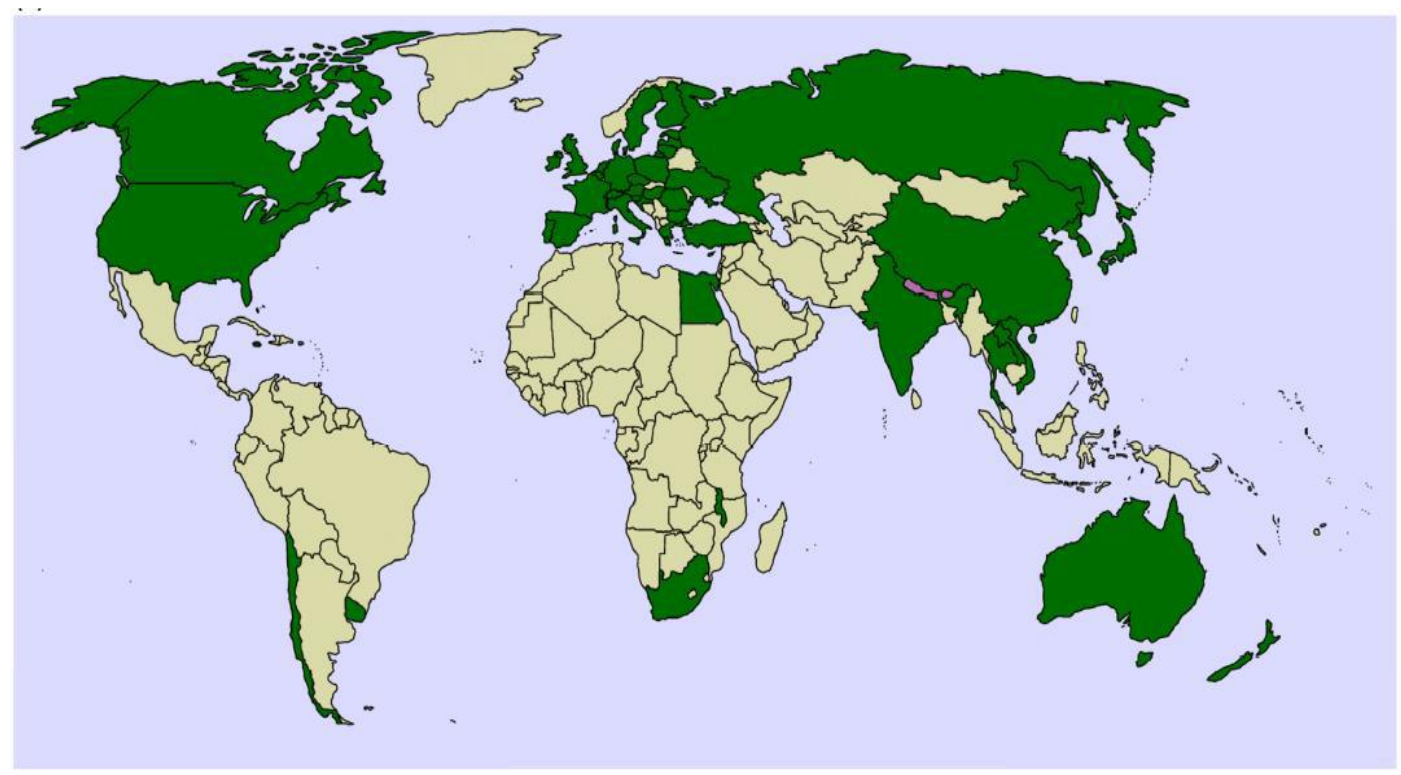

Figure 2.2 Illustrates countries that are currently producing hemp. Adapted from Schluttenhofer et al. 2017

\subsection{Extraction Method}

There are many different processes used to recover PHB from bacteria (Yang et al. 2011). Extraction processes include organic solvents, differential digestion, and detergent base (Yang et al. 2011). The extraction process influences the polymer quality (Macagnan et al. 
2017). Organic solvents such as chloroform and dichloromethane are generally used to extract

PHB. The disadvantage of the organic solvent is the use of large amounts required to

successfully extract PHB. This, in turn, can account for $50 \%$ or more of the total cost of polymer production (Yang et al. 2011). However, the use of an organic solvent is considered a simple recovery method with the ability to remove unwanted endotoxins that cause degradation to the polymer (Kunasundari et al. 2011).

Organic solvent extraction is made up of two stages.

- Stage 1: PHB release via cell membrane permeability changes (Kunasundari et al. 2011).

- Stage 2: PHB precipitation generated from non-organic solvents. Examples include methanol and ethanol (Kunasundari et al. 2011).

Table 2.5 Compares different PHB extraction methods

\begin{tabular}{|c|c|c|}
\hline Extraction Method & Beneficial Properties & Non-Beneficial Properties \\
\hline $\begin{array}{l}\text { Organic Solvent } \\
\text { Ex. Chloroform, } \\
\text { dichloromethane }\end{array}$ & $\begin{array}{l}\text {-Endotoxin Elimination } \\
\text {-Generates High molecular } \\
\text { Weight Product } \\
\text {-Generate High Purity } \\
\text {-Minor Polymer degradation }\end{array}$ & $\begin{array}{l}\text {-Not Eco-friendly } \\
\text { - A large amount of solvent } \\
\text { used } \\
\text {-Intensive Labour } \\
\text {-Time Consuming }\end{array}$ \\
\hline $\begin{array}{l}\text { Chemical Digestion Method } \\
\text { Ex. Sodium Hypochlorite }\end{array}$ & $\begin{array}{l}\text {-Reproducible molecular } \\
\text { weight recovered }\end{array}$ & -Low Purity \\
\hline $\begin{array}{l}\text { Supercritical Fluid } \\
\text { Ex. Ammonia, Methanol }\end{array}$ & $\begin{array}{l}\text {-Simple } \\
\text {-Cheap } \\
\text {-Eco-friendly }\end{array}$ & $\begin{array}{l}\text {-Hard to recover polar } \\
\text { compounds } \\
\text {-Clean up issues } \\
\text {-Compatibility issues with } \\
\text { natural compounds }\end{array}$ \\
\hline
\end{tabular}

Adapted from Kunasundari et al. 2011 


\subsection{Fermentation Process}

In order to move towards a large scale of production, bioreactors should be used (Kaur et al. 2015). There are different bioreactors available including batch, fed-batch, and continuous reactors. Bioreactors offer cost benefits such as

- Operating at required temperature to maximize production

- Reducing the potential of contamination to the product

Adapted from Kaur et al. 2015

Batch fermentations are considered the easiest and should be used as the initial assessment towards developing PHB (Kaur et al. 2015). Past literature focuses on different operating procedures, novel carbon sources conversion, along with the use of different bacteria (Kaur et al. 2015). It is described as a closed system, where at the start of the experiment, the substrate and other components are added, react within the reactor and once the reaction is completed, the product can be removed (Kaur et al. 2015). The disadvantage of this fermentation process is that it requires additional substrates or components that cannot be added during cultivation. The sample cannot be withdrawn during the reaction period, so no intermediate analysis can be conducted (Kaur et al. 2015).

Fed-batch fermentations avoid the issue of starvation of bacteria that usually occur in batch reactors at the end of the reaction. Fed-batch reactors also provide a solution to add addition substrates to the system during the cultivation period. This allows the substrate to be within their ideal fermentation substrate concentration. Other parameters that fed-batch fermentation reactors can control include the $\mathrm{pH}$, concentration of substrate and dissolved oxygen. Controlling these parameters allow an end result of high cell density and PHB production (Kaur et al. 2015). 
The highest fermentation performance process involves the use of continuous fermentation bioreactors. Advantages of continuous bioreactors include high dilution rates resulting in high concentrations that can provide highly stable production rates (Kaur et al. 2015). Disadvantages of continuous bio-reactors include the high risk of bacterial contamination, which can affect the time and cost associated with loss of production. However, it should be noted that an appropriate environmental procedure should be in place, along with more resistant bacteria can help lower the risk of contamination (Kaur et al. 2015).

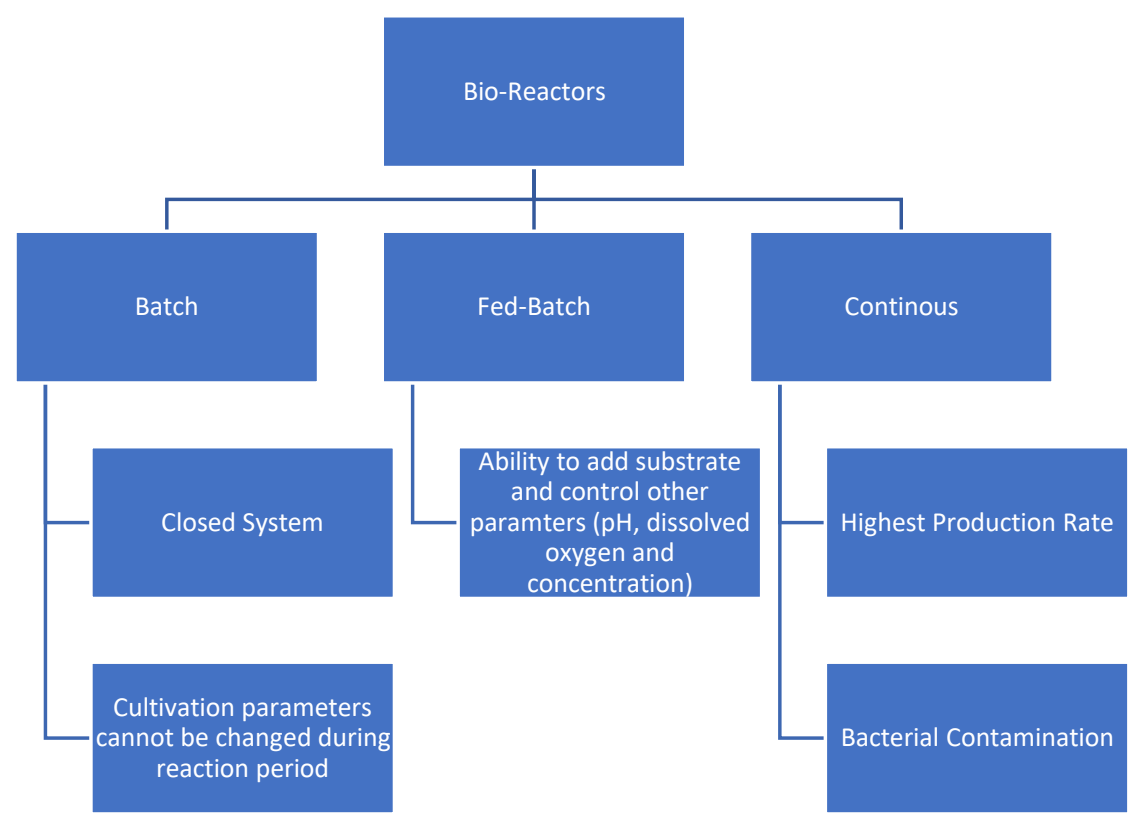

Figure 2.3 Summarizes bioreactors categories and features. Adapted from Kaur et al. 2015

\subsection{Processability}

The major challenge for industrial production of bioplastics is to acquire/achieve cost competitiveness against conventional fossil fuels produced plastics (Akiyaman et al. 2003). In 
order to achieve competitiveness, researchers and industrial partners must develop cost competitive methods to increase production (Akiyaman et al. 2003). One strategy to overcome PHB properties is to add a copolymer. The addition of copolymers has the ability to decrease the melting point and glass transition temperature while improving internal stability (Modi et al. 2011). An example is a study completed by Modi et al. (2011) where poly-(3-hydroxy valerate) was added to PHB which helped improve processing temperature by decreasing the melting point. This study demonstrated the potential of co-polymer addition to being used in processed into polymers similar to other petroleum-based products (Modi et al. 2011).

An alternative to co-polymer addition is the blending method. Generally, the blending method is easier and faster way to improve PHB properties and lower processing cost (Abdelwahab et al. 2012; Mousavioun et al. 2013). Most importantly the blending method is environmentally friendly, solvent-free and can be easily executed in different designed chemical reactions under different processing conditions. The results from these designs can then be easily manipulated to meet the final desired requirements (Pryzbysz et al. 2018). Blending starch with PHB has gained interested in producing low-cost bioplastic (Ma et al. 2014). Starch is a unique resource since it's renewable and can be derived from different biomass including potatoes, wheat and maize (Ma et al. 2014). Interestingly, starch is the ideal candidate to fossil-based polymers since it's cheaper to produce starch compared to other oil. However, starch has a high molecular weight and exhibits severe thermal degradation, limiting its processability on a large scale (Ma et al. 2014). An alternative to starch is the use of thermoplastic starch (TPS) which are made from gelatinized starch and additives that help improve starches processability (Ma et al. 2014). Studies such as the one conducted by Ma et al. (2014) who investigated starch effect illustrate the use of starch with PHB blends can improve toughness (Ma et al. 2014). 
Literature has also used PCL (Polycaprolactone) as a component in PHB blends. PCL is a hydrophobic aliphatic polyester. PCL is obtained from both non- renewable resources such as crude oil and renewable resources such as polysaccharides (Gutiérrez et al. 2017). PCL is a biodegradable thermoplastic that exhibits a low viscosity, low melting point $\left(\simeq 60^{\circ} \mathrm{C}\right)$, low glass transitional temperature $\left(\simeq-60^{\circ} \mathrm{C}\right)$, semi-crystalline structure (Gutiérrez et al. 2017). This allows PCL to be processed easily with typically manufacturing equipment. Other advantages of PCL include it being biocompatible, excellent stretch-ability and low water vapor permeability (Gutiérrez et al. 2017).

Currently, Polylactic acid (PLA) is the first choice for the commercial biodegradable polymer used to produce films in food packaging applications (Arrieta et al. 2015). PLA like PCL has a semi-crystalline structure, derived from lactic acid. Lactic acid can be found in different renewable resources such as corn, sugar beet and wheat (D'Amico et al. 2016). Lactic acid is also found in the human metabolic cycle, which indicates that lactic acid is non-toxic and biocompatible (Darie-Niţă et al. 2015). PLA is resistant to solvents and provides a good barrier to vapor and other gases (Darie-Niţă et al. 2015). Other advantages of PLA include its ability to be degraded and retuned backing into its original component (lactic acid) via ester hydrolysis. The lactic acid can then be recycled and be used for subsequent production of PLA (Darie-Niţă et al. 2015). For these reasons, The FDA (Food and Drug Administration) has approved it use (Darie-Niţă et al. 2015).

PHB and PLA share common properties. For example, PLA has a melting point of $\simeq 180$ ${ }^{\circ} \mathrm{C}$, and becoming brittle as a final product (D'Amico et al. 2016). PLA itself has a semicrystalline structure and a glass transitional temperature of $\simeq 80^{\circ} \mathrm{C}$. Due to these characteristics, PLA also exhibits poor toughness and difficulty being processed at higher stress levels (Darie- 
Niţă et al. 2015). Production cost of PLA can be high compared to petroleum-based plastics (Darie-Niţă et al. 2015). In order to overcome these problems, PHB blends provide a method to improve plastic and cost properties (D’Amico et al. 2016). Different blends provide different properties. For example, a study conducted by Zhang et al. (2011) who investigated the mechanical properties between different ratios of PLA-PHB blends found that PLA (75\%) / PHB (25\%) illustrated better tensile characteristics and mixing behavior compare to other blends studied (Zhang et al. 2011). Literature has also shown that PLA and PHB together appropriate mixing is dependent on the molecular weight of each component. For example, when PHB is mixed with a high molecular weight $(\mathrm{MW}>18,000)$ demonstrated a biphasic separation, while PHB mixed with a low molecular weight $(\mathrm{MW}<18,000)$ produces a well-balanced mixture (Abdelwahab et al. 2012). On the other hand, PLA can also be mixed with low molecular weight PHB (MW < 9400) and miscible with high molecular weight PHB (MW> 9400) (Abdelwahab et al. 2012). Factors affecting plasticizers performance include chemical structure of polymer and other processing parameters related to mixing (Garcia-Garcia et al. 2016). Other factors such as biocompatibility, compatibility with polymer, the amount of plasticizer used to achieve desired properties should all be considered (Darie-Niţă et al. 2015).

\subsection{Objectives}

Petroleum-based plastics are not biodegradable and accumulate over time, causing environmental pollution (Sun et al. 2018). The increasing concern over petroleum resources and environmental impact has led to extensive research focused on developing biodegradable plastics acquired from renewable resources (Scaffaro et al. 2018). Past literature has focused on lignocellulosic biomass to produce PHB, however there is limited information available 
regarding to the use of hemp (Dahman et al. 2014). The purpose of this study is to examine the ability to produce PHB using renewable and sustainable green feedstock of hemp. As shown in Table 2.1, hemp has a relatively high cellulose and the lowest lignin content compared to another biomass reviewed. Hemp was also chosen due its low cost and availability in Canada (Figure 2.2) (John et al. 2007; Schluttenhofer et al. 2017)

As a result, different pre-treatments and hydrolysis methods were studied to determine optimize simple sugars availability from hemp for separate hydrolysis and fermentation process to increase PHB production. Table 2.2 summarizes agriculture waste in relation to the production of cell dry weight and PHA produced. Examining Table 2.2 reveals that Ralstonia eutropha are able to produce higher cell dry weight and PHB compared to other bacterial species. In this study, Ralstonia eutropha will be used in an attempt to increase production.

In this study, a comparison between pre-treatment effectiveness was created between different combinations of physical, chemical and thermal pre-treatments and their effect on PHB production. Enzyme production effectiveness was also established by comparing enzyme type, dosage, and combination enzyme therapy to determine optimum parameters in regards to PHB production. Extraction comparison in relation to sonification and its effect on PHB production was also determined. Samples were collected with time to determine $\mathrm{pH}$ control effect on PHB production. 


\section{Chapter 3 \\ Experimental Methods and Procedures}

\subsection{Materials}

In this study, Ralstonia eutropha (ATC 17699) was purchased from the American

Culture Collection Center (Manassas, US). Hemp fibers obtained from a farm in Manitoba.

Chemicals were purchase from Sigma Aldrich, Baker \&Adamson, AnalaR analytical reagents.

All materials were used as received without further purification unless mentioned. Water HPLC

grade submicron filtered purchase from Fisher Chemicals. Tables 3.1 and 3.2 summarizes all

chemicals and enzymes that were used in the present study. Table A.1 in Appendix A

summarizes equipment serial per batch number with corresponding manufacture that were used in the study.

Table 3.1 Represents the chemicals used in this study

\begin{tabular}{|l|l|l|}
\hline \multicolumn{1}{|c|}{ Chemical } & Batch Number & Manufacture \\
\hline Ammonium Chloride & $129 \mathrm{~K} 01881$ & Sigma-Aldrich \\
\hline Ammonium iron (III) citrate & SLBR612V & Sigma-Aldrich \\
\hline Beef Extract & SLBQ3908V & Sigma-Aldrich \\
\hline Boric Acid & SLBQ5348V & Sigma-Aldrich \\
\hline Calcium Chloride & 070M0053V & Sigma-Aldrich \\
\hline Chloroform & SHBH8512 & Sigma-Aldrich \\
\hline Citrate Acid Monohydrate & $0901 \mathrm{M} 0157 \mathrm{~V}$ & Sigma-Aldrich \\
\hline $\begin{array}{l}\text { Copper Chloride, Reagent } \\
\text { grade, } 97 \%\end{array}$ & MKAA0267 & Sigma-Aldrich \\
\hline D-(+)-Glucose ACS reagent & SLPBP5997V & Sigma-Aldrich \\
\hline $\begin{array}{l}\text { D-(+)-Xylose, minimum } \\
\text { 99\% }\end{array}$ & 010 M0063 & Sigma-Aldrich \\
\hline Hemp & N/a & Farm in Manitoba \\
\hline Hydrochloric Acid & SZBE1710V & Sigma-Aldrich \\
\hline $\begin{array}{l}\text { Manganese (II) Sulfate } \\
\text { Monohydrate, Minimum } \\
99 \%\end{array}$ & $126 \mathrm{~K} 0111$ & Sigma-Aldrich \\
\hline $\begin{array}{l}\text { Magnesium Sulfate } \\
\text { anhydrous, reagent }\end{array}$ & 208094-5006 & Sigma-Aldrich \\
\hline
\end{tabular}




\begin{tabular}{|l|l|l|}
\hline $\begin{array}{l}\text { Nickel (II) Chloride } \\
\text { hexahydrate }\end{array}$ & SLBQ6963V & Sigma-Aldrich \\
\hline Potassium Citrate & 2106 & Baker \& Adamson \\
\hline $\begin{array}{l}\text { Potassium dihydrogen } \\
\text { orthophosphate }\end{array}$ & 7701361 & AnalaR analytical reagent \\
\hline Sodium Hydroxide & MKBR2876V & Sigma-Aldrich \\
\hline Sodium Molybdate Dihydrate & $1441416 \mathrm{~V}$ & Sigma-Aldrich \\
\hline $\begin{array}{l}\text { Sodium Phosphate Dibasic } \\
\text { ACS reagent }\end{array}$ & $096 \mathrm{~K} 0141$ & Sigma-Aldrich \\
\hline Tryptone & $059 \mathrm{k} 0108$ & Sigma-Aldrich \\
\hline Yeast Extract & SLBM5481V & Sigma-Aldrich \\
\hline $\begin{array}{l}\text { Water HPLC Grade } \\
\text { Submicron Filtered }\end{array}$ & 177528 & Fisher Chemical \\
\hline $\begin{array}{l}\text { Zinc Sulfate Heptahydrate, } \\
\text { 99\%, A.C.S. reagent }\end{array}$ & $07128 \mathrm{CJ}$ & Sigma-Aldrich \\
\hline
\end{tabular}

Table 3.2 Represents the enzymes used in this study

\begin{tabular}{|l|l|l|}
\hline Enzymes & Batch Number & Manufacture \\
\hline $\begin{array}{l}\text { Cellulase from Trichoderma } \\
\text { reesi ATCC 26921 }\end{array}$ & $129 \mathrm{~K} 1869$ & Sigma-Aldrich \\
\hline $\begin{array}{l}\text { Cellulase from Trichoderma } \\
\text { reesei }\end{array}$ & SLBS6244 & Sigma-Aldrich \\
\hline Novozyme 188 & $078 \mathrm{~K} 0709$ & Sigma-Aldrich \\
\hline Novozyme 188 & $079 \mathrm{~K} 1446$ & Sigma-Aldrich \\
\hline $\begin{array}{l}\text { Xylanase from Thermomyces } \\
\text { lanuginosus }\end{array}$ & $018 \mathrm{~K} 1473$ & Sigma-Aldrich \\
\hline
\end{tabular}

\subsection{Hemp Biomass Pre-treatment \& Enzyme Hydrolysis}

\subsubsection{Hemp Physical Pre-treatment}

In this study, hemp was the sole biomass used. The hemp fibers were obtained from a farm in Manitoba and stored at room temperature in airtight bags. The hemp fibers were then manually separated from leaves. After separation, hemp was subjected to particle size reduction 
using a lab scale blender (Davis et al. 2013). The grinded hemp was then stored in airtight bags at $27^{\circ} \mathrm{C}$.

\subsubsection{Hemp Alkalization and Thermal Pre-treatment}

Initially, 100 grams of grinded hemp weight using balance and transferred into Erlenmeyer Flasks. Alkali pretreated hemp was obtained by suspending 100 grams grinded hemp in 1-liter alkali solution $(\mathrm{NaOH})$ concentrations $(2,5,10 \%(\mathrm{w} / \mathrm{v}))$. To produce $2 \% \mathrm{NaOH}$, required 20 grams of $\mathrm{NaOH}$ and was placed within a $1000 \mathrm{ml}$ volumetric flask. Distill water was used to make up the volume to $1000 \mathrm{ml}$. For $5 \% \mathrm{NaOH}, 50$ grams $\mathrm{NaOH}$ in $1000 \mathrm{ml}$ distill water. For $10 \% \mathrm{NaOH}, 100$ grams $\mathrm{NaOH}$ in $1000 \mathrm{ml}$ distill water was used. The reaction is exothermic, once cooled, the diluted alkai solution was added to the grinded hemp.

The pretreated hemp was then placed into a preheated incubator shaker (Thermo Scientific MaxQ 4450) at $32^{\circ} \mathrm{C}$ for 60 minutes. The Erlenmeyer flasks were continuously stirred within the incubator shaker at a constant rate of $200 \mathrm{rpm}$. After 60 minutes the pretreated hemp was autoclaved at $121^{\circ} \mathrm{C}$ for another 60 minutes. After pre-treatment, the pretreated hemp mixture was filtered into the solid faction (including insoluble solids) and a liquid fraction using an $11 \mathrm{~cm}$ Buchner Funnel (0.5-micron filter paper was used). The solid fraction was washed with deionised water until pH 7 was achieved (Kulgarz et al. 2016). The solid hemp fraction was then placed in the oven at $80^{\circ} \mathrm{C}$ for 24 hours to remove moisture (Sluiter et al. 2016).

\subsubsection{Pre-treatment Quality Control}

Accurate characterization of hemp and process intermediates is necessary for economic evaluations and quality control. Pretreated slurries are heterogenous mixtures and can affect 
further intermediate steps and overall PHB production (Slutier et al. 2011). Pretreated slurries are made up of a solubilized and insoluble phase. The solubilize phase contains the sugars, while insolubilize phase contains lignin. The National Renewable Energy Laboratory (NREL) define the wash method for the solid fraction. This method involves exhaustive and sequential washing with distilled water to remove liquor from the solid phase (Sluiter et al. 2016). The solid fraction also called pre-treated slurries had to be washed with deionised water until $\mathrm{pH} 7$ was achieved. Washing is conducted under a Buchner funnel, it should be noted that disproportionate vacuum should not be used as water evaporation will affect composition of pretreated biomass (Sluiter et al.2011). Calculating the efficiency of the pre-treatment method is known as FIS (fraction insoluble solids) which indicates the amount of lignin removed (Slutier et al. 2011; Slutier et al. 2016). It uses the solid fraction recovered after drying in relation to total wet slurry. In this study, FIS provides a comparison of samples for consisted based used for quality control. Consistency is based on pre-treatment used (Slutier et al. 2016).

Fractional Insoluble Solid $(F I S)=\frac{\text { Solid Fraction }_{\text {Dry }}}{\text { Slurry }_{\text {Dry }}} * 100 \quad$ Equation 1

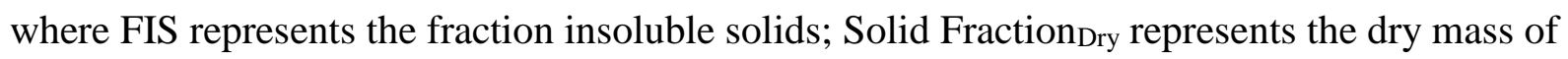
solids after pre-treatment, and Solid SlurryDry represents represent a wet slurry (Sluiter et al. 2016). 


\subsubsection{Enzyme Hydrolysis}

The recovered dried solid fraction was then subjected to enzyme hydrolysis. The solid fraction acts as a feed source and was placed into $500 \mathrm{ml}$ Erlenmeyer flasks. Different combination of enzymes (Cellulase from Trichoderma Reese, Novozyme 188 and Xylanase from Trichoderma longibrachiatum), were added at different concentrations (Refer to Table 6) along with $50 \mathrm{ml}-0.5 \mathrm{M}$ citrate buffer $(\mathrm{pH} \simeq 4.8)$. The citrate buffer was made from $8.236 \mathrm{~g}$ of potassium and $5.254 \mathrm{~g}$ of citric acid and mixed to $500 \mathrm{~mL}$ of de-ionized water. The hempenzyme mixture $\mathrm{pH}$ was adjusted to 7 . The Thermo Scientific MaxQ 4450 was then mixed the mixture for up to 72 hours at $48{ }^{\circ} \mathrm{C}$.

Table 3.3Represents the sample of Pre-treated hemp studied followed by Enzyme Addition Studied.

\begin{tabular}{|l|l|l|l|l|l|}
\hline \multirow{2}{*}{$\begin{array}{l}\text { Sample } \\
\text { Name }\end{array}$} & \multicolumn{3}{|l|}{ Pre-treatment Conditions } & \multicolumn{3}{l|}{ Enzyme Addition } \\
\cline { 2 - 6 } & $\begin{array}{l}\text { NaOH } \\
\text { concentration } \\
(\%)\end{array}$ & Autoclave used & $\begin{array}{l}\text { Cellulase } \\
(\mathrm{g} / \mathrm{l})\end{array}$ & $\begin{array}{l}\text { Novozyme } \\
(\mathrm{g} / \mathrm{L})\end{array}$ & $\begin{array}{l}\text { Xylanase } \\
(\mathrm{g} / \mathrm{L})\end{array}$ \\
\hline Batch 0 & 2 & Yes & - & - & - \\
\hline Batch 1 & 2 & No & 1.5 & - & - \\
\hline Batch 2 & 5 & No & 1.5 & - & - \\
\hline Batch 3 & 5 & No & 0.7 & - & - \\
\hline Batch 4 & 5 & No & 3.0 & - & - \\
\hline Batch 5 & 5 & No & 1.5 & 1.5 & - \\
\hline Batch 6 & 5 & No & 1.5 & 1.5 & 1.5 \\
\hline Batch 7 & 5 & Yes & 1.5 & 1.5 & 1.5 \\
\hline Batch 8 & 5 & Yes & 1.5 & 1.5 & 1.5 \\
\hline Batch 9 & 5 & No & - & 1.5 & 1.5 \\
\hline Batch 10 & 10 & No & 1.5 & - & - \\
\hline
\end{tabular}

*Samples were Autoclave $121^{\circ} \mathrm{C}$ for 60 minutes

* Batch 8 had an additional extraction step (Ultrasonication) 


\subsection{Bioplastic Production}

Bioplastic production experiments were conducted in $500 \mathrm{ml}$ Erlenmeyer flasks that were incubated with Thermo Scientific MaxQ 4450 at $28^{\circ} \mathrm{C}$ for five days. Fermentation was always conducted using Ralstonia eutropha, and hydrolysate solution of hemp that contains mixture of sugars (prepared according to section 3.2.2).

\subsubsection{Ralstonia eutropha activation}

Ralstonia eutropha was activated in a basal mixture. The basal mixture was made up of 1 gram beef extract, 1 gram tryptone and 0.2 gram yeast extract. These components were mixed with $100 \mathrm{ml}$ distilled water in 250 Erlenmeyer flasks. The mixture was mixed using the Thermo Scientific MaxQ 4450 incubator shakers for 30 minutes. After thorough mixing, the basal mixture was autoclaved at $121{ }^{\circ} \mathrm{C}$ for 20 minutes. The Labgard Class II, Type A2 Biological Cabinet was aseptically cleaned using ethanol (surfaces and equipment) and UV was used further sterilization for 10 minutes. After autoclave, the basal medium was allowed to be cooled to room temperature within an aseptically Biological Cabinet. After cooling, Ralstonia eutropha sample was then added to the basal medium under aseptic conditions. Adaptation of Ralstonia eutropha ATCC guidelines for activation led to Ralstonia eutropha being incubated for 120 hours at an initial $\mathrm{pH}$ of 7 at temperature of $30^{\circ} \mathrm{C}$ within Thermo Scientific MaxQ 4450 (150 $200 \mathrm{rpm})$ (Dahman et al. 2014). 


\subsubsection{Ralstonia eutropha addition}

After 48 hours of enzyme hydrolysis, hemp fibers were filtered using $11 \mathrm{~cm}$ Buchner funnel. The remaining hydrolysate was then adjusted to $\mathrm{pH}$ of 7 . The nitrogen-limited medium was produced adding to the hydrolysate a mixture of $3 \mathrm{~g} / \mathrm{L}$ of $\mathrm{Na}_{2} \mathrm{HPO}_{4}-12 \mathrm{H}_{2} \mathrm{O}, 0.5 \mathrm{~g} / \mathrm{L}$ of $\mathrm{KH}_{2} \mathrm{PO}_{4}, 1 \mathrm{~g} / \mathrm{L} \mathrm{NH}{ }_{4} \mathrm{Cl}, 0.1 \mathrm{~g} / \mathrm{L} \mathrm{MgSO}_{4}-7 \mathrm{H}_{2} \mathrm{O}, 1.2 \mathrm{mg} / \mathrm{L} \mathrm{Fe}$ (III) $\mathrm{NH}_{4}$ and $10 \mathrm{~mL}$ of trace elements. The trace elements composed of $10 \mathrm{mg} / \mathrm{L} \mathrm{ZnSO}_{4}-7 \mathrm{H}_{2} \mathrm{O}, 3 \mathrm{mg} / \mathrm{L} \mathrm{MnCl}_{2}-4 \mathrm{H}_{2} \mathrm{O}, 30$ $\mathrm{mg} / \mathrm{L} \mathrm{H}_{3} \mathrm{BO}_{3}, 20 \mathrm{mg} / \mathrm{L} \mathrm{CaCl}_{2}-6 \mathrm{H}_{2} \mathrm{O}, 1 \mathrm{mg} / \mathrm{L} \mathrm{CuCl}_{2}-6 \mathrm{H}_{2} \mathrm{O}, 2 \mathrm{mg} / \mathrm{L} \mathrm{NiCl}_{2}-6 \mathrm{H}_{2} \mathrm{O}$ and $3 \mathrm{mg} / \mathrm{L}$ $\mathrm{NaMoO}_{4}-2 \mathrm{H}_{2} \mathrm{O}$. After all, components were added, the $\mathrm{pH}$ was adjusted to 7 . Hydrolysate and the nitrogen limiting medium was then autoclaved (Dahman et al. 2014). The activated Ralstonia eutropha $(5 \% \mathrm{w} / \mathrm{v})$ was added to the hydrolysate and nitrogen limited nutrient medium at a temperature of $28{ }^{\circ} \mathrm{C}+/-2{ }^{\circ} \mathrm{C}$. The solution was sterilized and then placed in the Thermo Scientific MaxQ 4450 for a maximum of 5 days. After 5 days, PHB was produced within the flask.

\subsection{Extraction}

After fermentation, PHB extraction was required. Fermentation resultant broths contained PHB lyophilized cells. The broth was placed in VWR test tubes and centrifuged at $4000 \mathrm{~g}$ for 15 minutes using accuSpin 400 Centrifuge. After centrifuging the samples, solid formed at the bottom (contained PHB lyophilized cells). The liquid layer was discarded. The solid phase was then immersed in a chloroform. For each gram of PHB lyophilized cells, approximately $50 \mathrm{ml}$ of chloroform was added. The chloroform and PHB were mixed thoroughly using Analog Vortex Mixer VM-3000. Once completed, all test tubes mixtures were placed within the round bottom flask. The round bottom flask was then attached to a reflux condenser under a heated oil bath (80 
${ }^{\circ} \mathrm{C}$ ) for 4 hours (Dahman et al. 2014). The PHB was recovered from the precipitating solvent. The weight of PHB was then measured (Dahman et al. 2014).

\subsection{HPLC Analysis}

HPLC was used to investigate separate hydrolysis and fermentation process sugar content. Sampling was done within the aseptic cleaned biological cabinet. All surfaces and equipment used were aseptically sterilized using ethanol and further utilization of UV for 10 minutes. Samples diluted by a factor of 50, centrifuged at $4000 \mathrm{~g}$ for 15 minutes and filtered through $45 \mu \mathrm{m}$ filter. Samples were collected at the start of fermentation and then intervals of 24 hours until end of fermentation. Sterilized Eppendorf tubes were used to store $2 \mathrm{ml}$ samples for each interval. Samples were stored at $-80^{\circ} \mathrm{C}$ in Revco Elite Plus Freezer until quantified. Sugar was quantified using HPLC apparatus. The results obtained from analyzing three samples.

Sugar concentration was determined using HPLC apparatus; Agilent Technologies 1260 infinity series equipped with autosampler injector and a refractive index detector (serial \# DEAA302993). The Shodex SP0810 column was used to determine sugar concentrations. HPLC was operated using water HPLC grade microfiltered as the mobile phase. The mobile phase was used to increase the flow rate to $0.6 \mathrm{ml} /$ minute for 30 minutes. A constant flow rate was then achieved. Adjusting flow rate reduces noise generated and provides a constant pressure within HPLC apparatus. The maximum allowable pressure was 300 bar. The column temperature was maintained at $80-85^{\circ} \mathrm{C}$. Once all parameters were achieved and maintained, the autosampler took $50 \mu \mathrm{L}$ for each sample. Each sample was analyzed for 35 minutes. It should be noted that HPLC grade water from Fisher Scientific was purchase in an attempt to reduce noise generated from the analysis. Also using HPLC grade water improved methodology previously described by Syed et al. (2014). Data were processed using the Openlab software. HPLC testing vials were 
filled to headspace to reduce the loss of solvent in the vapor phase (Syed et al. 2014). The reliability of HPLC results was confirmed by running analysis (sugars standards \& samples) triplicate. Sugar concentrations were determined from calibration curves (Appendix A) from standard sugar solutions of known concentrations $(10-1000 \mu \mathrm{g} / \mu \mathrm{L})$

\subsection{Statistical Analysis}

In this study, separate hydrolysis and fermentation analysis were repeated three times. Results are calculated average values according to Equation 1. Table 6.4 to Table 6.10 in Appendix display the raw data for individual sugar concentrations, FIS results in sugar concentrations and corresponding average, standard deviations and relative standard deviations percentage. Standard deviations were calculated according to Equation 2 and represented as error bars in Chapter 4 \& 6 Figures. All results listed are displayed as average values (Equation 2) (Kulgarz et al. 2016).

$\mu=\frac{1}{n} * \sum_{i=1}^{n} x_{i} \quad$ Equation 2

where $\mu$ represents the arithmetic mean; $\mathrm{n}$ represent the total number of samples tested $(\mathrm{n}=3)$, and $x_{\mathrm{i}}$ represents the observed value for each sample.

$\sigma=\sqrt{\frac{1}{n} * \sum_{i=1}^{n}\left(x_{i}-\mu\right)^{2}} \quad$ Equation 3

Let $\sigma$ represent the standard deviation

$R S D=100 * \frac{\sigma}{\mu} \quad$ Equation 4

Let RSD represent the relative standard deviation in $(\%)$ 
Results for all replicates are listed in Table A.2 to A.8 in Appendix A. According to these results average standard deviation in Table A.2 range from 0.14 to 1.01 with an average standard deviation of 0.76 . The relative standard deviation error for Table A.2 in the range of 0.2 to $1.6 \%$. Table A.3 and A.4 represent the sugar available after enzyme hydrolysis. The standard deviation ranges from 0.01 to 0.47 with an average standard deviation of 0.22 . The relative standard deviation for A.3 \& A.4 is 0.08 to $30 \%$. Table A.5 \&A.6 represent sugar reading during fermentation. The standard deviation ranges from 0.07 to 0.31 with an average standard deviation of 0.22 . The relative standard deviation for A.5 \& A.6 is 0.5 to $10.8 \%$. Table A.7 shows the wet mass produced in the experiment. The standard deviation ranges from 0.12 to 2.68 with an average standard deviation of 1 . The relative standard deviation for Table A.7 ranges from 0.5 to $11.1 \%$. Table A. 8 \& A.9 represent Batch $7 \mathrm{pH}$ readings. The standard deviation ranges from 0.31 to 0.93 with an average standard deviation of 0.60 . The relative standard deviation for Table A.8 \&A.9 ranges from 4 to $19.4 \%$. According to Table A. 2 to A.8 the average standard deviation of the whole study is 0.51 . 


\section{Chapter 4 \\ Results \& Discussion}

\subsection{Pre-treatment Effectiveness}

In this study, hemp was exposed to several different combinations of pre-treatments including particle size reduction, different alkali concentrations $(\mathrm{NaOH})$ and thermal. At the end of the pre-treatment stage, a slurry was produced. The slurry contained two phases. One phase contains the lignin, insoluble ash, and cellulose. The second phase is made up of solubilized material (typically the sugars required) (Slutier et al. 2016). FIS results are based on the amount of dry slurry remaining in relation total wet slurry produced. FIS is calculated using Equation 1 in Chapter 3. Ensuring FIS reproducibility \& repeatability is a key indicator for both quality controls in terms of ensuring removal of residual alkali, moisture and lignin, hence helping to control cost (Sluiter et al. 2016). As shown in Table 4.1, as the number of pre-treatment methods increased, the lowered amount of insoluble contents was recovered. For example, Batch 0 that was pretreated with $2 \% \mathrm{NaOH}$ in addition to thermal pre-treatment showed a lower amount of insoluble recovery $(\mathrm{FIS} \simeq 62.13 \%$ ) compared to Batch 1 which utilized only $2 \% \mathrm{NaOH}$ pretreatment $(\simeq$ FIS $68.25 \%)$. The same relationship was demonstrated with Batch $6(\mathrm{FIS} \simeq$ $66.06 \%$ ) which had a higher FIS value compared to Batch 7 (FIS $\simeq 61.26 \%$ ) which used $5 \%$ $\mathrm{NaOH}$ and thermal pre-treatment. The results are significant since the p-value calculated was less than 0.05 . 
Table 4.1 Summarises results for FIS obtained for different pre-treatment followed Table 3.3

\begin{tabular}{|l|l|}
\hline Sample Name & FIS (\%) \\
\hline Batch 0 & $62.13+/-1.00$ \\
\hline Batch 1 & $68.52+/-0.72$ \\
\hline Batch 2 & $66.66+/-1.75$ \\
\hline Batch 3 & $66.69+/-0.82$ \\
\hline Batch 4 & $66.90+/-0.96$ \\
\hline Batch 5 & $61.53+/-1.53$ \\
\hline Batch 6 & $66.06+/-0.19$ \\
\hline Batch 7 & $61.26+/-0.40$ \\
\hline Batch 8 & $60.69+/-0.30$ \\
\hline Batch 9 & $65.92+/-0.40$ \\
\hline Batch 10 & $68.2+/-0.14$ \\
\hline
\end{tabular}

From Table 4.1, it also shows that the severity of pre-treatment also has an effect on FIS. For example, Batch1 which incorporated $2 \% \mathrm{NaOH}$ had a higher FIS value compared to Batch 6. Meaning that the severity of pre-treatment has an effect on insoluble fraction. These results are significant since the $\mathrm{p}$-value was below 0.05 . The higher concentration of pre-treatment attacks the hemp structure by decreasing the crystallinity allowing for cellulose interaction and decreasing the FIS (Liu et al. 2015). In the fermentation process, lignin has the ability to inhibit bacterial growth. Lignin itself is an aromatic rigid polymer making it a complex matrix composed of phenolic compounds of phenyl propionic alcohols (Wunna et al. 2017). The matrix contains functional groups such as hydroxyl, methoxy, and carbonyl (Wunna et al. 2017). The purpose of alkali treatment pre-treatment is to disturb the lignin-hemicellulose bonds and solubilize the internal surface and bonds between lignin and hemicellulose, enhancing hemicellulose digestibility (Wunna et al 2017).

A study conducted by Wunna et al. (2017) investigated alkali pre-treatment effect on lignin removal found that alkali conditions such concentration have an effect on lignin removal (Wunna et al. 2017). As concentration increases the percentage of lignin removal increase while 
xylan production increases (Wunna et al. 2017). The higher concentration resulted in the ability to cleave lignin and glycosidic bonds that lead to decrease in crystallinity and increase swelling. The increasing concentration also results in saponification of acetyl and uronic esters bonds that allow enzymes access the cellulose (Chen et al. 2013). In a study conducted by Chen $e$ al. (2013), who investigated alkali pre-treatment parameters found that cellulose has a low reactivity to alkali solutions. Since alkali solutions such as $\mathrm{NaOH}$ neutralize the phenolics which are actually contained with lignin (Jaisamut et al. 2013; Wunna et al. 2017).

\subsubsection{PHB and Sugar Results}

Figure 4.1 represent s the pre-treatment effect on hydrolysis yield, PHB recovery and FIS. Examining this figure reveals that as the concentration of $\mathrm{NaOH}$ increases, the amount of hydrolysis yield and PHB recovery increases from 2 to 5\%. When correlating these results to FIS as shown in Figure 4.1, lower the FIS results demonstrated both a higher hydrolysis yield and PHB recovery. A study conducted by George et al. (2014) explained that the concentration of pre-treatment used is essential for hemp swelling which exposes the cellulose backbone, which influences the overall efficiency of enzymatic hydrolysis (George et al. 2014). That the pretreatment used affects the surface adhesion forces, de-fibrillation, and smoothness of hemp (George et al. 2014). 


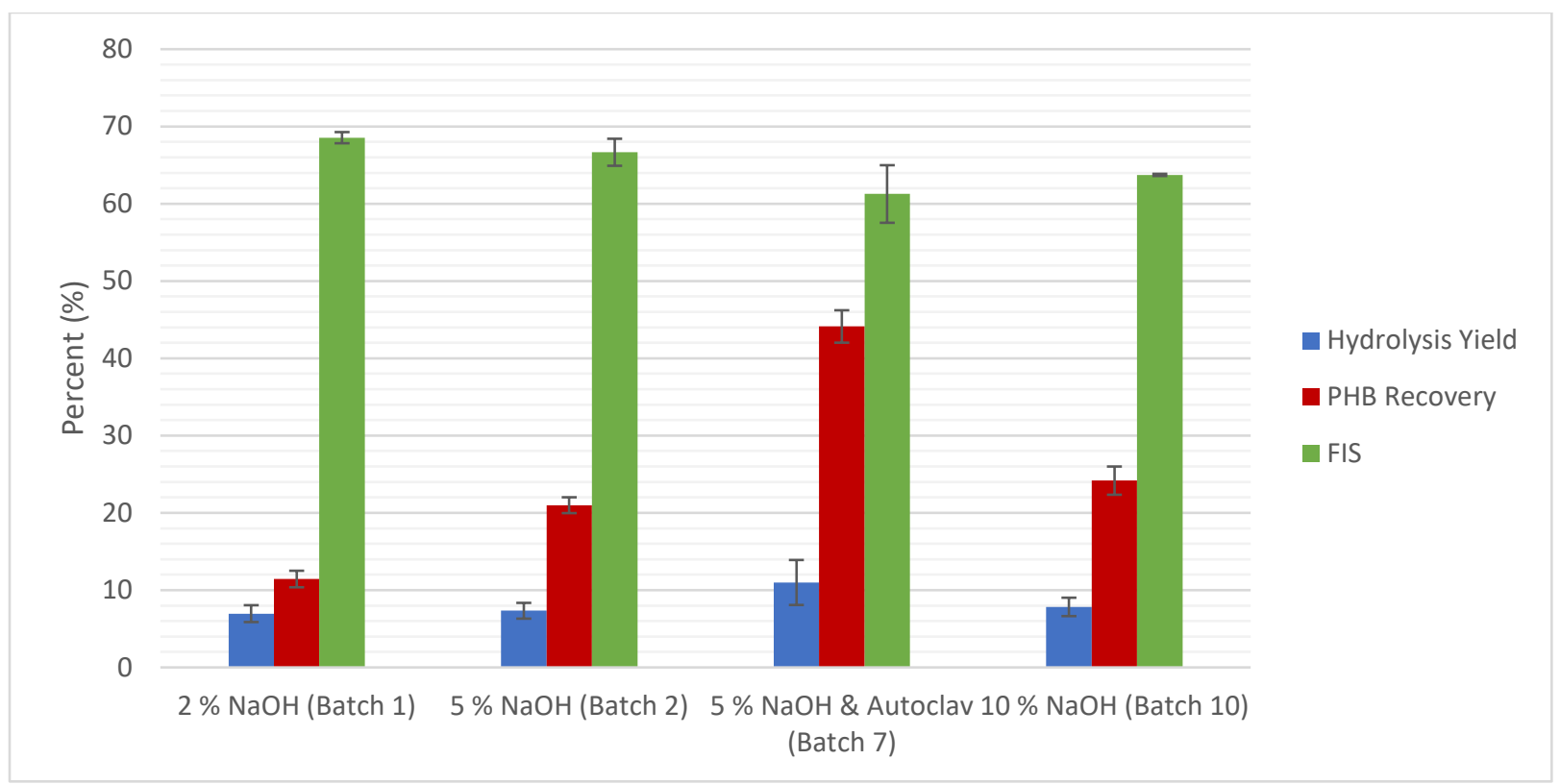

Figure 4.1Represents the pre-treatment effect on hydrolysis yield, PHB recovery and FIS. All samples were grinded as a first pre-treatment step.

Table 4.2 displays the results for the sugar concentration before and after fermentation. After examination of Table 4.2, it should be noted that after fermentation all sugars were consumed 72 hours. Batch 2 demonstrated a slightly higher hydrolysis yield compared to Batch 1. This higher hydrolysis corresponded to a higher PHB recovery. The higher concentration of $\mathrm{NaOH}$ used resulted in a higher removal of hemicellulose and lignin from the original pretreated hemp fibers that resulted in higher PHB recovery (Kabir et al. 2013). 
Table 4.2 Summary of sugar concentration before and after fermentation followed Table 3.3

\begin{tabular}{|c|c|c|c|c|c|c|c|c|}
\hline \multirow[t]{2}{*}{$\begin{array}{l}\text { Sample } \\
\text { Name }\end{array}$} & \multicolumn{2}{|c|}{$\begin{array}{l}\text { Sugar } \\
\text { Composition }\end{array}$} & \multirow{2}{*}{$\begin{array}{l}\text { Total } \\
\text { Sugars } \\
\text { (g/L) }\end{array}$} & \multirow{2}{*}{$\begin{array}{l}\text { Enzyme } \\
\text { Hydrolysis } \\
\text { Yield }(\%)- \\
\text { Before } \\
\text { Fermentation }\end{array}$} & \multirow{2}{*}{$\begin{array}{l}\text { Enzyme } \\
\text { Hydrolysis } \\
\text { Yield }(\%)- \\
\text { Before } \\
\text { Fermentation }\end{array}$} & \multirow{2}{*}{$\begin{array}{l}\text { Average } \\
\text { Wet } \\
\text { Mass } \\
\text { Produced } \\
\text { (grams) }\end{array}$} & \multirow{2}{*}{$\begin{array}{l}\text { Average } \\
\text { Dry } \\
\text { Mass } \\
\text { Produced } \\
\text { (grams) }\end{array}$} & \multirow[t]{2}{*}{$\begin{array}{l}\text { Yielc } \\
(\%)\end{array}$} \\
\hline & $\begin{array}{l}\text { Glucose } \\
(\mathrm{g} / \mathrm{L})\end{array}$ & $\begin{array}{l}\text { Xylose } \\
\text { (g/L) }\end{array}$ & & & & & & \\
\hline Batch 0 & 0.00 & - & 0.0 & 0.0 & 0.0 & 9.12 & 0.03 & 1.49 \\
\hline Batch 1 & 7.6 & 2.3 & 9.7 & 7.0 & 0.0 & 23.78 & 0.68 & 11.44 \\
\hline Batch 2 & 15.5 & 2.7 & 18.1 & 7.3 & 0.0 & 25.35 & 1.33 & 20.99 \\
\hline Batch 3 & 6.1 & 0.7 & 6.8 & 5.3 & 0.0 & 16.32 & 0.36 & 8.82 \\
\hline Batch 4 & 17.4 & 3.0 & 20.3 & 7.1 & 0.0 & 25.57 & 1.45 & 22.69 \\
\hline Batch 5 & 19.9 & 1.2 & 21.2 & 8.2 & 0.0 & 26.25 & 1.73 & 26.36 \\
\hline Batch 6 & 22.9 & 10.3 & 33.2 & 9.6 & 0.0 & 30.13 & 3.18 & 42.22 \\
\hline Batch 7 & 28.1 & 10.9 & 38.9 & 10.9 & 0.0 & 30.09 & 4.28 & 44.12 \\
\hline Batch 8 & 28.4 & 11.1 & 39.4 & 10.9 & 0.0 & 33.68 & 4.33 & 42.7 \\
\hline Batch 9 & 1.2 & 3.2 & 4.5 & 2.5 & 0.0 & 16.10 & 0.11 & 2.73 \\
\hline $\begin{array}{l}\text { Batch } \\
10 \\
\end{array}$ & 14.3 & 2.7 & 17.0 & 7.8 & 0.0 & 22.01 & 1.33 & 24.17 \\
\hline
\end{tabular}

When Batch 10was used, it demonstrated a higher hydrolysis yield and PHB recovery compared to Batch 1 and Batch 2. However, Batch 10 only produced less dry mass compared to BATCH2. When comparing FIS, Batch 10 had a higher FIS compared to Batch 2, which inversely affected the quantity of PHB produced. Between Batch 2 and Batch 10, the p-value was greater than 0.05 , there was no significant difference between the two. The combination of pre-treatments used ( $\mathrm{NaOH}$ with thermal treatments) provided a higher hydrolysis yield and PHB recovery compared to single pre-treatment use. FIS was also smaller. Demonstrating an overall better product compared to the other samples produced. These results are significant since the pvalue was less than 0.05 . 


\subsection{Enzyme Effectiveness}

\subsubsection{Enzyme Addition}

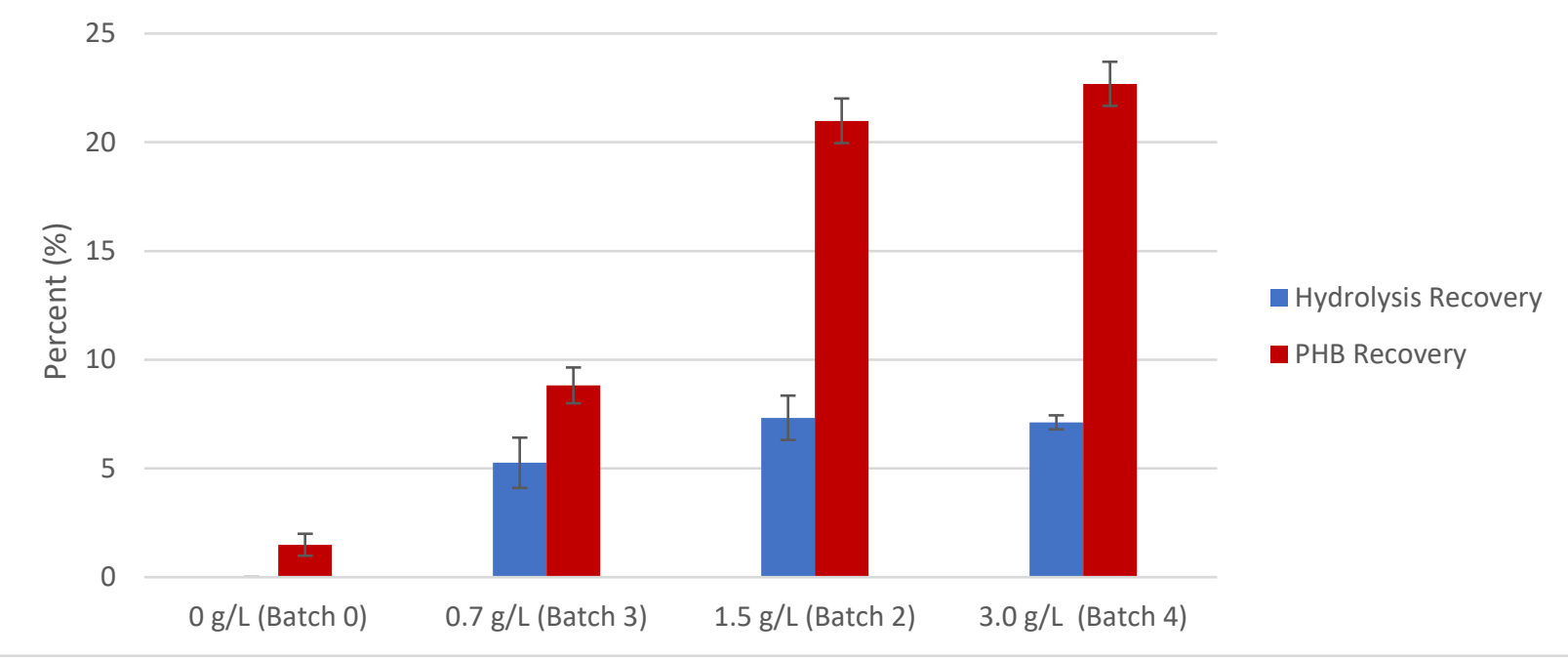

Figure 4.2 Represents the cellulase-T.ressi concentration effect in relation to hydrolysis recovery and $\mathrm{PHB}$ recovery

The most influential rate-limiting stage is the enzyme hydrolysis which converts the pretreated biomass into mono- and oligomeric sugars that can be used for further processing (Martin-Sampedro et al. 2013). Hence there is a need to improve our understanding of the interaction between enzymes and the hemp substrate. The goal is to develop a proficient enzyme hydrolysis method that is cost effective (Martin-Sampedro et al. 2013).

According to Table 4.2, samples that incorporated cellulase provided a higher total sugar value compared to Batch 9 which did not use cellulase. Cellulase has the ability to convert cellulose to glucose. Cellulase works by cleaving the $\beta-1,4$ glycosidic bonds. That is bonded to the glycosyl units. A widely accepted industrially for of cellulase is derived from Trichoderma reesi (T.reesi). The cellulose exoglycanase and endoglucanase of $\beta-1,4$ glycanase are made from specific units of complex proteins known as domains (Martin-Sampedro et al. 2013). The 
two main domains found within cellulase-T.reesi is catalytic domain and cellulase binding domain. The two forms are bonded to each other via peptide bonds (Martin-Sampedro et al. 2013).

The cellulase binding domain is used for interacting with insoluble cellulose surfaces, while the catalytic domain specializes in the hydrolysis reaction. Together these domains make cellulase - T.reesi a very reliable form of cellulase (Martin-Sampedro et al. 2013). A study conducted by Saratale et al. (2015), investigated enzyme dosage and its effect on PHB. Saratale et al. (2015) found that as enzyme dosage increase, enzyme hydrolysis also increased, but to a certain extent. They found from 5 to 10 FPU (Filter paperase activity) per gram, the enzyme hydrolysis increased, after 10 FPU / gram there was no significant effect in hydrolysis yield and PHB recovery (Saratale et al. 2015).

In this study, different concentrations of cellulase-T.reesi were investigated the optimized cellulase activity. Figure 4.2 Represents the cellulase-T.ressi concentration effect in relation to hydrolysis recovery and PHB recovery. Examining Figure 4.2, it was observed that $0 \mathrm{~g} / \mathrm{L}$ cellulase provided smaller hydrolysis recovery and PHB recovery followed by $0.7 \mathrm{~g} / \mathrm{L}$ then 1.5 $\mathrm{g} / \mathrm{L}$ and $3.0 \mathrm{~g} / \mathrm{L}$. The results are significant since the $\mathrm{p}$-value was less than 0.05 . There was also no significant difference between $1.5 \mathrm{~g} / \mathrm{L}$ and $3.0 \mathrm{~g} / \mathrm{L}$ (p-Value 0.37 ) in relation to enzyme hydrolysis yield which reflected in the PHB yield. The severity of pre-treatment was the same for Batch 2 and Batch 4 resulting in similar FIS values. The pretreated substrate was constant, while the dose of cellulase increased. Therefore, increasing the cellulase dosage to $1.5 \mathrm{~g} / \mathrm{L}$ is an effective way to produce PHB. 


\subsubsection{Enzyme Synergy Effect}

Low enzyme hydrolysis yield from cellulase and high-cost limit its ability on a large scale (Yang et al. 2018). Therefore, exploring different enzyme combinations is a method used to improve hydrolysis recovery and PHB recovery (Yang et al. 2018). A key issue in enzyme hydrolysis hemicellulose. Hemicellulose acts as a barrier that limits access to cellulose (Yang et al. 2018). An enzyme known as xylanase acts to disrupt biomass xylan structure within hemp (George et al. 2014; Yang et al. 2018). In this study, single and combination of enzymes were used. Combinations included Cellulase \& Novozymes 188 and Cellulase \& Novozymes $188 \&$ Xylanase. Each sample used $1.5 \mathrm{~g} / \mathrm{L}$ per enzyme. In Figure 4.3 display the effect from enzyme addition in relation to hydrolysis yield and PHB recovery. Figure 4.3 displays that three enzymes provided the highest hydrolysis yield and PHB recovery followed by Batch 5. (two enzymes) and Batch 2 (cellulase only). Batch 7 provided a higher total sugar of $38.9 \mathrm{~g} / \mathrm{L}$ compared to Batch 5 which was $21.2 \mathrm{~g} / \mathrm{L}$. This resulted in a higher Batch 7 average dry mass produced of $\approx 4.28$ grams while Batch 5 only provided $\approx 1.73$ grams. The results agree with Zhang et al. (2013). Zhang et al. (2013) investigated the number of enzyme addition during hydrolysis. They found that increasing the number of enzymes has a positive effect on enzyme hydrolysis. Increasing the enzyme hydrolysis amount, therefore improves PHB production (Zhang et al. 2013). 


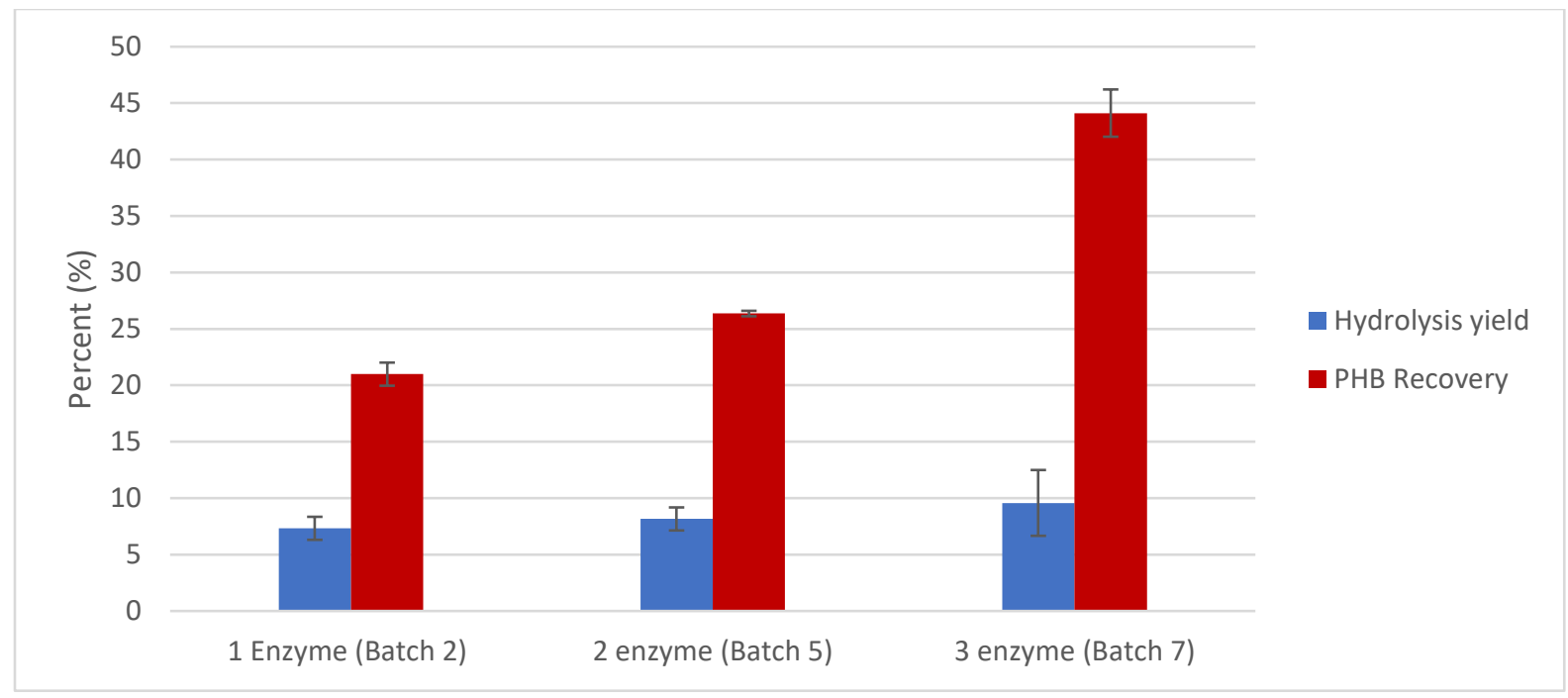

Figure 4.3 Represents the effect from enzyme addition in relation to hydrolysis yield and PHB recovery

The results are also in agreement with George et al. (2014) who studied the effects of enzymes on surface properties. Xylanase alone resulted in hemp surface roughness reduction, that exposed pre-treated hemp-cellulose backbone. Reducing the hemicellulose and lignin content resulted in a decrease in contact angle allowing better interaction between the enzyme and the pre-treated hemp. (Geroge et al. 2014).

\subsection{Extraction}

Figure 4.4 represents extraction with/ without sonification in relation to hydrolysis yield and PHB recovery. Batch 7 does not incorporate the sonification method while Batch 8 utilizes sonification. Examining Figure 4.4. it shows that the PHB recovery is better without sonification. The results are not significant since the $\mathrm{p}$ value $(0.86)$ is higher than 0.05 . These results are not in agreement with literature. 


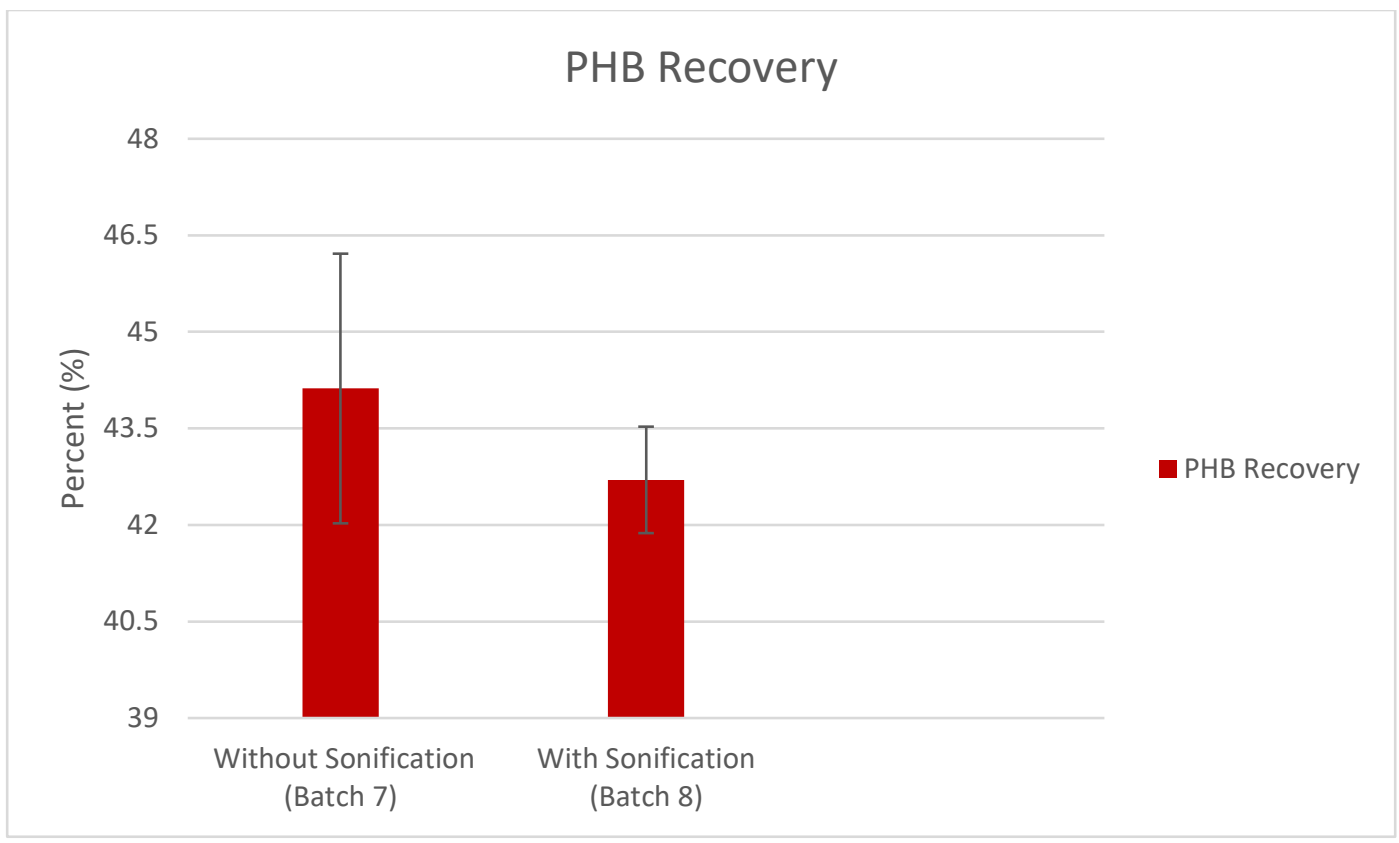

Figure 4.4 Represents extraction with/ without Sonification in relation to hydrolysis yield and PHB recovery

The results do not agree with Ishak et al. 2016. Ishak et al. (2016) investigated. sonification effect on solvent extraction on PHB. The goal in any PHB extraction is to reduce cost by reducing the time of extraction and organic solvent used. Therefore, the proficient mass transfer is needed to reach this goal (Ishak et al. 2016). An excellent method to enhance the mass transfer process in fluids is the use of PHB recovery is ultrasound irradiation (Ishak et al. 2016). Ultrasound irritation also known as sonification is used to produce rapid-recurrent pressure changes in the samples. Sonification is described as having two stages, the first being rarefaction and the other is compression stages. Rarefaction stage involves producing empty space within a solid object which produces gas and vapor microbubbles (Ishak et al. 2016). During the compression stage, the microbubbles will grow in size, once reaching an adequate size, the microbubbles will implode (intense turbulence) which would result in a shock wave that spreads through the polymer fluid (Ishak et al. 2016). These two stages overall produce effective mass 
transfer. Viscosity is also a critical parameter in regards to the success of sonification (Ishak et al. 2016). It should be noted that the viscosity of the polymer solution influences the microbubbles within the empty space within the polymer solution (Ishak et al. 2016). Organic solvents are less viscous (Ishak et al. 2016).

Ishak et al. (2016) studied different sonification parameters including duration and frequency. They found that sonification works best for 5 minutes under sonication frequency of $37 \mathrm{kHz}$. Ishak et al. (2016). Increased the viscosity of their polymer solution by adding a nonsolvent (hexane), therefore improving the polymer recovery. It should be noted the amount of nonsolvent is also critical, the too much nonorganic solvent can act as a precipitate (Ishak et al. 2016).

\subsection{Bacteria Influence on PHB}

\subsubsection{Total Sugar Concentration Profile}

Ralstonia eutropha is a well-known bacterium that can synthesize PHB from different renewable resources (Taguchi et al. 2003). Dahman et al. (2014) investigated production using wheat straw as the sole source using Ralstonia in two techniques. One known as separate hydrolysis and fermentation (SHF) and the other was glucose (as control). Dahman et al. (2014), study demonstrated a better production in terms of dry cell weight, hydrolysis yield and PHB with SHF compared to glucose control. For example, SHF produces $7.1 \mathrm{~g} / \mathrm{L}$ while glucose as a control produced $4.6 \mathrm{~g} / \mathrm{L}$. In this study, SHF was used to produce PHB. Figure 4.5 represents the total sugar concentration profile using the separate hydrolysis and fermentation. Examining this figure reveals that most sugar produced during pre-treatment was utilized with 48 to 72 hours, 
except sample Batch 7 and Batch 8. Batch 7 and Batch 8produced higher total sugar concentrations compared to other samples, therefore took, more time to consume. The higher sugar concentration of sugar had a fast consumption within the first 24 hours then slowed down after 48 hours until end of fermentation. After the fermentation process all sugar was consumed. This is in line with Dahman et al. (2014), where $98 \%$ of sugar was consumed after fermentation (Dahman et al. 2014).

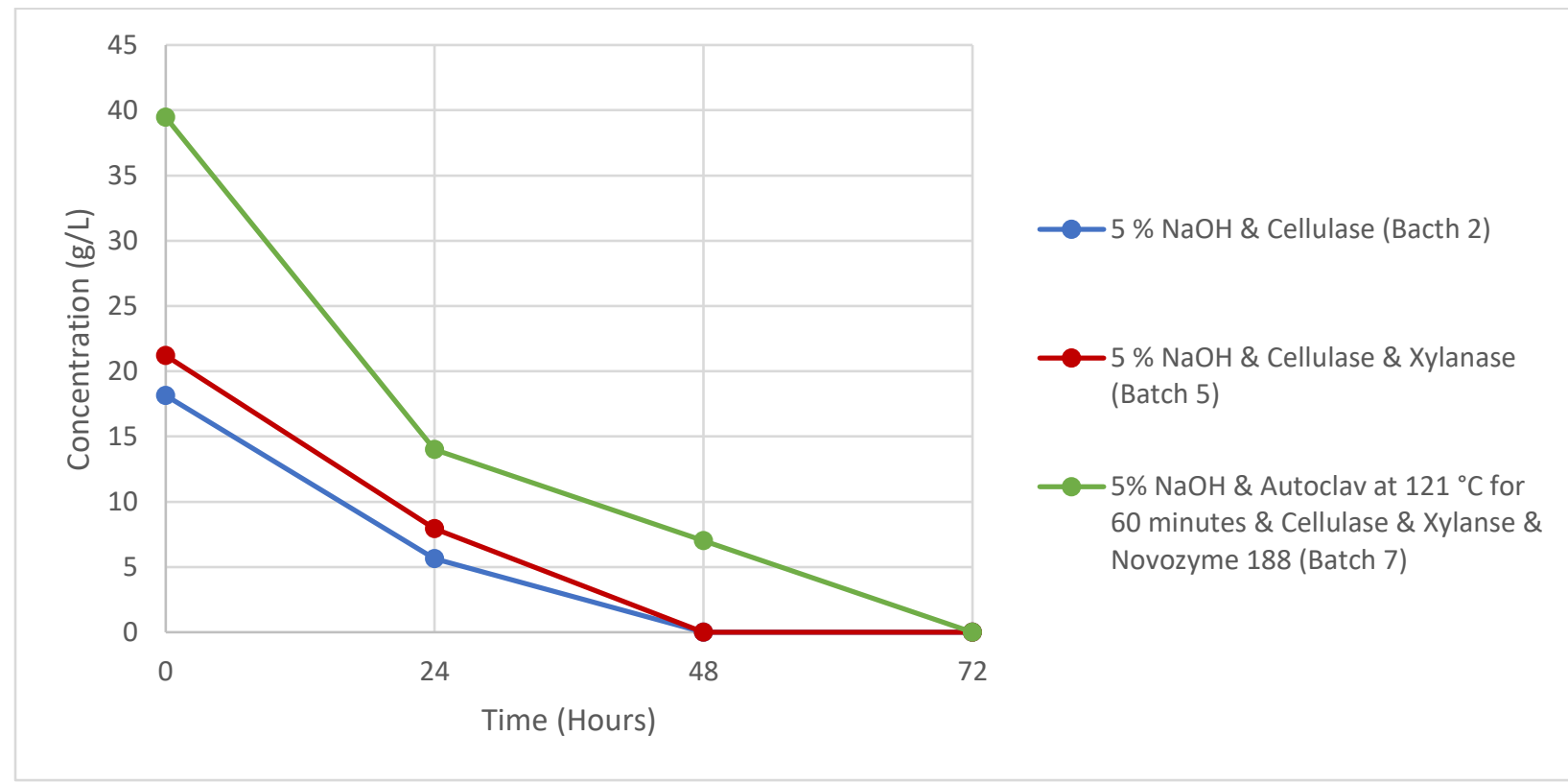

Figure 4.5 Represents the total sugar concentration profile using the separate hydrolysis and fermentation

\subsection{2. $\mathrm{pH}$ effect on $\mathrm{PHB}$}

PHB accumulates with Ralstonia eutropha cytoplasm as lipophilic inclusions (Macagnan et al. 2017). This occurs in two stages. The first stage is referred to as the inoculum phase. This is where bacterial cell growth occurs in the basal medium. The second phase is referred to as a polymer accumulation stage under nutrient limitation and high carbon concentration resulting in 
a high carbon to nutrient ratio. (Macagnan et al. 2017). The polymer accumulation stage works under nutritional limitation which acts as the driving force stage until a PHB saturation is achieved (Villano et al. 2014). Within fermentation time, Ralstonia is continuously exposure to both nutrients and carbon source (high substrate consumption), resulting in a bacterial growth response increasing achieving a high cell density while PHB production would decrease (Villano et al. 2010; Villano et al. 2014; Macagan et al. 2017). pH can manipulate PHA production. A study conducted by Oehmen et al. 2014 determine $\mathrm{pH}$ effect on biomass concentration and PHA storage response. Oehmen et al. (2014) pH controlled resulted in a higher PHA production rate. As $\mathrm{pH}$ rises, the microbial community increases along with the PHA storage yield (Oehmen et al. 2014). This is also in line with the work completed by Macagnan et al. (2017) who investigated adjusted/controlled $\mathrm{pH}$ in inoculum phase to optimize $\mathrm{PHB}$ production using Ralstonia and also found that $\mathrm{pH}$ has an effect in $\mathrm{PHB}$ production.

Literature also states that higher PHB production is linked to high $\mathrm{pH}$ values between 7.5 to 9 (Villano et al. 2010). Villano et al. (2010) also investigated the effect of $\mathrm{pH}$ on PHB production and found that PHA composition was strongly influenced by $\mathrm{pH}$. That $\mathrm{pH}$ control can lead to $48 \%$ increase in production. Villano et al. (2010) suggested that pH control can be used in different feedstock to improve PHB production (Villano et al. 2010). Base on literature, $\mathrm{pH}$ was controlled. Figure 4.6 shows the $\mathrm{pH}$ outcome on PHB production optimal conditions (Batch 7). Batch 1 was used as the control. As shown in Figure 4.6, after the addition of Ralstonia, there was no production in the first 48 hours, however, after 48 hours, granules started to form, indicating by the $\mathrm{pH}$ value above 7 . As illustrated in Figure 4.6 where the $\mathrm{pH}$ rose to $8.26+/-$ 0.33 after 72 hours, $9.39+/-0.31$ for 96 hours and $8.97+/-0.36$ for 120 hours. Increase in $\mathrm{pH}$ demonstrated a bioconversion during fermentation. Batch 1 on the other hand, produced after 72 
hours. The $\mathrm{pH}$ remained under 7 , indicating bacterial cell growth. This was indicated by a change in color of these samples. For example, after 48 hours Batch 7 change color from dark brown to light brown with white PHB lyophilic cells beginning to form. While Batch1 produced a darker shade of brown compared to Batch 7. Batch 1 starting producing PHB lyophilic cells after 72 hours. pH control had led to a $27 \%$ higher PHB yield in Batch 7 compared to Batch 1 .
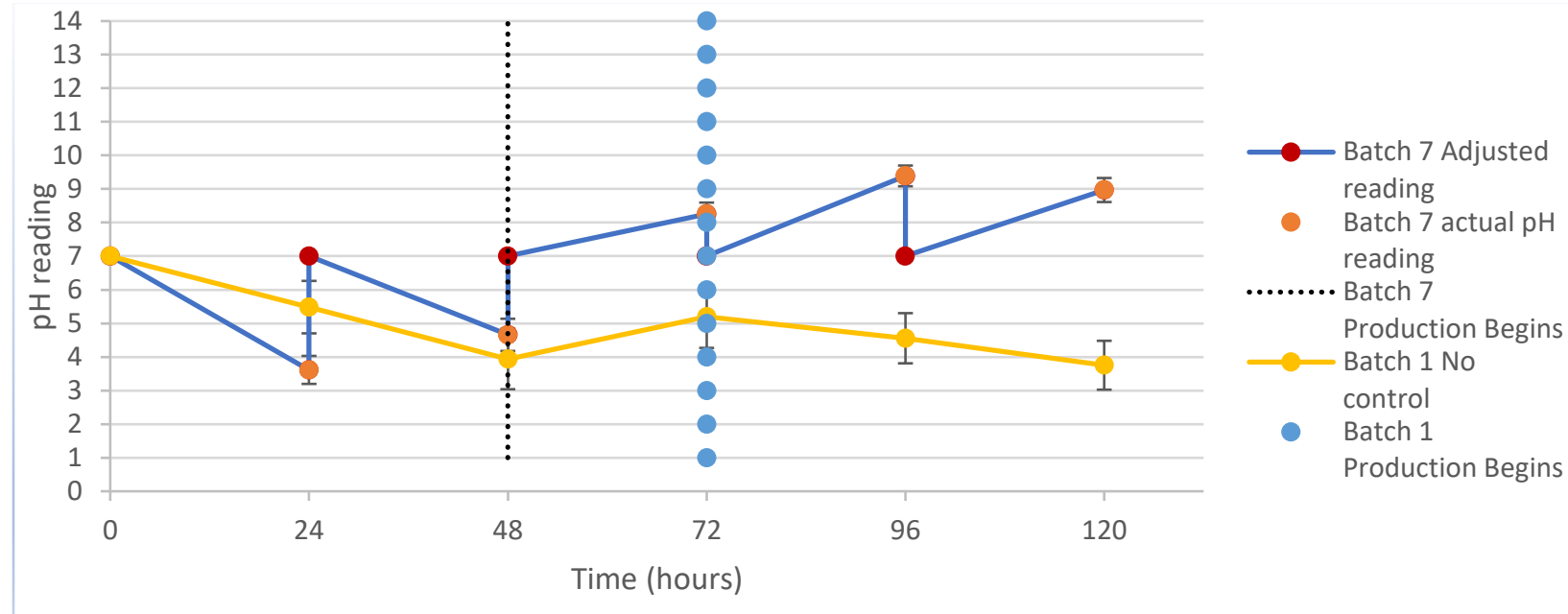

Figure 4.6 Represents the $\mathrm{pH}$ outcome on PHB production 


\section{Chapter 5 \\ Outlook \& Conclusion}

\subsection{Conclusion}

In this study, different pre-treatment and enzyme hydrolysis parameters were applied to Ralstonia eutropha to produce large amounts of PHB. Separate hydrolysis and fermentation were used with hemp as the renewable and sustainable feedstock. Pre-treatment effectiveness involved the use of physical pre-treatment along with different combinations of chemical and thermal forms of pre-treatment. In this study, the utilization of three pre-treatment methods (grinded $5 \% \mathrm{NaOH}$ - autoclave at $121^{\circ} \mathrm{C}$ for 60 minutes) led to higher disruption of the hemp lignin structure which led to higher removal of lignin enhancing hemicellulose digestibility and increase swelling. This led to lower FIS recovery of $\simeq 61 \%$. As a result, more cellulose was accessible for enzymes. Results were significant since the p-value was less than 0.05 .

Enzyme hydrolysis effectiveness was established by comparing enzyme dosage, enzyme type and enzyme synergy effect. Enzyme hydrolysis converts the pre-treatment biomass into simple sugars used for fermentation. Enzyme dosage was compared. It was found that enzyme using $1.5 \mathrm{~g} / \mathrm{L}$ is optimum for PHB production. By utilizing $1.5 \mathrm{~g} / \mathrm{L}$ for each enzyme hydrolysis yield produced $7.3 \%$ and PHB recovery produced $20.99 \%$ which represented a significantly better results compared to other dosage ( 0 to $3 \mathrm{~g} / \mathrm{L}$ ) studied. The dosage represents optimum conditions for cellulase to bind to substrate for simple sugar conversion. The combination of enzymes was also investigated. The use of three enzymes which include $1.5 \mathrm{~g} / \mathrm{L}$ of each cellulase, xylanase Novozyme led to higher hydrolysis yield of $10.9 \%$ and PHB recovery of 44.17. 
$\mathrm{pH}$ control between Batch1 and Batch 7 was investigated. Batch 1 was studied using no $\mathrm{pH}$ control, while Batch $7 \mathrm{pH}$ was adjusted every 24 hours. Adjusting the $\mathrm{pH}$ lead to overall increase in $27 \%$ PHB yield. Finally, an extraction comparison in relation to sonification was also conducted. Sonification in this study was unable to significantly improve PHB production. Future work would require a more durable sonification apparatus that is able to work with PHB.

The combination of pre-treatment (grinded \& $5 \% \mathrm{NaOH} \&$ autoclave for 60 minutes) with the use of three enzymes (cellulase, xylanase, and Novozyme) led to higher total sugar concentration $\simeq 40 \mathrm{~g} / \mathrm{L}$ and higher PHB production yielding $\simeq 43 \%$. The use of this parameters can be implemented for further commercialization in an attempt to reduce cost. Based on the literature, future work needs to incorporate a form of sonification to further improve processing capabilities.

\subsection{Outlook and Future Recommendations}

PHB is a conventional biodegradable plastic with a high melting point $\left(\simeq 180^{\circ} \mathrm{C}\right)$, glass transition temperature of $\simeq 5^{\circ} \mathrm{C}$ while exhibiting a high crystalline characteristic (Garcia-Garcia et al. 2016) (Abdelwahab et al. 2012). Due to PHB high crystalline characteristic and high melting point, PHB is fragile (literature described as "brittle") and exhibits difficult ion thermal processing that prevents its use in different applications (Anabukerasu et al. 2015).

- PHB Blending to improve processability results

- Investigation into low environmental impact plasticizers

- Environmentally friendly extraction methods

- Genetically modify Ralstonia eutropha can be used to improve PHB productivity 
- FIS compositional Analysis

- Bioreactor 


\section{Appendix A}

Table A.1 Represents the equipment used in this study

\begin{tabular}{|l|l|l|}
\hline Equipment Model & Serial Number & Manufacture \\
\hline $\begin{array}{l}\text { 1200 Infinity HPLC } \\
\text { Apparatus }\end{array}$ & $\begin{array}{l}\text { 1260 Quad Pump } \\
\text { (DEAB805754) } \\
\text { TCC : DEACN12554 } \\
\text { RID: DEAA602224 }\end{array}$ & Agilent Technologies \\
\hline $\begin{array}{l}\text { 51BL32 Commercial } \\
\text { Blender }\end{array}$ & 021115 & Waring \\
\hline AB104-S Balance & 1129212158 & Mettler-Toledo \\
\hline accuSpin 400 Centrifuge & 40894047 & Fisher Scientific \\
\hline $\begin{array}{l}\text { Analog Vortex Mixer VM- } \\
\text { 3000 }\end{array}$ & $58916-121$ & VWR \\
\hline Corning PC-353 Stirrer & N/a & Cole Palmer \\
\hline Despatch Industrial Oven & XRCC 002991 & Xerox \\
\hline JMP Fumehood & 001 & Jamestown Metal Products \\
\hline $\begin{array}{l}\text { LabGard Class II, Type A2 } \\
\text { Biological Cabinet }\end{array}$ & 124021061808 & NUAIRE \\
\hline MaxQ 2000 CO Shaker & 1410080400819 & Thermo Scientific \\
\hline MaxQ 4450 Shaker & 1413100353224 & Thermo Scientific \\
\hline $\begin{array}{l}\text { MLS-3780 Laboratory } \\
\text { Autoclav }\end{array}$ & 731280 & SANYO \\
\hline PB1507-L Balance & 1129231716 & Mettler-Toledo \\
\hline $\begin{array}{l}\text { Revco Elite Plus Freezer } \\
\text { (ULT2586-6-A42) }\end{array}$ & 0125679201080623 & Thermo Scientific \\
\hline Seven Easy pH & 1229525475 & Mettler-Toledo \\
\hline $\begin{array}{l}\text { SP0810 Packed Column for } \\
\text { HPLC }\end{array}$ & H912040 & Shodex \\
\hline $\begin{array}{l}\text { UP200Ht Ultrasonic } \\
\text { processor }\end{array}$ & 35101570910 & Hielscher \\
\hline VMS-C7S1 Hot plate & 07.162197 & VMR \\
\hline
\end{tabular}




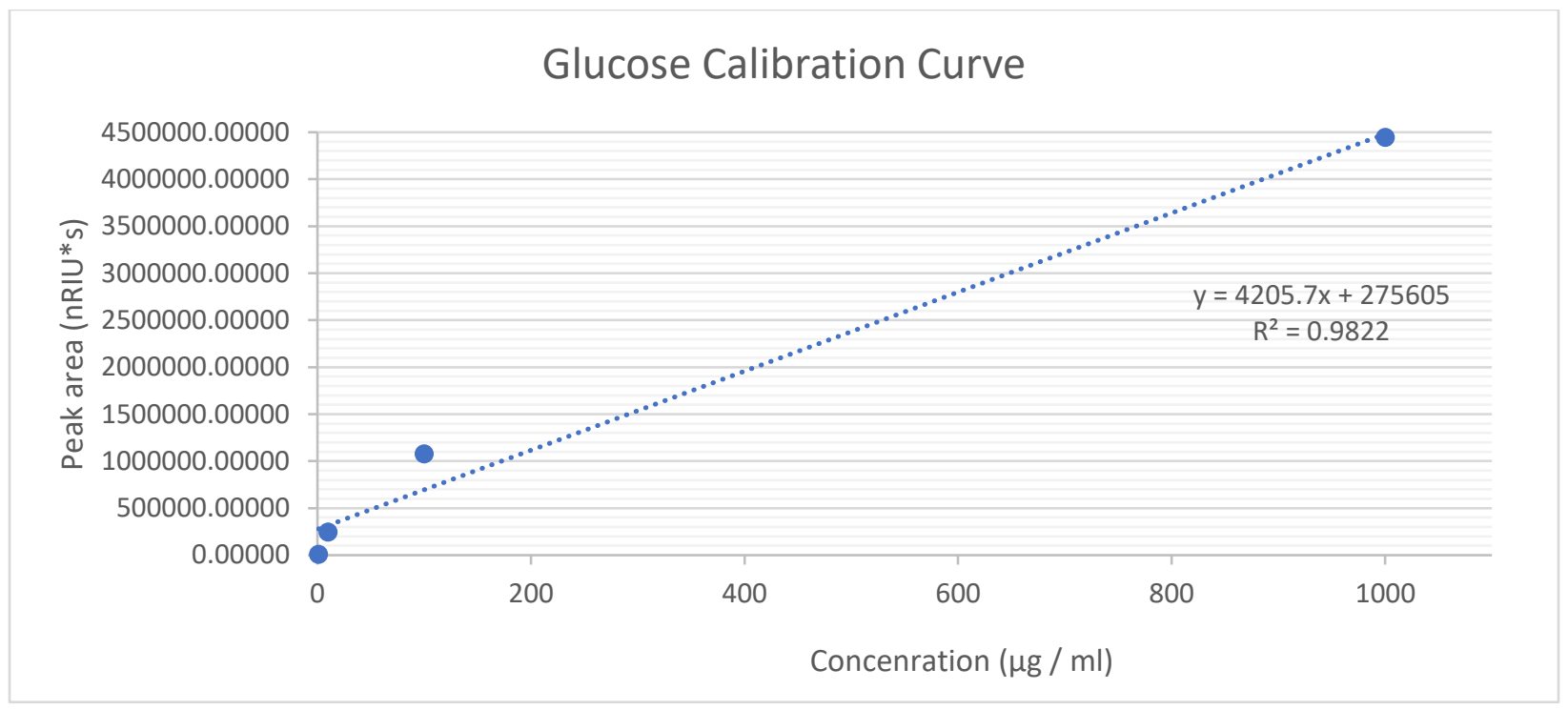

Figure A.1 Glucose Calibration Curve for known concentrations

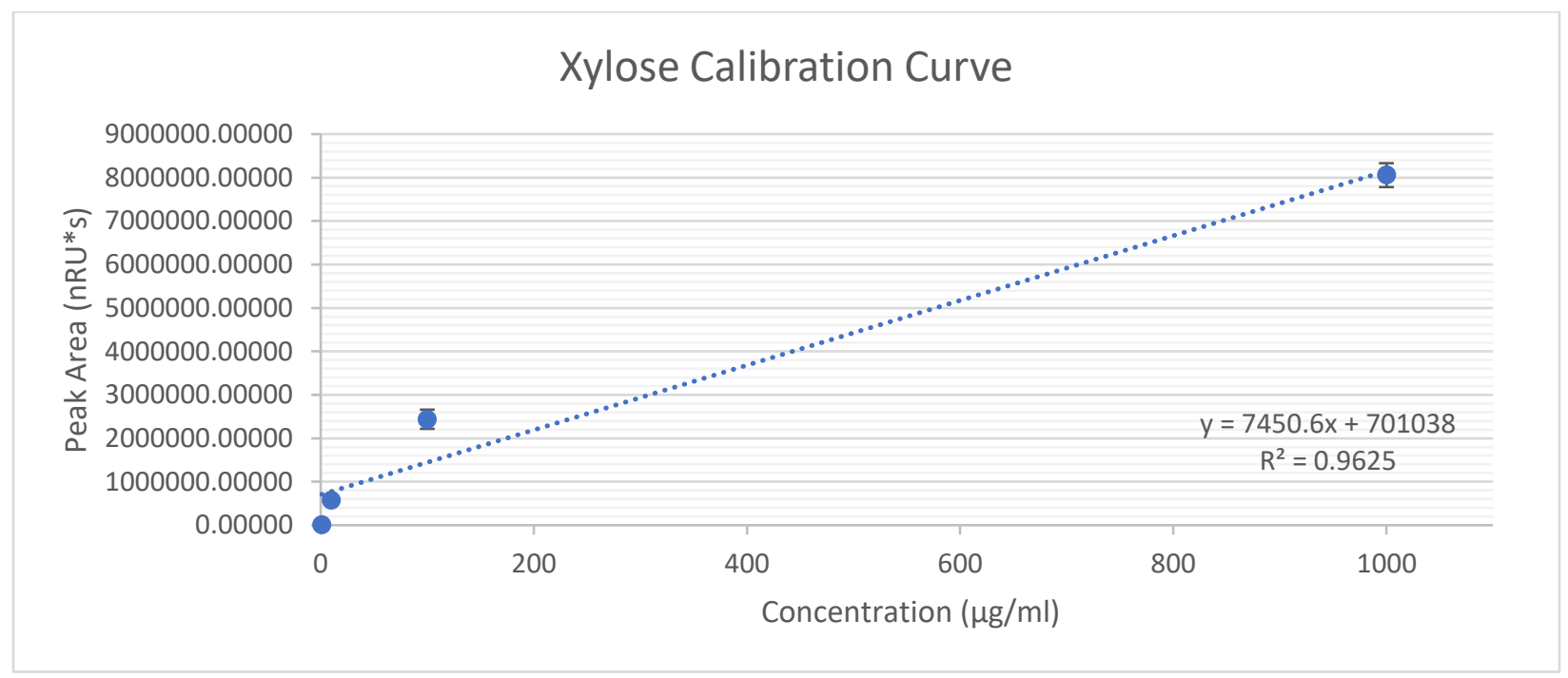

Figure A.2 Xylose Calibration Curve for known concentrations 
Table A.2 Shows FIS observations and corresponding average and standard deviation

\begin{tabular}{|l|l|l|l|l|l|l|}
\hline $\begin{array}{l}\text { Sample } \\
\text { Name }\end{array}$ & $\begin{array}{l}\text { FIS } \\
\text { Observation } \\
(\%)\end{array}$ & $\begin{array}{l}\text { FIS } \\
\text { Observation } \\
2(\%)\end{array}$ & $\begin{array}{l}\text { FIS } \\
\text { Observation } \\
3(\%)\end{array}$ & $\begin{array}{l}\text { Average FIS } \\
(\%)\end{array}$ & $\begin{array}{l}\text { Standard } \\
\text { Deviation }\end{array}$ & $\begin{array}{l}\text { Relative } \\
\text { Standard } \\
\text { Deviation } \\
(\%)\end{array}$ \\
\hline AC0 & 62.14 & 63.13 & 61.11 & 62.13 & 1.01 & 1.6 \\
\hline AC1 & 68.30 & 69.32 & 67.93 & 68.52 & 0.72 & 1.1 \\
\hline AC2 & 65.73 & 65.57 & 68.67 & 66.66 & 1.75 & 2.6 \\
\hline AC3 & 66.35 & 67.63 & 66.09 & 66.69 & 0.82 & 1.2 \\
\hline AC4 & 66.14 & 67.98 & 66.57 & 66.90 & 0.96 & 1.4 \\
\hline AC5 & 62.39 & 59.77 & 62.43 & 61.53 & 1.53 & 2.5 \\
\hline AC6 & 66.05 & 65.87 & 66.25 & 66.06 & 0.19 & 0.3 \\
\hline AC7 & 61.45 & 60.81 & 61.54 & 61.26 & 0.40 & 0.7 \\
\hline AC8 & 60.64 & 60.36 & 61.07 & 60.69 & 0.36 & 0.6 \\
\hline AC9 & 66.19 & 65.40 & 66.17 & 65.92 & 0.45 & 0.7 \\
\hline AC10 & 68.07 & 68.35 & 68.17 & 68.20 & 0.14 & 0.2 \\
\hline
\end{tabular}

Table A.3 Represents the glucose RID reading after enzyme hydrolysis

\begin{tabular}{|l|l|l|l|l|l|l|}
\hline $\begin{array}{l}\text { Sample } \\
\text { Name }\end{array}$ & $\begin{array}{l}\text { Reading 1 } \\
\text { (nRIU*s) }\end{array}$ & $\begin{array}{l}\text { Reading 2 } \\
\text { (nRIU*s) }\end{array}$ & $\begin{array}{l}\text { Reading 3 } \\
\text { (nRIU*s) }\end{array}$ & $\begin{array}{l}\text { Calculated } \\
\text { Average (g/L) }\end{array}$ & $\begin{array}{l}\text { Standard } \\
\text { Deviation }\end{array}$ & $\begin{array}{l}\text { Relative } \\
\text { Standard } \\
\text { Deviation } \\
\text { (\%) }\end{array}$ \\
\hline AC0 & 309250 & 309654 & 311255 & 8.2 & 0.25 & 3.0 \\
\hline AC1 & 308830 & 307273 & 306979 & 7.6 & 0.24 & 3.2 \\
\hline AC2 & 339681 & 341447 & 340666 & 15.5 & 0.21 & 1.4 \\
\hline AC3 & 302521 & 300419 & 301259 & 6.1 & 0.25 & 4.1 \\
\hline AC4 & 350802 & 346917 & 348218 & 17.4 & 0.47 & 2.7 \\
\hline AC5 & 358364 & 360429 & 359733 & 19.9 & 0.25 & 1.3 \\
\hline AC6 & 372373 & 372317 & 370938 & 22.9 & 0.19 & 0.8 \\
\hline AC7 & 394617 & 392750 & 393364 & 28.1 & 0.23 & 0.8 \\
\hline AC8 & 393737 & 395698 & 395187 & 28.4 & 0.24 & 0.8 \\
\hline AC9 & 280794 & 281913 & 279600 & 1.2 & 0.28 & 23.3 \\
\hline AC10 & 337134 & 335002 & 334909 & 14.3 & 0.30 & 2.1 \\
\hline
\end{tabular}


Table A.4 Represents the xylose RID reading after enzyme hydrolysis

\begin{tabular}{|l|l|l|l|l|l|l|}
\hline $\begin{array}{l}\text { Sample } \\
\text { Name }\end{array}$ & $\begin{array}{l}\text { Reading 1 } \\
\text { (nRIU*s) }\end{array}$ & $\begin{array}{l}\text { Reading 2 } \\
\text { (nRIU*s) }\end{array}$ & $\begin{array}{l}\text { Reading 3 } \\
\text { (nRIU*s) }\end{array}$ & $\begin{array}{l}\text { Calculated } \\
\text { Average (g/L) }\end{array}$ & $\begin{array}{l}\text { Standard } \\
\text { Deviation }\end{array}$ & $\begin{array}{l}\text { Relative } \\
\text { Standard } \\
\text { Deviation } \\
(\%)\end{array}$ \\
\hline AC0 & - & - & - & 0.00 & 0.0 & 0.0 \\
\hline AC1 & 717578.0 & 719441.0 & 717876.0 & 2.32 & 0.13 & 5.6 \\
\hline AC2 & 719344.0 & 720558.0 & 722875.0 & 2.67 & 0.24 & 9.0 \\
\hline AC3 & 707490.0 & 706827.0 & 704555.0 & 0.70 & 0.21 & 30.0 \\
\hline AC4 & 723296.0 & 723389.0 & 723483.0 & 3.00 & 0.01 & 0.3 \\
\hline AC5 & 709498.0 & 711391.0 & 710144.0 & 1.25 & 0.13 & 10.4 \\
\hline AC6 & 776464.0 & 778995.0 & 777977.0 & 10.30 & 0.17 & 1.7 \\
\hline AC7 & 783898.0 & 779855.0 & 782678.0 & 10.89 & 0.28 & 2.6 \\
\hline AC8 & 781069.0 & 786392.0 & 783855.0 & 11.10 & 0.36 & 3.2 \\
\hline AC9 & 724477.0 & 725312.0 & 725873.0 & 3.25 & 0.09 & 2.8 \\
\hline AC10 & 720069.0 & 721632.0 & 721741.0 & 2.70 & 0.13 & 4.8 \\
\hline
\end{tabular}

Table A.5 Glucose Reading for each sample during Fermentation

\begin{tabular}{|c|c|c|c|c|c|c|}
\hline \multicolumn{7}{|l|}{ AC2 } \\
\hline Time & $\begin{array}{l}\text { Reading } 1 \\
\left(\mathrm{nRIU}{ }^{*} \mathrm{~s}\right)\end{array}$ & $\begin{array}{l}\text { Reading } 2 \\
\left(\mathrm{nRIU}{ }^{*} \mathrm{~s}\right)\end{array}$ & $\begin{array}{l}\text { Reading } 3 \\
\left(n \text { IIU*s) }^{*} \mathrm{~s}\right.\end{array}$ & $\begin{array}{l}\text { Calculated } \\
\text { Average (g/L) }\end{array}$ & $\begin{array}{l}\text { Standard } \\
\text { Deviation }\end{array}$ & $\begin{array}{l}\text { Relative } \\
\text { Standard } \\
\text { Deviation } \\
(\%)\end{array}$ \\
\hline 0 & 339681 & 341447 & 340666 & 15.5 & 0.21 & 1.4 \\
\hline 24 & 299313 & 299178 & 299409 & 5.6 & 0.03 & 0.5 \\
\hline 48 & 0 & 0 & 0 & 0.0 & 0.00 & 0.0 \\
\hline 72 & 0 & 0 & 0 & 0.0 & 0.00 & 0.0 \\
\hline \multicolumn{7}{|l|}{ AC5 } \\
\hline 0 & 358364 & 360429 & 359733 & 19.9 & 0.25 & 1.3 \\
\hline 24 & 309478 & 309074 & 308325 & 7.9 & 0.14 & 1.8 \\
\hline 48 & 0 & 0 & 0 & 0.0 & 0.00 & 0 \\
\hline 72 & 0 & 0 & 0 & 0.0 & 0.00 & 0 \\
\hline \multicolumn{7}{|l|}{ AC7 } \\
\hline 0 & 394617 & 392750 & 393364 & 28.1 & 0.23 & 0.8 \\
\hline 24 & 313037 & 313596 & 313335 & 9.0 & 0.07 & 0.8 \\
\hline 48 & 0 & 0 & 0 & 0.0 & 0.00 & 0 \\
\hline 72 & 0 & 0 & 0 & 0.0 & 0.00 & 0 \\
\hline
\end{tabular}


Table A.6 Xylose reading for each sample during fermentation

\begin{tabular}{|l|l|l|l|l|l|l|}
\hline AC2 & $\begin{array}{l}\text { Reading 1 } \\
\text { (nRIUs) }\end{array}$ & $\begin{array}{l}\text { Reading 2 } \\
\text { (nRIU*s) }\end{array}$ & $\begin{array}{l}\text { Reading 3 } \\
\text { (nRIU*s) }\end{array}$ & $\begin{array}{l}\text { Calculated } \\
\text { Average (g/L) }\end{array}$ & $\begin{array}{l}\text { Standard } \\
\text { Deviation }\end{array}$ & $\begin{array}{l}\text { Relative } \\
\text { Standard } \\
\text { Deviation } \\
\text { (\%) }\end{array}$ \\
\hline 0 & 719344 & 720558 & 722875 & 2.7 & 0.24 & 8.9 \\
\hline 24 & 0 & 0 & 0 & 0.0 & 0.00 & 0.0 \\
\hline 48 & 0 & 0 & 0 & 0.0 & 0.00 & 0.0 \\
\hline 72 & 0 & 0 & 0 & 0.0 & 0.00 & 0.0 \\
\hline AC5 & 709498 & 711391 & 710144 & 1.2 & 0.13 & 10.8 \\
\hline 0 & 0 & 0 & 0 & 0.0 & 0.00 & 0.0 \\
\hline 24 & 0 & 0 & 0 & 0.0 & 0.00 & 0.0 \\
\hline 48 & 0 & 0 & 0 & 0.0 & 0.00 & 0.0 \\
\hline 72 & 783898 & 779855 & 782678 & 10.9 & 0.28 & 2.6 \\
\hline AC7 & 729742 & 734321 & 732827 & 4.2 & 0.31 & 7.4 \\
\hline 0 & 0 & 0 & 0 & 0.0 & 0.00 & 0.0 \\
\hline 24 & 0 & 0 & 0 & 0.0 & 0.00 & 0.0 \\
\hline 48 & 0 & 0 &
\end{tabular}

Table A.7 Represents wet mass produced and corresponding average and standard deviation

\begin{tabular}{|l|l|l|l|l|l|l|}
\hline $\begin{array}{l}\text { Sample } \\
\text { Name }\end{array}$ & Reading 1 & Reading 2 & Reading 3 & $\begin{array}{l}\text { Calculated } \\
\text { Average }\end{array}$ & $\begin{array}{l}\text { Standard } \\
\text { Deviation }\end{array}$ & $\begin{array}{l}\text { Relative } \\
\text { Standard } \\
\text { Deviation } \\
\text { (\%) }\end{array}$ \\
\hline AC0 & 9.15 & 10.12 & 8.10 & 9.12 & 1.01 & 11.1 \\
\hline AC1 & 23.09 & 23.56 & 24.70 & 23.78 & 0.83 & 3.5 \\
\hline AC2 & 25.68 & 24.33 & 26.04 & 25.35 & 0.90 & 3.6 \\
\hline AC3 & 15.99 & 16.42 & 16.57 & 16.33 & 0.30 & 1.8 \\
\hline AC4 & 25.43 & 25.62 & 25.65 & 25.57 & 0.12 & 0.5 \\
\hline AC5 & 26.28 & 27.46 & 25.02 & 26.25 & 1.22 & 4.6 \\
\hline AC6 & 29.32 & 31.01 & 30.06 & 30.13 & 0.85 & 2.8 \\
\hline AC7 & 30.14 & 28.43 & 31.69 & 30.09 & 1.63 & 5.4 \\
\hline AC8 & 30.87 & 33.96 & 36.21 & 33.68 & 2.68 & 8.0 \\
\hline AC9 & 15.73 & 15.99 & 16.57 & 16.10 & 0.43 & 2.7 \\
\hline AC10 & 22.73 & 20.80 & 22.50 & 22.01 & 1.05 & 4.8 \\
\hline
\end{tabular}


Table A.8 Represents ACl pH reading and corresponding average and standard deviation

\begin{tabular}{|l|l|l|l|l|l|l|}
\hline $\begin{array}{l}\text { Sample } \\
\text { Name }\end{array}$ & Reading 1 & Reading 2 & Reading 3 & Average & $\begin{array}{l}\text { Standard } \\
\text { Deviation }\end{array}$ & $\begin{array}{l}\text { Relative } \\
\text { Standard } \\
\text { Deviation } \\
(\%)\end{array}$ \\
\hline 0 & 7 & 7 & 7 & 7 & 0 & 0.0 \\
\hline 24 & 5.63 & 4.64 & 6.18 & 5.48 & 0.78 & 14.2 \\
\hline 48 & 3.72 & 3.17 & 4.93 & 3.94 & 0.90 & 22.9 \\
\hline 72 & 5.16 & 6.15 & 4.29 & 5.20 & 0.93 & 17.9 \\
\hline 96 & 4.5 & 5.33 & 3.84 & 4.56 & 0.75 & 16.4 \\
\hline 120 & 4.58 & 3.47 & 3.21 & 3.75 & 0.73 & 19.4 \\
\hline
\end{tabular}

Table A.9 Represents AC7 pH reading and corresponding average and standard deviation

\begin{tabular}{|l|l|l|l|l|l|l|}
\hline $\begin{array}{l}\text { Sample } \\
\text { Name }\end{array}$ & Reading 1 & Reading 2 & Reading 3 & Average & $\begin{array}{l}\text { Standard } \\
\text { Deviation }\end{array}$ & $\begin{array}{l}\text { Relative } \\
\text { Standard } \\
\text { Deviation } \\
\text { (\%) }\end{array}$ \\
\hline 0 & 7 & 7 & 7 & 7.00 & 0.00 & 0 \\
\hline 24 & 3.22 & 3.57 & 4.05 & 3.61 & 0.42 & 11.6 \\
\hline 48 & 4.22 & 4.58 & 5.17 & 4.66 & 0.48 & 10.3 \\
\hline 72 & 8.23 & 8.61 & 7.94 & 8.26 & 0.34 & 4.1 \\
\hline 96 & 9.34 & 9.72 & 9.11 & 9.39 & 0.31 & 3.3 \\
\hline 120 & 8.57 & 9.08 & 9.26 & 8.97 & 0.36 & 4.0 \\
\hline
\end{tabular}




\section{References}

Abajo, C., Hidalgo, J., Jiménez-Morales1, A. and Torralba, J. (2013). Feedstock development based on eco-friendly binder system for powder injection molding. Feedstock development based on eco-friendly binder system for powder injection molding, Euro PM2013, pp.1-8.

Abajo, C., Jiménez-Morales, A. and Torralba, J. (2015). New processing route for $\mathrm{ZrSiO} 4$ by powder injection moulding using an eco-friendly binder system. Boletín de la Sociedad Española de Cerámica y Vidrio, 54(3), pp.93-100.

Abdelwahab, M., Flynn, A., Chiou, B., Imam, S., Orts, W. and Chiellini, E. (2012). Thermal, mechanical and morphological characterization of plasticized PLA-PHB blends. Polymer Degradation and Stability, 97(1), pp.1822-1828.

Adelopo, A., Haris, P., Alo, B., Huddersman, K. and Jenkins, R. (2018). Multivariate analysis of the effects of age, particle size and landfill depth on heavy metals pollution content of closed and active landfill precursors. Waste Management, 78(1), pp.227-237.

Akaraonye, E., Keshavarz, T. and Roy, I. (2010). Production of polyhydroxyalkanoates: the future green materials of choice. Journal of Chemical Technology \& Biotechnology, 85(6), pp.732-743.

Akiyama, M., Tsuge, T. and Doi, Y. (2003). Environmental life cycle comparison of polyhydroxyalkanoates produced from renewable carbon resources by bacterial fermentation. Polymer Degradation and Stability, 80(1), pp.183-194. 
Alam, O., Billah, M. and Yajie, D. (2018). Characteristics of plastic bags and their potential environmental hazards. Resources, Conservation and Recycling, 132, pp.121-129.

Anbukarasu, P., Sauvageau, D. and Elias, A. (2015). Tuning the properties of polyhydroxybutyrate films using acetic acid via solvent casting. Scientific Reports, 5(1), pp.1-15.

Arrieta, M., López, J., López, D., Kenny, J. and Peponi, L. (2015). Development of flexible materials based on plasticized electrospun PLA-PHB blends: Structural, thermal, mechanical and disintegration properties. European Polymer Journal, 73, pp.433-446.

Arrieta, M., López, J., Rayón, E. and Jiménez, A. (2014). Disintegrability under composting conditions of plasticized PLA-PHB blends. Polymer Degradation and Stability, 108(1), pp.307318.

Avery-Gomm, S., Provencher, J., Liboiron, M., Poon, F. and Smith, P. (2018). Plastic pollution in the Labrador Sea: An assessment using the seabird northern fulmar Fulmarus glacialis as a biological monitoring species. Marine Pollution Bulletin, 127, pp.817-822.

Azizi, N., Najafpour, G. and Younesi, H. (2017). Acid pretreatment and enzymatic saccharification of brown seaweed for polyhydroxybutyrate (PHB) production using Cupriavidus necator. International Journal of Biological Macromolecules, 101(1), pp.10291040.

Ballesteros, I., Negro, M., Oliva, J., Cabanas, A., Manzanares, P. and Ballesteros, M. (2006). Ethanol Production From Steam-Explosion Pretreated Wheat Straw. Applied Biochemistry and Biotechnology, 130(1), pp.496-508. 
Bidoki, S. and Wittlinger, R. (2010). Environmental and economical acceptance of polyvinyl chloride (PVC) coating agents. Journal of Cleaner Production, 18(3), pp.219-225.

Bour, A., Haarr, A., Keiter, S. and Hylland, K. (2018). Environmentally relevant microplastic exposure affects sediment-dwelling bivalves. Environmental Pollution, 236, pp.652-660.

Breyer, S., Mekhitarian, L., Rimez, B. and Haut, B. (2017). Production of an alternative fuel by the co-pyrolysis of landfill recovered plastic wastes and used lubrication oils. Waste Management, 60(1), pp.363-374.

Brodeur, G., Yau, E., Badal, K., Collier, J., Ramachandran, K. and Ramakrishnan, S. (2011). Chemical and Physicochemical Pretreatment of Lignocellulosic Biomass: A Review. Enzyme Research, 2011(1), pp.1-17.

Brostow, W., Lu, X. and Osmanson, A. (2018). Nontoxic bio-plasticizers for PVC as replacements for conventional toxic plasticizers. Polymer Testing, 69(1), pp.63-70.

Bule, M., Chaudhary, I., Gao, A. and Chen, S. (2016). Effects of extracellular proteome on wheat straw pretreatment during solid-state fermentation of Phlebia radiata ATCC 64658. International Biodeterioration \& Biodegradation, 109(1), pp.36-44.

Burniol-Figols, A., Varrone, C., Daugaard, A., Le, S., Skiadas, I. and Gavala, H. (2018). Polyhydroxyalkanoates (PHA) production from fermented crude glycerol: Study on the conversion of 1,3-propanediol to PHA in mixed microbial consortia. Water Research, 128(1), pp.255-266. 
Cai, L., Wang, J., Peng, J., Wu, Z. and Tan, X. (2018). Observation of the degradation of three types of plastic pellets exposed to UV irradiation in three different environments. Science of The Total Environment, 628-629(1), pp.740-747.

Changwichan, K., Silalertruksa, T. and Gheewala, S. (2018). Eco-Efficiency Assessment of Bioplastics Production Systems and End-of-Life Options. Sustainability, 10(4), p.952.

Cerrone, F., Davis, R., Kenny, S., Woods, T., O’Donovan, A., Gupta, V., Tuohy, M., Babu, R., O'Kiely, P. and O'Connor, K. (2015). Use of a mannitol rich ensiled grass press juice (EGPJ) as a sole carbon source for polyhydroxyalkanoates (PHAs) production through high cell density cultivation. Bioresource Technology, 191(1), pp.45-52.

Cesário, M., Raposo, R., Almeida, M., van Keulen, F., Ferreira, B., Telo, J. and Fonseca, M. (2014). Production of poly(3-hydroxybutyrate-co-4-hydroxybutyrate) by Burkholderia sacchari using wheat straw hydrolysates and gamma-butyrolactone. International Journal of Biological Macromolecules, 71(1), pp.59-67.

Cesário, M., Raposo, R., de Almeida, M., van Keulen, F., Ferreira, B. and da Fonseca, M. (2014). Enhanced bioproduction of poly-3-hydroxybutyrate from wheat straw lignocellulosic hydrolysates. New Biotechnology, 31(1), pp.104-113.

Chakraborty, P., Gibbons, W. and Muthukumarappan, K. (2009). Conversion of volatile fatty acids into polyhydroxyalkanoate byRalstonia eutropha. Journal of Applied Microbiology, 106(1), pp.1996-2005. 
Chen, Q., Yin, D., Jia, Y., Schiwy, S., Legradi, J., Yang, S. and Hollert, H. (2017). Enhanced uptake of BPA in the presence of nanoplastics can lead to neurotoxic effects in adult zebrafish. Science of The Total Environment, 609(1), pp.1312-1321.

Chen, X., Li, H., Sun, S., Cao, X. and Sun, R. (2018). Co-production of oligosaccharides and fermentable sugar from wheat straw by hydrothermal pretreatment combined with alkaline ethanol extraction. Industrial Crops and Products, 111, pp.78-85.

Chen, Y., Stevens, M., Zhu, Y., Holmes, J. and Xu, H. (2013). Understanding of alkaline pretreatment parameters for corn stover enzymatic saccharification. Biotechnology for Biofuels, 6(8), pp.1-10.

Chen, Y., Wu, C., Zhang, H., Lin, Q., Hong, Y. and Luo, Y. (2013). Empirical estimation of pollution load and contamination levels of phthalate esters in agricultural soils from plastic film mulching in China. Environmental Earth Sciences, 70(1), pp.239-247.

Chen, W., Pen, B., Yu, C. and Hwang, W. (2011). Pretreatment efficiency and structural characterization of rice straw by an integrated process of dilute-acid and steam explosion for bioethanol production. Bioresource Technology, 102(3), pp.2916-2924.

Cho, Y., Park, S. and Han, M. (2015). Di-(2-ethylhexyl)-phthalate induces oxidative stress in human endometrial stromal cells in vitro. Molecular and Cellular Endocrinology, 407(1), pp.917. 
Choi, J., Jung, Y., Hong, N., Hong, S. and Park, J. (2018). Toxicological effects of irregularly shaped and spherical microplastics in a marine teleost, the sheepshead minnow ( Cyprinodon variegatus ). Marine Pollution Bulletin, 129(1), pp.231-240.

Colmenero, A., Barría, C., Broglio, E. and García-Barcelona, S. (2017). Plastic debris straps on threatened blue shark Prionace glauca. Marine Pollution Bulletin, 115(1-2), pp.436-438.

Costa, A., Reul, L., Sousa, F., Ito, E., Carvalho, L. and Canedo, E. (2018). Degradation during processing of vegetable fiber compounds based on PBAT/PHB blends. Polymer Testing, 69(1), pp.266-275.

da Silva, A., Inoue, H., Endo, T., Yano, S. and Bon, E. (2010). Milling pretreatment of sugarcane bagasse and straw for enzymatic hydrolysis and ethanol fermentation. Bioresource Technology, 101(1), pp.7402-7409.

Dahman, Y. and Ugwu, C. (2014). Production of green biodegradable plastics of poly(3hydroxybutyrate) from renewable resources of agricultural residues. Bioprocess and Biosystems Engineering, 37(8), pp.1561-1568.

D'Amico, D., Iglesias Montes, M., Manfredi, L. and Cyras, V. (2016). Fully bio-based and biodegradable polylactic acid/poly(3-hydroxybutirate) blends: Use of a common plasticizer as performance improvement strategy. Polymer Testing, 49(1), pp.22-28.

Darie-Niţă, R., Vasile, C., Irimia, A., Lipşa, R. and Râpă, M. (2015). Evaluation of some ecofriendly plasticizers for PLA films processing. Journal of Applied Polymer Science, 133(13), p.n/a-n/a. 
Davis, R., Kataria, R., Cerrone, F., Woods, T., Kenny, S., O’Donovan, A., Guzik, M., Shaikh, H., Duane, G., Gupta, V., Tuohy, M., Padamatti, R., Casey, E. and O’Connor, K. (2013). Conversion of grass biomass into fermentable sugars and its utilization for medium chain length polyhydroxyalkanoate (mcl-PHA) production by Pseudomonas strains. Bioresource Technology, 150(1), pp.202-209.

de Sá, L., Luís, L. and Guilhermino, L. (2015). Effects of microplastics on juveniles of the common goby (Pomatoschistus microps): Confusion with prey, reduction of the predatory performance and efficiency, and possible influence of developmental conditions. Environmental Pollution, 196(1), pp.359-362.

Debroas, D., Mone, A. and Ter Halle, A. (2017). Plastics in the North Atlantic garbage patch: A boat-microbe for hitchhikers and plastic degraders. Science of The Total Environment, 599600(1), pp.1222-1232.

Desai, M., Ferrini, M., Han, G., Jellyman, J. and Ross, M. (2018). In vivo maternal and in vitro BPA exposure effects on hypothalamic neurogenesis and appetite regulators. Environmental Research, 164, pp.45-52.

Ding, J., Zhang, S., Razanajatovo, R., Zou, H. and Zhu, W. (2018). Accumulation, tissue distribution, and biochemical effects of polystyrene microplastics in the freshwater fish red tilapia (Oreochromis niloticus ). Environmental Pollution, 238(1), pp.1-9. 
Ferreira, L., Donoso-Bravo, A., Nilsen, P., Fdz-Polanco, F. and Pérez-Elvira, S. (2013). Influence of thermal pretreatment on the biochemical methane potential of wheat straw. Bioresource Technology, 143(1), pp.251-257.

Ferreira, L., Donoso-Bravo, A., Nilsen, P., Fdz-Polanco, F. and Pérez-Elvira, S. (2013). Influence of thermal pretreatment on the biochemical methane potential of wheat straw. Bioresource Technology, 143(1), pp.251-257.

Fukui, T., Mukoyama, M., Orita, I. and Nakamura, S. (2014). Enhancement of glycerol utilization ability of Ralstonia eutropha $\mathrm{H} 16$ for production of polyhydroxyalkanoates. Applied Microbiology and Biotechnology, 98(1), pp.7559-7568.

Galletti, G. and Chiavari, G. (1991). Size-exclusion chromatography of lignocellulosics in wheat straw. Journal of Chromatography A, 536(1), pp.303-308.

Gao, C., Xiao, W., Ji, G., Zhang, Y., Cao, Y. and Han, L. (2017). Regularity and mechanism of wheat straw properties change in ball milling process at cellular scale. Bioresource Technology, 241(1), pp.214-219.

Garcia C., Jaldon, Dupeyre, D. and Vignon, M. (1998). Fibres from semi-retted hemp bundles by steam explosion treatment. Biomass and Bioenergy, 14(3), pp.251-260.

Garcia-Garcia, D., Ferri, J., Montanes, N., Lopez-Martinez, J. and Balart, R. (2016). Plasticization effects of epoxidized vegetable oils on mechanical properties of poly(3hydroxybutyrate). Polymer International, 65(10), pp.1157-1164. 
Garcia-Garcia, D., Lopez-Martinez, J., Balart, R., Strömberg, E. and Moriana, R. (2018). Reinforcing capability of cellulose nanocrystals obtained from pine cones in a biodegradable poly(3-hydroxybutyrate)/poly(e-caprolactone) (PHB/PCL) thermoplastic blend. European Polymer Journal, 104(1), pp.10-18.

Garcia-, C., Jaldon, Dupeyre, D. and Vignon, M. (1998). Fibres from semi-retted hemp bundles by steam explosion treatment. Biomass and Bioenergy, 14(3), pp.251-260.

George, M., Mussone, P. and Bressler, D. (2015). Improving the accessibility of hemp fibres using caustic to swell the macrostructure for enzymatic enhancement. Industrial Crops and Products, 67, pp.74-80.

George, M., Mussone, P., Abboud, Z. and Bressler, D. (2014). Characterization of chemically and enzymatically treated hemp fibres using atomic force microscopy and spectroscopy. Applied Surface Science, 314(1), pp.1019-1025.

Getachew, A. and Woldesenbet, F. (2016). Production of biodegradable plastic by polyhydroxybutyrate (PHB) accumulating bacteria using low cost agricultural waste material. BMC Research Notes, 9(509), pp.1-9.

Geyer, R., Jambeck, J. and Law, K. (2017). Production, use, and fate of all plastics ever made. Science Advances, 3(7), pp.1-5.

Giovanoulis, G., Bui, T., Xu, F., Papadopoulou, E., Padilla-Sanchez, J., Covaci, A., Haug, L., Cousins, A., Magnér, J., Cousins, I. and de Wit, C. (2018). Multi-pathway human exposure assessment of phthalate esters and DINCH. Environment International, 112(1), pp.115-126. 
Goonoo, N., Bhaw-Luximon, A., Passanha, P., Esteves, S., Schönherr, H. and Jhurry, D. (2017). Biomineralization potential and cellular response of PHB and PHBV blends with natural anionic polysaccharides. Materials Science and Engineering: C, 76(1), pp.13-24.

Gutiérrez, T. and Alvarez, V. (2017). Eco-friendly films prepared from plantain flour/PCL blends under reactive extrusion conditions using zirconium octanoate as a catalyst. Carbohydrate Polymers, 178(1), pp.260-269.

Guzman Lagunes, F. and Winterburn, J. (2016). Effect of limonene on the heterotrophic growth and polyhydroxybutyrate production by Cupriavidus necator H16. Bioresource Technology, 221(1), pp.336-343

Heinrich, D., Madkour, M., Al-Ghamdi, M., Shabbaj, I. and Steinbüchel, A. (2012). Large scale extraction of poly(3-hydroxybutyrate) from Ralstonia eutropha H16 using sodium hypochlorite. AMB Express, 2(1), p.59.

Hoffman, M. and Hittinger, E. (2017). Inventory and transport of plastic debris in the Laurentian Great Lakes. Marine Pollution Bulletin, 115(1-2), pp.273-281.

Howe, S., Borodinsky, L. and Lyon, R. (1998). Potential exposure to bisphenol a from foodcontact use of epoxy coated cans. Journal of Coatings Technology, 70(2), pp.69-74.

Huang, L., Liu, C., Liu, Y. and Jia, X. (2016). The composition analysis and preliminary cultivation optimization of a PHA-producing microbial consortium with xylose as a sole carbon source. Waste Management, 52(1), pp.77-85. 
Huang, R., Liu, Z., Yuan, S., Yin, H., Dang, Z. and Wu, P. (2017). Worldwide human daily intakes of bisphenol A (BPA) estimated from global urinary concentration data (2000-2016) and its risk analysis. Environmental Pollution, 230(1), pp.143-152.

Huijgen, W., Smit, A., de Wild, P. and den Uil, H. (2012). Fractionation of wheat straw by prehydrolysis, organosolv delignification and enzymatic hydrolysis for production of sugars and lignin. Bioresource Technology, 114(1), pp.389-398.

Huschner, F., Grousseau, E., Brigham, C., Plassmeier, J., Popović, M., Rha, C. and Sinskey, A. (2015). Corrigendum to "Development of a feeding strategy for high cell and PHA density fedbatch fermentation of Ralstonia eutropha H16 from organic acids and their salts" [Process Biochem. 50 (2 (February)) (2015) 165-172]. Process Biochemistry, 50(6), pp.165-172.

IEA (2014). IEA BIOENERGY Task42 BIOREFINING. IEA BioEnergy. Wageningen,: IEA BioEnergy, pp.1-66.

Insomphun, C., Mifune, J., Orita, I., Numata, K., Nakamura, S. and Fukui, T. (2014). Modification of $\beta$-oxidation pathway in Ralstonia eutropha for production of poly(3hydroxybutyrate-co-3-hydroxyhexanoate) from soybean oil. Journal of Bioscience and Bioengineering, 117(2), pp.184-190.

Ishak, K., Annuar, M., Heidelberg, T. and Gumel, A. (2016). Ultrasound-Assisted Rapid Extraction of Bacterial Intracellular Medium-Chain-Length Poly(3-Hydroxyalkanoates) (mclPHAs) in Medium Mixture of Solvent/Marginal Non-solvent. Arabian Journal for Science and Engineering, 41(1), pp.33-44. 
Jaisamut, K., Paulová, L., Patáková, P., Kotúčová, S. and Rychtera, M. (2016). Effect of sodium sulfite on acid pretreatment of wheat straw with respect to its final conversion to ethanol. Biomass and Bioenergy, 95(1), pp.1-7.

Jaisamut, K., Paulová, L., Patáková, P., Rychtera, M. and Melzoch, K. (2013). Optimization of alkali pretreatment of wheat straw to be used as substrate for biofuels production \&nbsp;. Plant, Soil and Environment, 59(12), pp.537-542.

Jalal, N., Surendranath, A., Pathak, J., Yu, S. and Chung, C. (2018). Bisphenol A (BPA) the mighty and the mutagenic. Toxicology Reports, 5(1), pp.76-84.

Jambeck, J., Geyer, R., Wilcox, C., Siegler, T., Perryman, M., Andrady, A., Narayan, R. and Law, K. (2015). Plastic waste inputs from land into the ocean. Science, 347(6223), pp.768-771.

Jeun, J., Lee, B., Lee, J., Kang, P. and Park, J. (2015). An irradiation-alkaline pretreatment of kenaf core for improving the sugar yield. Renewable Energy, 79(1), pp.51-55.

John, M., Anandjiwala, R., Pothan, L. and Thomas, S. (2007). Cellulosic fibre-reinforced green composites. Composite Interfaces, 14(7-9), pp.733-751.

Jovanović, B. (2017). Ingestion of microplastics by fish and its potential consequences from a physical perspective. Integrated Environmental Assessment and Management, 13(3), pp.510515. 
Kabir, M., Wang, H., Lau, K. and Cardona, F. (2013). Effects of chemical treatments on hemp fibre structure. Applied Surface Science, 276(1), pp.13-23.

Kang, J. and Kondo, F. (2002). Determination of bisphenol A in canned pet foods. Research in Veterinary Science, 73(2), pp.177-182.

Kaur, G. and Roy, L. (2015). Strategies for Large-scale Production of Polyhydroxyalkanoates. Chemical and Biochemical Engineering Quarterly, 29(2), pp.157-172.

Koestel, Z., Backus, R., Tsuruta, K., Spollen, W., Johnson, S., Javurek, A., Ellersieck, M., Wiedmeyer, C., Kannan, K., Xue, J., Bivens, N., Givan, S. and Rosenfeld, C. (2017). Bisphenol A (BPA) in the serum of pet dogs following short-term consumption of canned dog food and potential health consequences of exposure to BPA. Science of The Total Environment, 579(1), pp.1804-1814.

Kosseva, M. and Rusbandi, E. (2018). Trends in the biomanufacture of polyhydroxyalkanoates with focus on downstream processing. International Journal of Biological Macromolecules, 107(1), pp.762-778.

Kreuger, E., Sipos, B., Zacchi, G., Svensson, S. and Björnsson, L. (2011). Bioconversion of industrial hemp to ethanol and methane: The benefits of steam pretreatment and co-production. Bioresource Technology, 102(3), pp.3457-3465.

Kuglarz, M., Alvarado-Morales, M., Karakashev, D. and Angelidaki, I. (2016). Integrated production of cellulosic bioethanol and succinic acid from industrial hemp in a biorefinery concept. Bioresource Technology, 200(1), pp.639-647. 
Kumar, P., Ray, S. and Kalia, V. (2016). Production of co-polymers of polyhydroxyalkanoates by regulating the hydrolysis of biowastes. Bioresource Technology, 200(1), pp.413-419.

Kunasundari, B. and Sudesh, K. (2011). Isolation and recovery of microbial polyhydroxyalkanoates. Express Polymer Letters, 5(7), pp.620-634

Kupski, L., Telles, A., Gonçalves, L., Nora, N. and Furlong, E. (2018). Recovery of functional compounds from lignocellulosic material: An innovative enzymatic approach. Food Bioscience, 22(1), pp.26-31.

Landon-Lane, M. (2018). Corporate social responsibility in marine plastic debris governance. Marine Pollution Bulletin, 127(1), pp.310-319.

Le, D., Sørensen, H., Knudsen, N., Schjoerring, J. and Meyer, A. (2014). Biorefining of wheat straw: accounting for the distribution of mineral elements in pretreated biomass by an extended pretreatment-severity equation. Biotechnology for Biofuels, 7(1), pp.1-13.

Lee, H., Jeon, B. and Oh, M. (2016). Microbial production of ethanol from acetate by engineered Ralstonia eutropha. Biotechnology and Bioprocess Engineering, 21(1), pp.402-407.

Leslie, H. (2015). Plastic in Cosemtics : Are we polluting the environment through our personal care?. Nairobi,: IVM instsitue for Environment Studies, pp.1-38.

Lin, Y. and Chen, P. (2017). Development of polyhydroxybutyrate biosynthesis in Bacillus subtilis with combination of PHB-associated genes derived from Ralstonia eutropha and Bacillus megaterium. Journal of the Taiwan Institute of Chemical Engineers, 79(1), pp.110-115. 
Lin, Z., Wang, L., Jia, Y., Zhang, Y., Dong, Q. and Huang, C. (2017). A Study on Environmental Bisphenol A Pollution in Plastics Industry Areas. Water, Air, \& Soil Pollution, 228(3), pp.1-9.

Liu, J., Wattar, N., Field, C., Dinu, I., Dewey, D. and Martin, J. (2018). Exposure and dietary sources of bisphenol A (BPA) and BPA-alternatives among mothers in the APrON cohort study. Environment International, 119(1), pp.319-326.

Liu, L., Yu, J., Cheng, L. and Yang, X. (2009). Biodegradability of poly(butylene succinate) (PBS) composite reinforced with jute fibre. Polymer Degradation and Stability, 94(1), pp.90-94.

Liu, X., Zicari, S., Liu, G., Li, Y. and Zhang, R. (2015). Pretreatment of wheat straw with potassium hydroxide for increasing enzymatic and microbial degradability. Bioresource Technology, 185(1), pp.150-157.

Ma, P., Xu, P., Chen, M., Dong, W., Cai, X., Schmit, P., Spoelstra, A. and Lemstra, P. (2014). Structure-property relationships of reactively compatibilized PHB/EVA/starch blends. Carbohydrate Polymers, 108(1), pp.299-306.

Macagnan, K., Alves, M., Rodrigues, A., Furlan, L., da Silva Rodrigues, R., Diaz de Oliveira, P., Vendruscolo, C. and da Silveira Moreira, A. (2017). Complete factorial design to adjust pH and sugar concentrations in the inoculum phase of Ralstonia solanacearum to optimize $\mathrm{P}(3 \mathrm{HB})$ production. PLOS ONE, 12(7), pp.1-14.

Macagnan, K., Rodrigues, A., Alves, M., Furlan, L., Kesserlingh, S., Moura, A., de Oliveira, P., McBride, A., Moreira, A. and Vendruscolo, C. (2016). Simplified recovery process of Ralstonia 
solanacearum-synthesized polyhydroxyalkanoates via chemical extraction complemented by liquid-liquid phase separation. Química Nova, 40(2), pp.125-130.

Machtinger, R., Gaskins, A., Racowsky, C., Mansur, A., Adir, M., Baccarelli, A., Calafat, A. and Hauser, R. (2018). Urinary concentrations of biomarkers of phthalates and phthalate alternatives and IVF outcomes. Environment International, 111(1), pp.23-31.

Mancini, G., Papirio, S., Lens, P. and Esposito, G. (2018). Increased biogas production from wheat straw by chemical pretreatments. Renewable Energy, 119(1), pp.608-614.

Martín, C., Klinke, H. and Thomsen, A. (2007). Wet oxidation as a pretreatment method for enhancing the enzymatic convertibility of sugarcane bagasse. Enzyme and Microbial Technology, 40(3), pp.426-432.

Martín-Sampedro, R., Rahikainen, J., Johansson, L., Marjamaa, K., Laine, J., Kruus, K. and Rojas, O. (2013). Preferential Adsorption and Activity of Monocomponent Cellulases on Lignocellulose Thin Films with Varying Lignin Content. Biomacromolecules, 14(4), pp.12311239.

Modi, S., Koelling, K. and Vodovotz, Y. (2011). Assessment of PHB with varying hydroxyvalerate content for potential packaging applications. European Polymer Journal, 47(2), pp.179-186.

Mousavioun, P., Halley, P. and Doherty, W. (2013). Thermophysical properties and rheology of PHB/lignin blends. Industrial Crops and Products, 50(1), pp.270-275. 
Mozumder, M., De Wever, H., Volcke, E. and Garcia-Gonzalez, L. (2014). A robust fed-batch feeding strategy independent of the carbon source for optimal polyhydroxybutyrate production. Process Biochemistry, 49(1), pp.365-373.

Mumtaz, T., Yahaya, N., Abd-Aziz, S., Abdul Rahman, N., Yee, P., Shirai, Y. and Hassan, M. (2010). Turning waste to wealth-biodegradable plastics polyhydroxyalkanoates from palm oil mill effluent - a Malaysian perspective. Journal of Cleaner Production, 18(1), pp.1393-1402.

Narayanan, A., Sajeev Kumar, V. and Ramana, K. (2013). Production and Characterization of Poly (3-Hydroxybutyrate-co-3-Hydroxyvalerate) from Bacillus mycoides DFC1 Using Rice Husk Hydrolyzate. Waste and Biomass Valorization, 5(1), pp.109-118.

Noda, I., Green, P., Satkowski, M. and Schechtman, L. (2005). Preparation and Properties of a Novel Class of Polyhydroxyalkanoate Copolymers†े. Biomacromolecules, 6(2), pp.580-586

Oehmen, A., Pinto, F., Silva, V., Albuquerque, M. and Reis, M. (2014). The impact of pH control on the volumetric productivity of mixed culture PHA production from fermented molasses. Engineering in Life Sciences, 14(2), pp.143-152.

Pakarinen, A., Zhang, J., Brock, T., Maijala, P. and Viikari, L. (2012). Enzymatic accessibility of fiber hemp is enhanced by enzymatic or chemical removal of pectin. Bioresource Technology, 107(1), pp.275-281.

Park, N., Kim, H., Koo, B., Yeo, H. and Choi, I. (2010). Organosolv pretreatment with various catalysts for enhancing enzymatic hydrolysis of pitch pine (Pinus rigida). Bioresource Technology, 101(18), pp.7046-7053. 
PlasticEurope (2018). Plastics - the Facts 2017. PlasticEurope, pp.1-44.

Przybysz, M., Marć, M., Klein, M., Saeb, M. and Formela, K. (2018). Structural, mechanical and thermal behavior assessments of PCL/PHB blends reactively compatibilized with organic peroxides. Polymer Testing, 67(1), pp.513-521.

Rajput, A., Zeshan and Visvanathan, C. (2018). Effect of thermal pretreatment on chemical composition, physical structure and biogas production kinetics of wheat straw. Journal of Environmental Management, 221(1), pp.45-52.

Reddy, N. and Yang, Y. (2005). Biofibers from agricultural byproducts for industrial applications. Trends in Biotechnology, 23(1), pp.22-27.

Riedel, S., Jahns, S., Koenig, S., Bock, M., Brigham, C., Bader, J. and Stahl, U. (2015). Polyhydroxyalkanoates production with Ralstonia eutropha from low quality waste animal fats. Journal of Biotechnology, 214(1), pp.119-127.

Romaní, A., Tomaz, P., Garrote, G., Teixeira, J. and Domingues, L. (2016). Combined alkali and hydrothermal pretreatments for oat straw valorization within a biorefinery concept. Bioresource Technology, 220(1), pp.323-332.

Sánchez-Safont, E., Aldureid, A., Lagarón, J., Gámez-Pérez, J. and Cabedo, L. (2018). Biocomposites of different lignocellulosic wastes for sustainable food packaging applications. Composites Part B: Engineering, 145(1), pp.215-225. 
Saratale, G. and Oh, M. (2015). Characterization of poly-3-hydroxybutyrate (PHB) produced from Ralstonia eutropha using an alkali-pretreated biomass feedstock. International Journal of Biological Macromolecules, 80(1), pp.627-635.

Saratale, G. and Oh, M. (2015). Characterization of poly-3-hydroxybutyrate (PHB) produced from Ralstonia eutropha using an alkali-pretreated biomass feedstock. International Journal of Biological Macromolecules, 80(1), pp.627-635.

Sindhu, R., Silviya, N., Binod, P. and Pandey, A. (2013). Pentose-rich hydrolysate from acid pretreated rice straw as a carbon source for the production of poly-3-hydroxybutyrate. Biochemical Engineering Journal, 78(1), pp.67-72.

Scaffaro, R., Lopresti, F. and Botta, L. (2018). PLA based biocomposites reinforced with Posidonia oceanica leaves. Composites Part B: Engineering, 139(1), pp.1-11.

Schluttenhofer, C. and Yuan, L. (2017). Challenges towards Revitalizing Hemp: A Multifaceted Crop. Trends in Plant Science, 22(11), pp.917-929.

Sluiter, J. and Sluiter, A. (2011). Laboratory Analytical Procedure (LAP) Review and Integration: Pretreated Slurries. Summative Mass Closure. Golden: National Renewable Energy Laboratory, pp.1-12.

Sluiter, A., Sluiter, J., Wolfrum, E., Reed, M., Ness, R., Scarlata, C. and Henry, J. (2016). Improved methods for the determination of drying conditions and fraction insoluble solids (FIS) in biomass pretreatment slurry. Biomass and Bioenergy, 91, pp.234-242. 
Sun, R., Lawther, J. and Banks, W. (1995). Influence of alkaline pre-treatments on the cell wall components of wheat straw. Industrial Crops and Products, 4(1), pp.127-145.

Sun, S., Liu, P., Ji, N., Hou, H. and Dong, H. (2018). Effects of various cross-linking agents on the physicochemical properties of starch/PHA composite films produced by extrusion blowing. Food Hydrocolloids, 77(1), pp.964-975.

Suwannasing, W., Imai, T. and Kaewkannetra, P. (2015). Cost-effective defined medium for the production of polyhydroxyalkanoates using agricultural raw materials. Bioresource Technology, 194(1), pp.67-74.

Syed, K. and Dahman, Y. (2015). Novel clostridial fusants in comparison with co-cultured counterpart species for enhanced production of biobutanol using green renewable and sustainable feedstock. Bioprocess and Biosystems Engineering, 38(11), pp.2249-2262.

Taguchi, S., Nakamura, H., Kichise, T., Tsuge, T., Yamato, I. and Doi, Y. (2003). Production of polyhydroxyalkanoate (PHA) from renewable carbon sources in recombinant Ralstonia eutropha using mutants of original PHA synthase. Biochemical Engineering Journal, 16(2), pp.107-113.

Templeton, D., Quinn, M., Van Wychen, S., Hyman, D. and Laurens, L. (2012). Separation and quantification of microalgal carbohydrates. Journal of Chromatography A, 1270, pp.225-234.

Villano, M., Beccari, M., Dionisi, D., Lampis, S., Miccheli, A., Vallini, G. and Majone, M. (2010). Effect of $\mathrm{pH}$ on the production of bacterial polyhydroxyalkanoates by mixed cultures enriched under periodic feeding. Process Biochemistry, 45(5), pp.714-723. 
Villano, M., Valentino, F., Barbetta, A., Martino, L., Scandola, M. and Majone, M. (2014).

Polyhydroxyalkanoates production with mixed microbial cultures: from culture selection to polymer recovery in a high-rate continuous process. New Biotechnology, 31(4), pp.289-296.

Wan, W., Zhang, S., Huang, H. and Wu, T. (2016). Occurrence and distribution of organophosphorus esters in soils and wheat plants in a plastic waste treatment area in China. Environmental Pollution, 214, pp.349-353.

Wang, B., Shen, X., Wen, J., Xiao, L. and Sun, R. (2017). Evaluation of organosolv pretreatment on the structural characteristics of lignin polymers and follow-up enzymatic hydrolysis of the substrates from Eucalyptus wood. International Journal of Biological Macromolecules, 97(1), pp.447-459.

Wang, L., Liu, M., Tao, W., Zhang, W., Wang, L., Shi, X., Lu, X. and Li, X. (2018). Pollution characteristics and health risk assessment of phthalate esters in urban soil in the typical semi-arid city of Xi'an, Northwest China. Chemosphere, 191(1), pp.467-476.

Wang, Y., Zhou, B., Chen, Y., Liu, C., Huang, L., Liao, J., Hu, X., Lu, W., Zeng, Q. and Pan, A. (2018). Thyroid function, phthalate exposure and semen quality: Exploring associations and mediation effects in reproductive-aged men. Environment International, 116(1), pp.278-285.

Wu, X., Huang, C., Zhai, S., Liang, C., Huang, C., Lai, C. and Yong, Q. (2018). Improving enzymatic hydrolysis efficiency of wheat straw through sequential autohydrolysis and alkaline post-extraction. Bioresource Technology, 251(1), pp.374-380. 
Wunna, K., Nakasaki, K., Auresenia, J., Abella, L. and Gaspillo, P. (2017). Effect of Alkali Pretreatment on Removal of Lignin from Sugarcane Bagasse. Effect of Alkali Pretreatment on Removal of Lignin from Sugarcane Bagasse, 57(1), pp.1831-1836.

Xie, C., Gong, W., Yang, Q., Zhu, Z., Yan, L., Hu, Z. and Peng, Y. (2017). White-rot fungi pretreatment combined with alkaline/oxidative pretreatment to improve enzymatic saccharification of industrial hemp. Bioresource Technology, 243, pp.188-195.

Yang, Y., Brigham, C., Willis, L., Rha, C. and Sinskey, A. (2011). Improved detergent-based recovery of polyhydroxyalkanoates (PHAs). Biotechnology Letters, 33(5), pp.937-942.

Yuan, Z., Wen, Y. and Li, G. (2018). Production of bioethanol and value added compounds from wheat straw through combined alkaline/alkaline-peroxide pretreatment. Bioresource Technology, 259(1), pp.228-236.

Yuan, Z., Wen, Y., Kapu, N. and Beatson, R. (2018). Evaluation of an organosolv-based biorefinery process to fractionate wheat straw into ethanol and co-products. Industrial Crops and Products, 121(1), pp.294-302.

Zbyszewski, M. and Corcoran, P. (2011). Distribution and Degradation of Fresh Water Plastic Particles Along the Beaches of Lake Huron, Canada. Water, Air, \& Soil Pollution, 220(1), pp.365-372.

Zhang, Y., Berson, E., Sarkanen, S. and Dale, B. (2009). Sessions 3 and 8: Pretreatment and Biomass Recalcitrance: Fundamentals and Progress. Applied Biochemistry and Biotechnology, 153(1-3), pp.80-83. 
Zhang, J., Pakarinen, A. and Viikari, L. (2013). Synergy between cellulases and pectinases in the hydrolysis of hemp. Bioresource Technology, 129(1), pp.302-307.

Zhang, M. and Thomas, N. (2011). Blending polylactic acid with polyhydroxybutyrate: The effect on thermal, mechanical, and biodegradation properties. Advances in Polymer Technology, 30(2), pp.67-79.

Zhao, Y., Wang, Y., Zhu, J., Ragauskas, A. and Deng, Y. (2008). Enhanced enzymatic hydrolysis of spruce by alkaline pretreatment at low temperature. Biotechnology and Bioengineering, 99(6), pp.1320-1328.

Zhou, X., Zhou, X., Tang, X. and Xu, Y. (2018). Process for calcium xylonate production as a concrete admixture derived from in-situ fermentation of wheat straw pre-hydrolysate.

Bioresource Technology, 261(1), pp.288-293.

Zhu, S., Huang, W., Huang, W., Wang, K., Chen, Q. and Wu, Y. (2015). Coproduction of xylose, lignosulfonate and ethanol from wheat straw. Bioresource Technology, 185(1), pp.234239.

Zubir, N., Sam, S., Zulkepli, N. and Omar, M. (2017). The effect of rice straw particulate loading and polyethylene glycol as plasticizer on the properties of polylactic acid/polyhydroxybutyratevalerate blends 